EDUARDA SOFIA LOPES COSTA

\title{
ANTICANCER EFFECTS OF THE SEAWEED COMPOUNDS FUCOXANTHIN AND PHLOROGLUCINOL, ALONE AND IN COMBINATION WITH 5-FLUOROURACIL IN COLON CELLS
}

Dissertação de Candidatura ao grau de Mestre em Ciências do Mar - Recursos Marinhos submetida ao Instituto de Ciências Biomédicas de Abel Salazar da Universidade do Porto

Orientadora - Doutora Alice Fernanda Abreu Ramos Categoria - Investigadora Post-Doc Afiliação - Centro Interdisciplinar de Investigação Marinha e Ambiental

Coorientador - Professor Doutor Eduardo Jorge Sousa Rocha Categoria - Professor Catedrático Afiliação - Instituto de Ciências Biomédicas Abel Salazar 


\section{AKNOWLEDGMENTS}

I would like to thank:

Doctor Alice Ramos, my supervisor, for all the help, support, and affection you gave me. Your support during this stage of my academic life was outstanding and extended far beyond the academy. Without your working ability, scientific knowledge and constant presence this thesis would not be possible.

My co-supervisor, Professor Doctor Eduardo Rocha, a science enthusiast who is able to inspire people, for giving me the opportunity to work in this project and to have integrated a wonderful research team.

Professor Doctor Daniela Gargiulo, for your friendship and for her wise guidance.

All my laboratory colleagues, especially Mariana Abreu and Diana Pádua.

My co-worker, Sofia Fernandes.

And especially I would like to thank my family.

This work was partially funded by the ICBAS and by the project MARBIOTECH (reference NORTE-07-0124-FEDER-000047), co-financed by the North Portugal Regional Operational Programme (ON.2 - O Novo Norte), under the National Strategic Reference Framework (NSRF), through the European Regional Development Fund (ERDF).
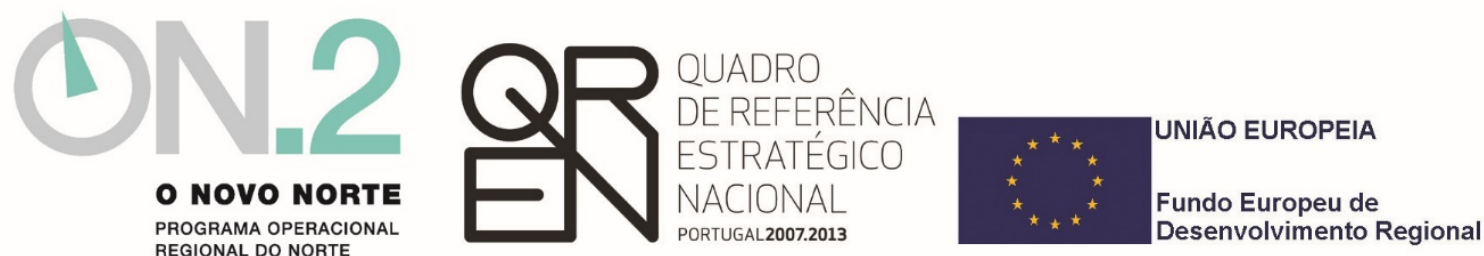


\section{ABSTRACT}

On a global scale, colorectal cancer is considered to be the third most common, and the second most common cause of deaths related with cancer both in men and women. The incidence of colorectal cancer cases has been rising at an alarming rate, particularly in regions with a western lifestyle.

Currently, treatment for colorectal cancer involves the combination of surgery with chemotherapy, by administration of cytotoxic drugs and radiation. 5-fluorouracil (5$\mathrm{Fu}$ ), an antimetabolite, is one of the most commonly used cytotoxic drugs in colorectal treatment. Unfortunately, resistance to 5-Fu may emerge during treatment due to several biological mechanisms, namely over expression of thymidylate synthase (TS) and alterations in the apoptotic pathway. One of the strategies to overcome drug resistance is the combination with other drugs and/or natural compounds.

The chemical and biological diversity of the marine environment is incalculable, making this a reservoir of natural bioactive compounds. Many of these products exhibit structural and chemical characteristics that are not found in natural terrestrial compounds. With this in mind, the research of new natural products with high efficacy against tumour cells and no apparent cytotoxicity against normal cells has gained a prominent place in the scientific community. Marine algae are a magnificent source of bioactive compounds which demonstrate a broad range of biological activities such as antioxidant, antimicrobial, anti-inflammatory, and anticancer activities. The biological activities of fucoxanthin, a marine carotenoid, and phloroglucinol, a polyphenolic compound, have been explored in diverse studies, including cytotoxic effects against cancer cell lines.

In the present study, the anticancer effects of fucoxanthin and phloroglucinol alone or combined with 5-Fu were assessed on two colorectal cancer cell lines (HCT116 and HT-29) resorting to anti-proliferative, apoptotic, and genotoxic assays. Also, to assess the specificity of the anticancer effects, a normal colon cell line (CCD-Co18) was also tested. Our results showed that $5-\mathrm{Fu}$ decreased cell viability in a dosedependent manner and induced DNA damage in both cell lines, with HCT-116 cells presenting increased sensitivity to 5-Fu. Furthermore, fucoxanthin decreased cell viability more efficiently than $5-\mathrm{Fu}$ alone and when in co-incubation it enhanced the cytotoxic effect of $5-\mathrm{Fu}$ in the cancer cell line, without toxic effects to normal cells, which could be a promising alternative for resistant colorectal cancer cell lines. 
Phloroglucinol alone also decreased cell viability and in combination increased the sensitivity to $5-\mathrm{Fu}$ in both cancer cell lines, especially in the p53 mutant HT-29 cancer cell line. Nonetheless, at lower concentrations phloroglucinol inhibits the effects of 5-Fu in HCT-116 cells, which is not a desired effect during a cancer treatment.

Both natural compounds, fucoxanthin and phloroglucinol enhance the efficacy of $5-\mathrm{Fu}$ in certain conditions. However, further studies are required to clarify the mechanisms involved in order to become a possible strategy for some cases of 5-Furesistant colon cancer. 


\section{RESUMO}

À escala global, o cancro do coloretal é considerado o terceiro tipo de tumor maligno mais comum, e o segundo responsável pelo maior número de mortes relacionadas com o cancro, tanto em homens como em mulheres. Assistimos a um aumento na incidência de casos de cancro coloretal, de uma forma alarmante, principalmente em regiões com um estilo de vida caraterístico de países desenvolvidos.

Atualmente, o tratamento para o cancro coloretal passa pela combinação de cirurgia com quimioterapia, através da administração de fármacos citotóxicos e do uso de radiação. O 5-fluorouracilo (5-Fu), um anti-metabolito, é um dos compostos citotóxicos mais utilizados no tratamento do cancro coloretal. Infelizmente, durante o tratamento com $5-\mathrm{Fu}$ poderá surgir resistência ao mesmo devido a diversos mecanismos biológicos, nomeadamente expressão elevada da timidilato sintase e alterações na via apoptótica. A combinação com outras fármacos e/ou com compostos naturais é uma das estratégias utilizadas para ultrapassar a resistência a fármacos.

A diversidade química e biológica do ambiente marinho é incalculável, tornandoo um reservatório de compostos naturais bioativos. Muitas destas moléculas exibem caraterísticas estruturais e químicas que não são encontradas nos compostos naturais terrestres. Tendo isto em consideração, a pesquisa de novos produtos naturais com elevada eficiência contra células tumorais e aparentemente sem citotoxicidade contra células normais têm ganho um lugar de destaque dentro da comunidade científica. As algas marinhas são uma fonte magnífica de compostos bioativos que demonstram uma ação vasta de atividades biológicas, entre as quais atividade antioxidante, antimicrobiana, anti-inflamatória e antitumoral. As atividades biológicas da fucoxantina, um "carotenóide marinho", e do floroglucinol, um composto fenólico, que também pode ter origem em organismos marinhos (em particular em algas castanhas), têm sido exploradas em diversos estudos, inclusive os seus efeitos citotóxicos em linhas celulares de cancro.

No presente estudo foram aferidos os efeitos antitumorais da fucoxantina e do floroglucinol, isolados ou em combinação com o 5-Fu, em duas linhas celulares de cancro coloretal (HCT-116 e HT-29) recorrendo a ensaios anti-proliferativos, apoptóticos e de genotoxicidade. A especificidade do efeito antitumoral foi também avaliada utilizando uma linha celular normal de colon (CCD-Co18). Os nossos 
resultados mostraram que o $5-\mathrm{Fu}$, nas duas linhas celulares de cancro testadas, diminuiu a viabilidade celular de uma forma dose-dependente com a capacidade de induzir danos no DNA, sendo as células HCT-116 mais sensíveis ao 5-Fu. Além disso, a fucoxantina diminuiu a viabilidade celular mais eficientemente do que o $5-\mathrm{Fu}$ isolado e quando em co-incubação potenciou o efeito citotóxico do mesmo, sem citotoxicidade para as células normais, tornando-se uma alternativa promissora a ser utilizada em linhas celulares resistentes. O floroglucinol isolado diminuiu também a viabilidade celular e em co-incubação aumentou a sensibilidade de ambas as linhas celulares para o 5-Fu, especialmente da linha celular HT-29 com p53 mutante. Contudo, em concentrações mais baixas inibiu o efeito do 5-Fu nas células HCT-116, condição que não é pretendida durante um tratamento oncológico.

Ambos os compostos naturais, fucoxantina e floroglucinol em certas condições potenciam a eficiência do 5-Fu. Contudo, é necessário a realização de mais estudos de modo a clarificar os mecanismos envolvidos e assim tornar-se numa possível estratégia terapêutica para certos casos de cancro do coloretal resistentes a 5-Fu. 


\section{TABLE OF CONTENTS}

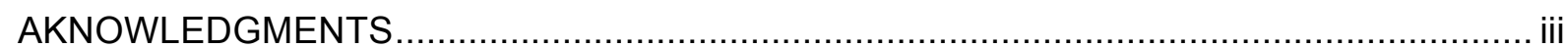

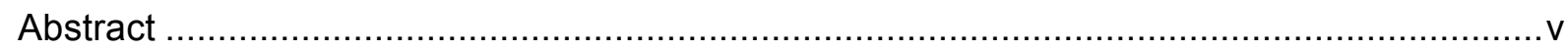

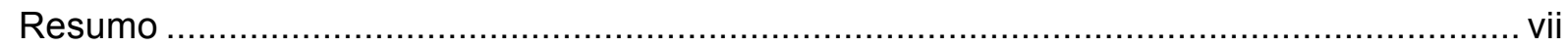

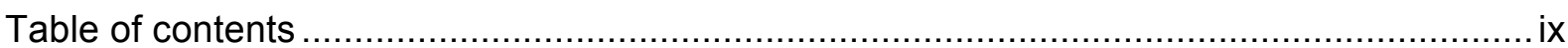

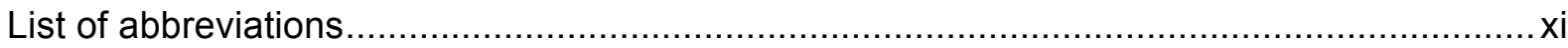

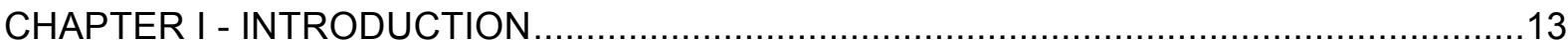

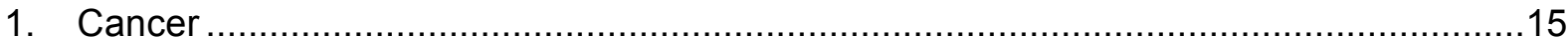

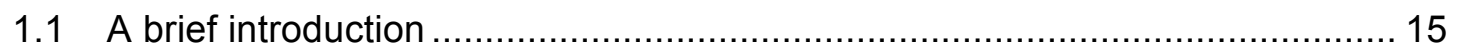

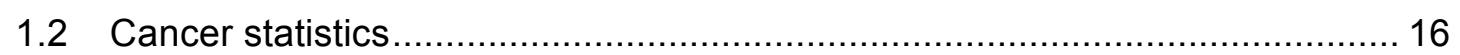

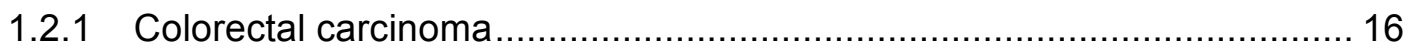

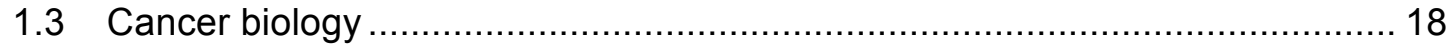

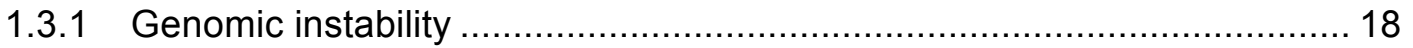

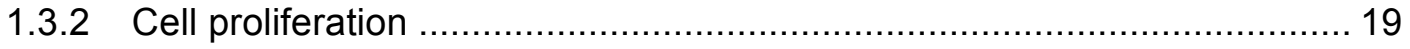

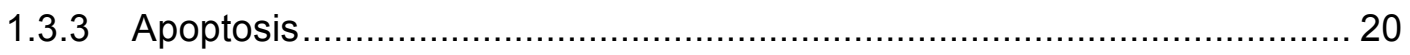

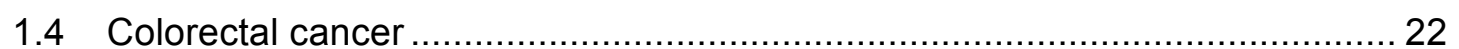

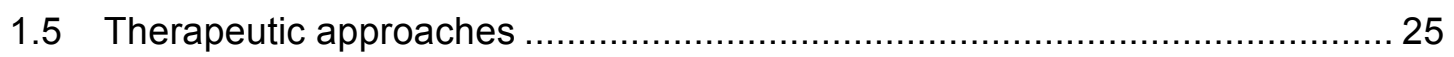

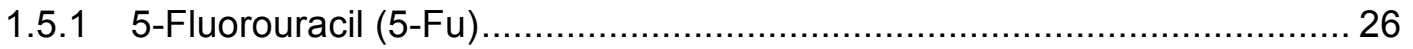

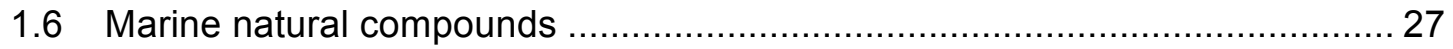

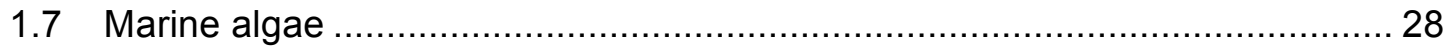

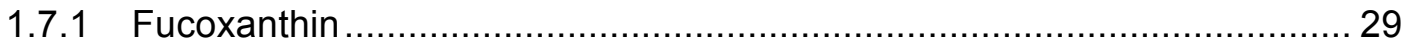

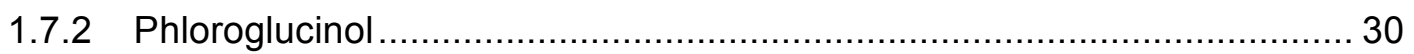

1.8 Methodologies available to screen anticancer activity ................................ 31

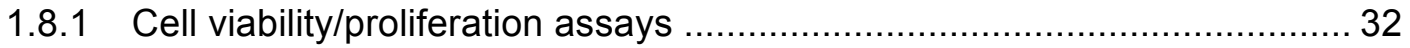

1.9 Evaluation of the possible action mechanisms …...................................... 33

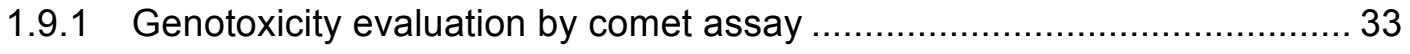

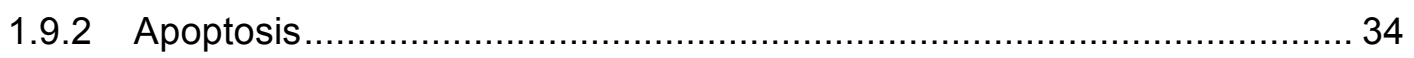

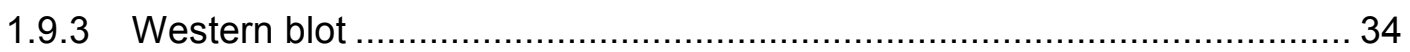

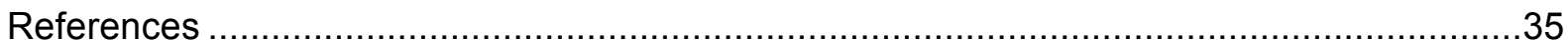


CHAPTER II - ANTICANCER EFFECTS OF THE SEAWEED COMPOUNDS FUCOXANTHIN AND PHLOROGLUCINOL, ALONE AND IN COMBINATION WITH 5-

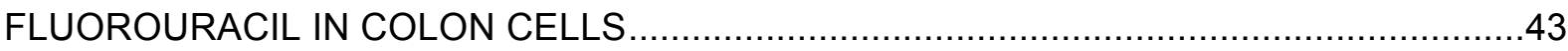

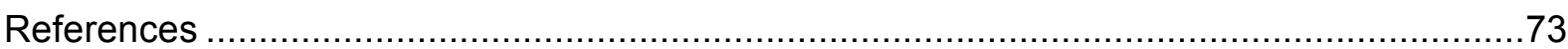

CHAPTER III - CONCLUSIONS AND FUTURE PERSPECTIVES .....................................77

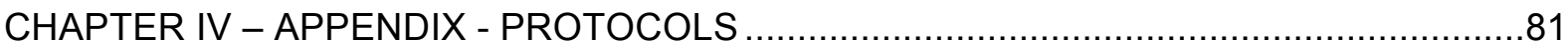




\section{LIST OF ABBREVIATIONS}

5 -Fu - 5-fluorouracil

ACE - Angiotensin l-converting enzyme

APAF1 - Apoptotic protease activating factor 1

APC - Adenomatous polyposis coli

BCA - Bicinchoninic Acid

BRCA - Breast cancer gene

BrdU - Bromodeoxyuridine

CD-DST - collagen gel droplet-embedded culture drug sensitivity test

CIMP - CpG island methylator phenotype

CIN - Chromosomal instability

DAPI - 4', 6-diamidino-2-phenylindole

DISC - Death-inducing signaling complex

DMEM - Dulbecco's Modified Eagle Medium

DMSO - Dimethyl sulfoxide

DNA - Deoxyribonucleic acid

EDTA - Ethylenediaminetetraacetic acid

EGFR - Epidermal growth factor receptor

EMT - Epithelial-mesenchymal transition

ET-743 - Trabectedin

FADD - Fas-associated death domain protein

FBS - Fetal Bovine Serum

FdUMP - Fluorodexoyuridine monophosphate

FdUTP - Fluorodeoxyuridine triphosphate

FUTP - Fluorouridine triphosphate

FOBT - Fecal occult blood test 
HCT-116 - Human colorectal carcinoma cell line

HEPES - N-(2-hydroxyethyl)piperazine-N'-(2-ethanesulfonic acid)

HNPCC - Hereditary Non-Polyposis Colorectal Cancer

HT-29 - Human colon adenocarcinoma cell line

IGF-1 - Insulin-like growth factor-1

$\mathrm{LOH}$ - Loss of heterozygosity

MAPK - Mitogen-activated protein kinase

MSI - Microsatellite instability

mTOR - Mammalian target of rapamycin

MTT - 3-(4,5-dimethylthiazol-2-yl)-2,5-diphenyltetrazolium bromide

$\mathrm{NaCl}$ - Sodium Chloride

PI3K - Phosphatidylinositol 3-kinase

PMSF - Phenylmethanesulfonylfluoride

PBS - Phosphate buffer saline

PS - Phosphatidylserine

RIPA - Radioimmunoprecipation assay

RPMI - Roswell Park Memorial Institute

TKRs - Tyrosine kinase receptors

TNF- $\alpha$ - Tumour necrosis factor- $\alpha$

TNFR1 - Tumour necrosis factor receptor 1

TP53 - Tumour Protein p53 gene

TS - Thymidylate synthase

VEGF - Vascular endothelial growth factor 
CHAPTER I - INTRODUCTION 


\section{CANCER}

\subsection{A brief introduction}

Cancer is the general name for a group of diseases associated to an uncontrolled cell growth and invasiveness. In fact, more than a hundred different types of cancer have been described (Hanahan \& Weinberg, 2000).

There is a general assumption that cancer is a modern age disease. However, that is not entirely true since there are early descriptions of cancerous lesions reported in an ancient Egyptian textbook on trauma surgery (3000 BC). This textbook is known as the Edwin Smith Papyrus and described eight cases of breast tumours (Hajdu, 2011). However, the origin of the word "cancer" is attributed to Hippocrates (460-370 $\mathrm{BC}$ ) that used the terms carcinos and carcinoma to report non-ulcer forming and ulcerforming tumours (Sudhakar, 2010).

Generally, the growth of a cancer cell is different from the normal cell. While a normal cell grows and eventually dies at one point, cancer cells can avoid death and continue to grow and form new abnormal cells (Fig. 1). Another aspect that distinguishes a cancer cell from a normal cell is its ability to invade other tissues, where they are able to proliferate (Cooper, 2000).

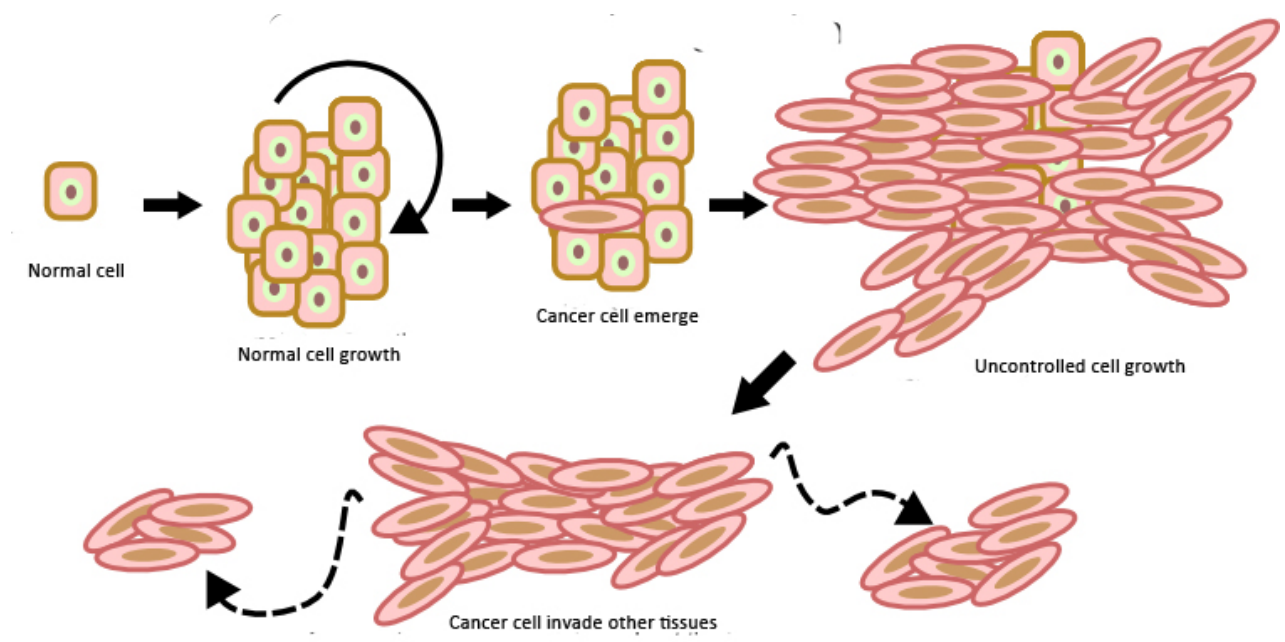

Figure 1 - Cancer cell growth.

Adapted from: http://www.unc.edu/depts/our/hhmi/hh-

mift_learning_modules/cancermodule/pages/cancer.html 
There are two types of risk factors in cancer, the external factors, representing the cause of $90-95 \%$ off all cancers, and internal factors. They can act together, or in sequence, in order to start or to promote a carcinogenic condition. Alcohol consumption, smoking, eating habits, physical inactivity, environmental pollution are examples of external factors (Jemal et al., 2011). Hormonal dysfunctions, immune condition of an individual and mutations count as internal factors (Anand et al., 2008).

\subsection{Cancer statistics}

Over the past decades, a drastic increase in cancer cases in developed and developing countries has been witnessed. Cancer is accountable for causing more deaths than AIDS, tuberculosis and malaria all together (American Society Cancer, 2011).

According to Globocan project, that provides contemporary estimates of incidence, mortality and prevalence from the major types of cancer, there were 14.1 million new cases of cancer in 2012. In the same year, the number of deaths due to cancer was 8.2 million and it is estimated that 32.6 million people have cancer (Ferlay et al., 2015).

The most common cancer worldwide in 2012 was lung cancer, contributing to $13 \%$ of the total number of new cases diagnosed, followed by breast cancer (women only). Colorectal cancer was the third most common cancer with nearly 1.4 million of new cases (Globocan, 2012).

\subsubsection{Colorectal carcinoma}

Colorectal cancer is considered one of the major causes of morbidity and mortality on a global scale. It affects men and women in the same proportion, representing $9.4 \%$ in men and $10.1 \%$ in women off all incident cancers (Haggar \& Boushey, 2009).

In terms of geographic incidence, colorectal cancer is mainly a condition of developed countries that counts with $54 \%$ of colorectal cancer cases. Oceania and Europe have the highest incidence and Africa and Asia the lowest (Fig. 2) (Globocan, 2012). 


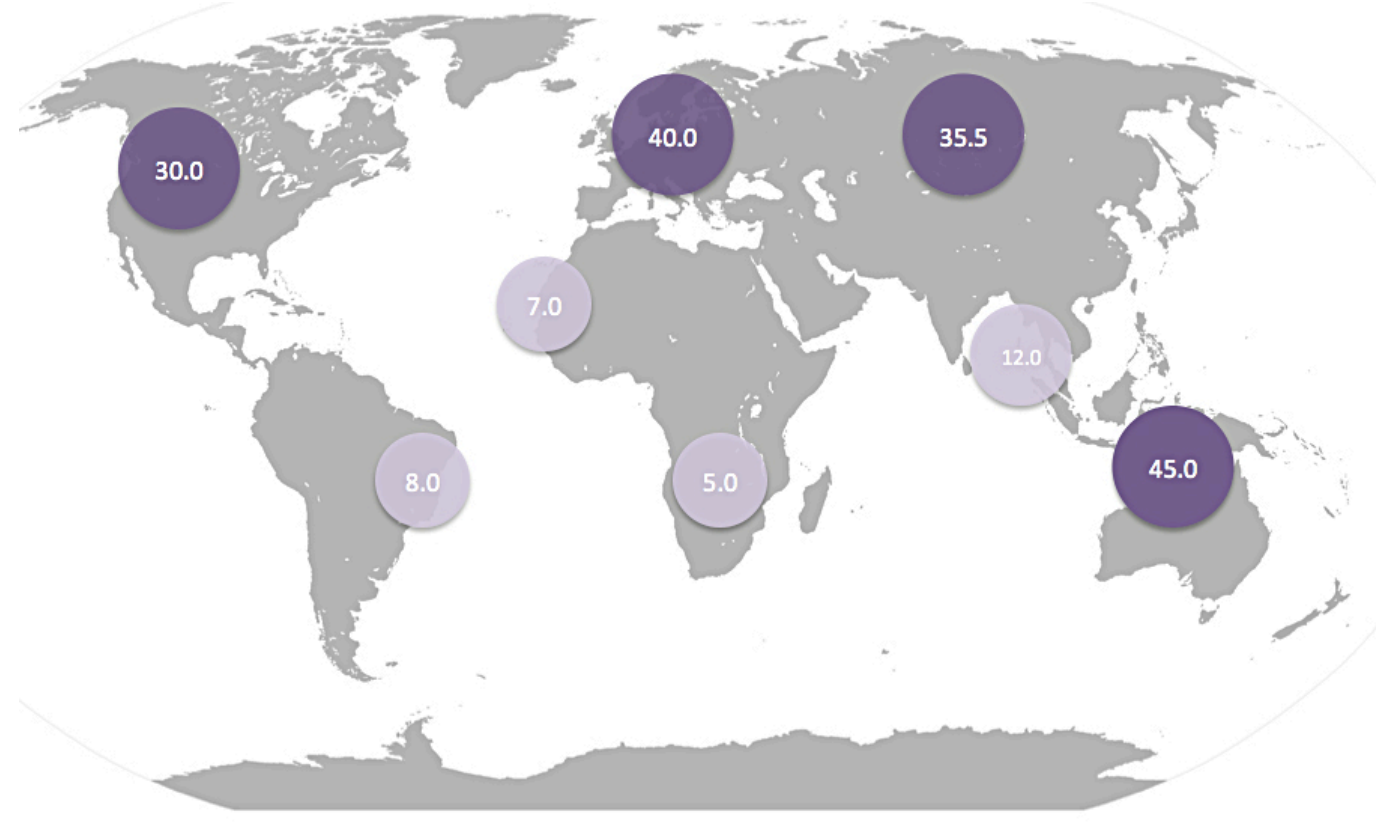

Figure 2 - Estimated colorectal cancer incidence worldwide in 2012 by age-standardized rates per 100,000 individuals.

Adapted from Globocan, 2012.

There are convincing evidences that a western life-style is related to an increase risk of colorectal cancer disease - namely consumption of red meat and processed food, alcohol abuse, chronic smoking, high caloric intake, low vegetable and fruits intake, and physical inactivity are seen as risk factors of colorectal cancer. Another important risk factor in the case of colorectal cancer is the hereditary factor or a history of inflammatory bowel disease (Haggar et al., 2009). On the other hand, physical activity and consumption of dietary fiber, like vegetables and fruits, are linked to cancer prevention (Key et al., 2004).

Awareness and anticipated diagnosis are key factors in an increased survival rate of any oncological patient. Several screening tests have been developed to detect colorectal cancer in early phases. The most common tests are high-sensitivity fecal occult blood tests (FOBT), that checks for tiny amounts of blood in feces that can be from bleeding polyps or tumours; and colonoscopy, in which the rectum and entire colon are examined using a colonoscope and any abnormal growths in the colon and the rectum can be removed (National Cancer Institute, 2014). Jarvinen and colleagues demonstrated that screening colonoscopy at 3-year intervals decreases mortality by about $65 \%$ in Hereditary Non-Polyposis Colorectal Cancer (HNPCC) families (Jarvinen et al., 2000) 


\subsection{Cancer biology}

Douglas Hanahan and Robert A. Weinberg advocate that during development of human tumours, the cells acquire a set of biological capabilities referred as hallmarks. They include sustaining proliferative signaling, evading growth suppressors, escape from apoptosis, enabling replicative immortality, sustained angiogenesis, tissue invasion and metastasis, inflammation, avoiding immune destruction, and deregulating cellular energetics. Genomic instability is now considered another important hallmark and is responsible for generating genetic diversity (Hanahan \& Weinberg, 2011).

\subsubsection{Genomic instability}

Genomic instability corresponds to an increased propensity of cell genome to accumulate alterations during the cell cycle. Ordinarily, it is associated with the failure of parent cells to accurately duplicate the genome and precisely distribute the genomic material among the daughter cells (Kramer et al., 2002; Shen, 2011). During the cell cycle there are four significant mechanisms that ensure genomic stability: (1) highfidelity of DNA replication in the S-phase, (2) accurate distribution of chromosomes among daughter cells during mitosis, (3) error-free repair of sporadic DNA damage through the cell cycle, and (4) cell cycle progression and checkpoint control (Shen, 2011). Changes to the normal function of these mechanisms leads to genetic alterations that provide advantages to these cells allowing them to proliferate, survive and spread. Generally, genetic alterations can be divided into: (1) microsatellite instability (MSI), (2) CpG island methylator phenotype (CIMP) and (3) chromosomal instability (CIN) (Grady, 2004).

Precise repair of sporadic DNA damage is one of the major mechanisms that allows the maintenance of genomic stability throughout the cell cycle. A DNA damage signaling network regulates the activity of repair pathways and their coordination with several biological functions such as cell death. Dysregulation of this efficient network may lead to genomic instability. Furthermore, many of the chemotherapeutic drugs work by causing DNA damage to cancer cells, so it is imperative that the DNA repair mechanisms performs properly without compromising the treatment outcome (Shen, 2011).

A question quite explored by scientists is if genomic instability is the cause or the consequence of cancer, and how it influences the progression of hereditary and sporadic cancers. Loeb suggested that cancer cells must acquire some form of intrinsic 
genomic instability, a "mutator phenotype" (Loeb, 1991). This mutator hypothesis states that genomic instability is present in precancerous lesions, driving to tumour development by increasing the spontaneous mutation rate in caretaker genes.

Germline mutations targeting DNA repair genes, such as BRCA 1 or BRCA 2, are constant in the genome of patient with hereditary cancer. Thus, a single event such as the loss of the remaining wildtype allele would lead to genomic instability and tumour progression (O'Donovan \& Livingston, 2010).

On the contrary, in sporadic cancers the activation of growth signaling pathways due to mutations in oncogenes seems to induce loss of heterozygosity ( $\mathrm{LOH}$ ) and genomic instability involving DNA replication stress. Specific genomic regions, called common fragile sites, are prone to breakage under DNA replication stress. In human precancerous lesions in which oncogenes have been activated, genomic instability preferentially affects common fragile sites (Negrini et al., 2010).

\subsubsection{Cell proliferation}

Under normal conditions cell proliferation is defined by the balance between the number of new cells and the number of cells lost through apoptosis or differentiation. Thus, cell proliferation is a tightly regulated process with the contribution of a wide number of molecules and interconnected pathways, responsible for maintaining the number of cells of an adult tissue constant (Guo \& Hay, 1999)

Cell growth and proliferation can be controlled by the production and release of growth-promoting signals that normally bind to a cell-surface receptor, such as tyrosine kinase receptors (TKRs). TKRs activity is responsible for the recruitment of certain molecules that activate intracellular signaling pathways associated with cell proliferation, differentiation, and others cellular processes (Schlessinger, 2000). Cancer cells can achieve a sustaining proliferative state by disrupting this homeostatic condition trough the dysregulation of TKrs and/or their downstream signal transduction pathways, by increasing growth factors production and also by stimulating production of growth factors by normal cells (Hanahan \& Weinberg., 2011).

Epidermal growth factor receptor (EGFR) and Ras-Raf-MEK-ERK signaling commonly known as the mitogen-activated protein kinase (MAPK) pathway, is a wellknown signal transduction pathway in cell biology. One of the main functions of MAPK pathway is to transduce signals that will be received by the cell nucleus, leading to the activation of specific genes involved in cell growth, division, and differentiation (Molina \& Adjei., 2006). Dysregulation of this pathway leads to an uncontrolled cellular growth and has been reported in several human cancers (Santarpia et al., 2012). 
Another intracellular signaling pathway activated by TKRs and with an important role in tumorogenesis is Phosphatidylinositol 3-kinase (PI3K), protein kinase Akt, and mammalian target of rapamycin (mTOR) also designated as PI3K/AKT/mTOR signaling pathway (Vara et al., 2004).

\subsubsection{Apoptosis}

Apoptosis or programmed cell death is a highly regulated and active mechanism that occurs in response to physiological or pathological stimuli. Apoptosis occurs normally during development and aging, acting like a homeostatic mechanism to maintain cell populations in tissues (Renehan et al., 2001).

Apoptotic cells display a set of unique morphological characteristics that distinguish them from normal cells such as condensation and fragmentation of DNA, blebbing of the membrane, formation of apoptotic bodies and rapid phagocytosis by neighbouring cells without promoting inflammatory response (Kerr et al., 1972; Saraste \& Pulkki, 2000; Elmore, 2007).

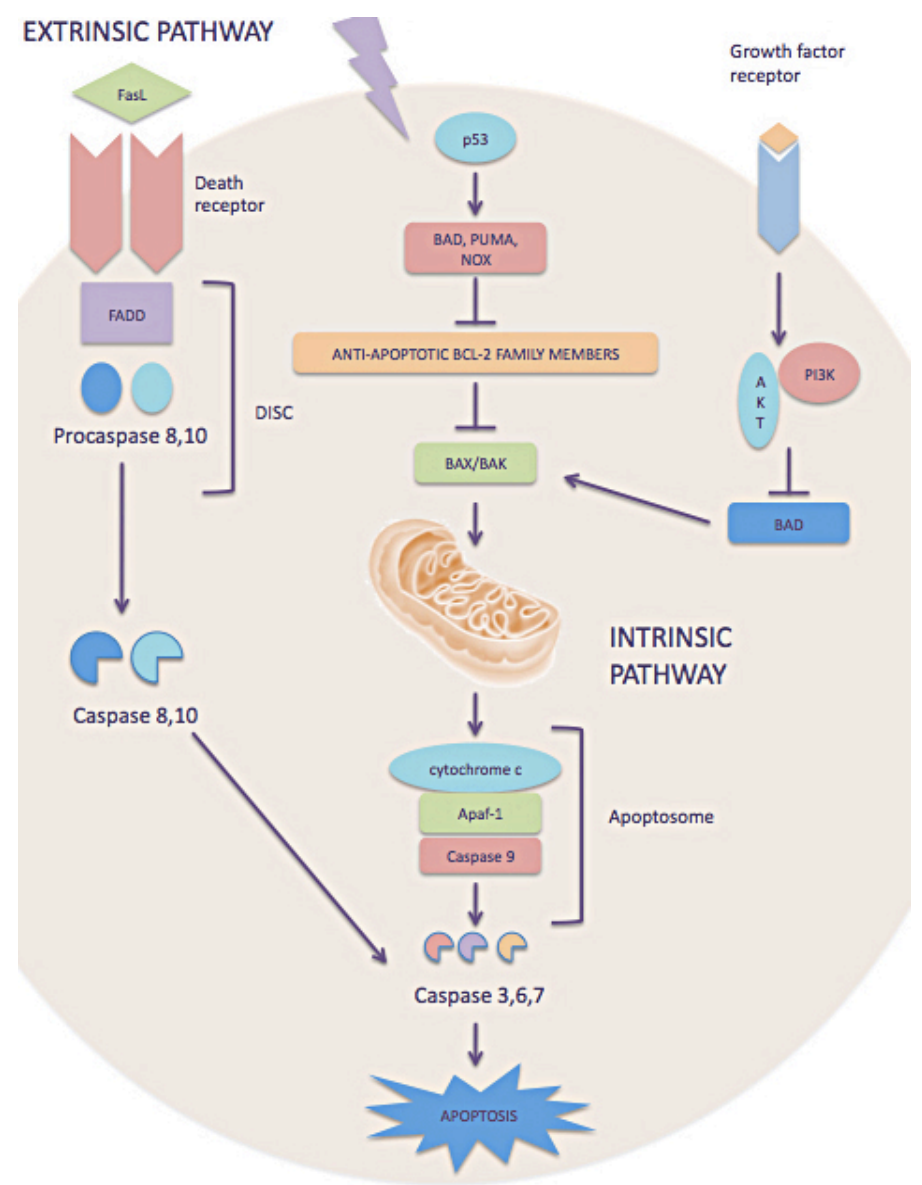

Figure 3 - The two major pathways of apoptosis: extrinsic or intrinsic pathway. Adapted from Ashkenazi, 2008. 
A wide variety of stimuli can induce the activation of the two major pathways of apoptosis, the extrinsic or death receptor pathway and the intrinsic or mitochondrial pathway (Fig. 3) (Elmore, 2007).

The extrinsic pathway is initiated by the activation of death receptors (e.g. FAS and TNFR1), located on the cell surface, by extracellular death ligands (such as FasL or tumour necrosis factor- $\alpha(T N F-\alpha)$ ). Activation of death receptors results in the recruitment of adaptor proteins, such as the Fas-associated death domain protein (FADD), which in turn recruits and aggregates several molecules of procaspases -8 and -10 , forming a complex that is designated as DISC (death-inducing signaling complex). The DISC formation results in auto-activation of pro-caspase 8 , promoting activation of other caspases such as caspase-3, -6 and -7, known as effectors caspases, provoking further caspase activation events that culminate in substrate proteolysis and apoptosis (Fulda \& Debatin, 2007; Taylor et al., 2008; Fardilha \& Cruz e Silva, 2012).

The intrinsic pathway is mediated by several stimuli such as excessive oncogene activation, cell stress, or DNA damage that are recognized by several proteins namely the tumour suppressor TP53, that activates one or more members of the BH3-only protein family (such as BAD, BID, PUMA, NOXA). The proapoptotic BH3only (BIK, HRK, BIM, BAD, BID, PUMA, NOX, BMF), antiapoptotic BCL-2 (BCL-2, BCL-XL BCL-W, MCL1, BCL2A1) and proapoptotic BCL-2 proteins (BAX, BAK and $B O K)$ are known as the B-Cell Lymphoma (BCL-2) family proteins and the ratio between them is a crucial regulator of apoptosis. An increase of $\mathrm{BH}$-only protein family expression overcomes the inhibitory effects of the antiapoptotic BCL-2 proteins and promotes the assembly of BAK-BAX oligomers forming pore in the mitochondrial outer membranes (BAX-BAK channels). These events promote changes in the inner mitochondrial membrane that results in the opening of the mitochondrial permeability transition pore, loss of the mitochondrial transmembrane potential and release of proapoptotic proteins, such as cytochrome c, into the cytosol. The association of cytochrome c, apoptosis protease activating factor 1 (APAF1) and procaspase-9 constitutes a proteic complex designated as apoptosome. Active caspase- 9 , in the apoptosome, propagates a proteolytic cascade of further caspase activation, such as caspase-3, -6 and -7 , that leads to death cell (Taylor et al., 2008; Fardilha \& Cruz e Silva, 2012).

The tumour cells feature a series of maneuvers to limit or escape apoptosis. The most common is the loss of TP53 that acts as damage sensor and consequently inactivates apoptosis (Fridman \& Lowe, 2003). Overexpression of antiapoptotic 
proteins such as $B C L-2, B C L-X L$ BCL-W, MCL1, BCL2A1, or a downregulation of proapoptotic proteins (BAX, BAK and $\mathrm{BOK}$ ) and also $\mathrm{BH}$-only proteins that promote apoptosis (BIK, HRK, BIM, BAD, BID, PUMA, NOX, BMF) may also destabilize the normal mechanism of apoptosis (Adams \& Cory, 2007; Taylor et al., 2008; Lomonosova \& Chinnadurai, 2008).

\subsection{Colorectal cancer}

The colon and the rectum are parts of the large intestine, which is the last part of the digestive system. The main function of the large intestine is to temporarily store the waste of digestion and allow subsequent elimination. The colon is divided into four segments: ascending colon, transverse colon, descending colon and sigmoid colon (Fig. 4).

During digestion, food goes through the stomach and small intestine into the colon. The stool or waste matter goes through the colon by means of peristalsis, first in a liquid state and ultimately in a solid form. As stool moves through the colon, water and nutrients are absorbed. When the descending colon becomes full of stool, it directs them into the rectum for future elimination (National Cancer Institute, 2014).

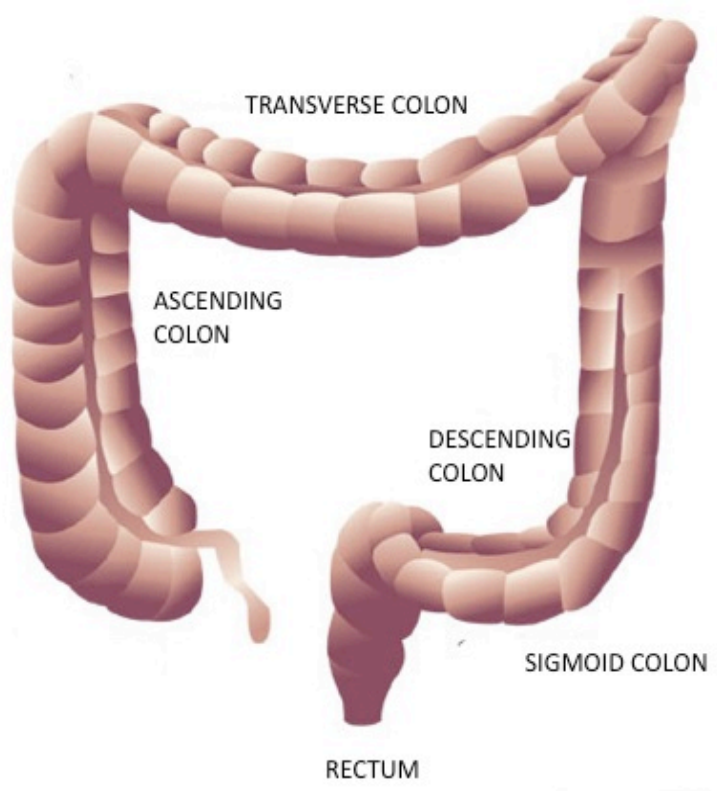

Figure 4 - Colon division in four segments - ascending colon, transverse colon, descending colon and sigmoid colon. 
The progressive reabsorption of water that occurs in the colon leads to a prolonged permanence and exposure of several substances of the stool with the intestinal tract cells. Besides, intestinal tract cells suffer further damage due to the friction created by the removal of water, which induces a strong cell replacement and consequently increases the number of cell divisions. A prolonged exposure of substances allied to an intense cell division rate could be responsible for long-term accumulation of genetic changes (Junqueira \& Carneiro, 2013).

In 1990, Fearon and Volgestein proposed the "adenoma-carcinoma sequence", a multistep genetic model of colorectal carcinogenesis that is characterized by specific mutations in signal transduction pathways (Fig. 5). The first event, and the most common mutation in colorectal cancer, is the inactivation of a tumor suppressor gene known as the adenomatous polyposis coli (APC) (Fearon \& Volgestein, 1990). In the colon, the Wnt pathway is responsible for endoderm formation and for the crypt development, maintenance, and proliferation. It is also involved in the process of epithelial to mesenchymal transition and invasion.

Activation of Wnt pathway occurs when $\beta$-catenin, an oncoprotein, migrates to the nucleus and activates genes that are involved in cellular growth. The APC/ $\beta$ catenin complex is responsible for controlling the levels of $\beta$-catenin protein through its degradation (MacDonald et al., 2009). Mutation in the APC gene results in a constant activation of Wnt pathway leading to events of uncontrolled proliferation that result in aberrant crypt foci (Goss \& Groden, 2000).

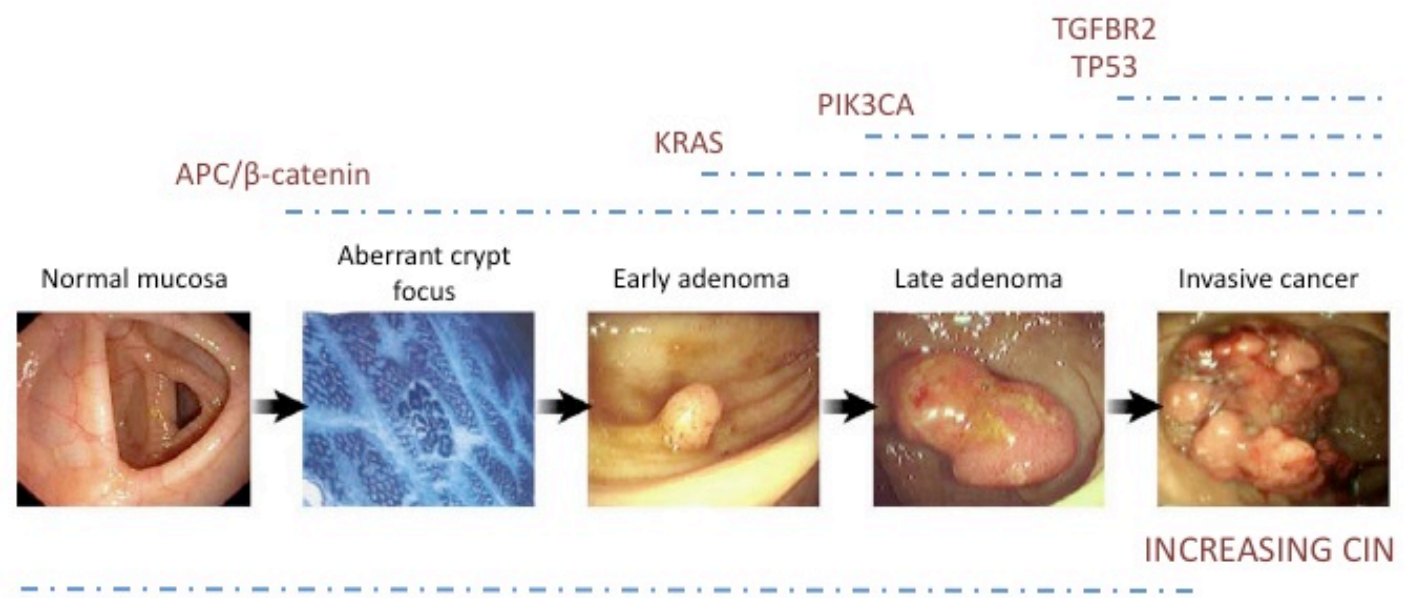

Figure 5 - Multistep genetic model of colorectal carcinogenesis. Adapted from Pino and Chung, 2010.

As previously mentioned, mitogenic-activate protein kinases, best known as MAPKs, are serine-threonine kinases that mediate intracellular signaling associated 
with cell proliferation, differentiation, death and other cellular activities. The MAPK pathway is activated by several extracellular signals, such as oxidative stress, and intracellular stimuli including cytokines, hormones, among others (Kim \& Choi, 2010).

The following event on this multistep genetic model is oncogenic mutation of RAS, an oncogenic small GTPase, which activates the MAPK signaling pathway. Mutations of KRAS, one of the three isoforms of RAS, leads to a permanently active state that allows the cell to evade apoptosis and acquire a growth advantage (Calcagno et al., 2008). This type of mutation is detected in over a third of human colorectal cancers (Bos et al., 1987).

$\mathrm{PISK} / \mathrm{AKT} / \mathrm{mTOR}$ signaling pathway regulates relevant cellular functions, such as proliferation, growth and survival (LoPicollo et al., 2008). Over activation of PI3K and AKT is considered a key factor for tumour progression (Karakas et al., 2006). One third of colorectal cancers have this pathway constitutively activated due to somatic mutations on PI3K (Markowitz \& Bertagnolli, 2009).

During the carcinogenesis process, progression to larger adenomas and carcinomas requires mutations in TP53 gene (located on chromosome 17p) (Schwitalla et al., 2013). The encoded protein p53 is a well-known tumor suppressor protein that has several functions such as induction of cell cycle arrest, apoptosis, senescence, and DNA repair in response to cellular stress. In most tumors, the two p53 alleles are inactivated, usually by a combination of a missense mutation and a $17 p$ chromosomal deletion (Baker et al., 1989).

Another genetic alteration that occurs in colorectal cancer is TGFBR2 (transforming growth factor $\beta$ receptor II) mutations. Transforming growth factor beta (TGF- $\beta$ ) are multifunctional peptides that regulate proliferation, differentiation, adhesion and migration by transducing their signal through combinations of transmembrane receptors and their downstream effectors, SMAD proteins. In this particularly case, TGF- $\beta$ works as an inhibitor of intestinal epithelial cell proliferation and inducer of apoptosis. In cancer, the TGF- $\beta$ signaling pathway is changed by mutations in the receptors and in the intracellular mediators (e.g. Smad4 and Smad2) (Xu \& Attisano, 2000).

The acquisition of genomic instability, along with this series of events, is recognized as a crucial feature on tumour development. An imbalance in chromosome number, subchromosomal genomic amplifications, and a high frequency of loss of heterozygosity $(\mathrm{LOH})$ come as a result of chromossomal instability (CIN). The CIN phenotype is a hallmark of solid cancers and is observed in $65 \%-70 \%$ of sporadic colorectal cancers (Pino \& Chung, 2010). 


\subsection{Therapeutic approaches}

There are several therapeutic approaches that can be used in the treatment of a neoplastic disease such as surgery, radiation, chemotherapy, hormone therapy, immunotherapy and targeted therapy. Concerning colorectal cancer, surgery allied to chemotherapeutic drug administration is the most widely used treatment.

Hormones and anti-hormones (substances capable of blocking the action of a certain hormone) are often applied in the treatment of breast and prostate cancer, since hormonal environment is crucial for tumor expansion. Hormones and antihormones are seen mainly as effective in mitigating symptoms (Cancer Research UK). Lin and colleagues proposed that Gucy2c, an intestinal cell receptor, and its ligands, guanylin and uroguanylin, could act as possible candidates for anti-colorectal cancer therapy. Guanylin and uroguanylin expression is associated with the transition of a proliferative state to a differentiate state along the crypt-villus axis and, in colorectal cancer are among the most ordinarily lost gene products. Furthermore, Gucy2c receptors acts as a tumour suppressor through AKT inhibition, promoting epithelial homeostasis (Lin et al., 2010). Another study evaluated the up-take of menopausal hormones such as estrogen and progestin, and the risk of colorectal cancer in women. The results showed that a sequential regimen use of estrogen plus progestin was associated with a higher reduced risk of colorectal cancer (Johnson et al., 2009).

Immunotherapy resorts to biological agents - immunomodulators that mimic some of the natural signals involved in cell growth control or acts indirectly in healthy cells. Immunomodulators are administered to patients to imitate or influence the natural immune response. Anticancer immunotherapy for colorectal cancer has been highlighted in the scientific community. Several immunotherapeutic approaches such as cancer vaccines and adaptative cell therapy are currently under investigation in order to minimize toxicity in colorectal patients (Xiang et al., 2013).

Targeted cancer therapies resort to drugs that are able to block the growth and spread of cancer by interfering with specific molecules involved in the growth, progression and spread of cancer. Unlike chemotherapeutic drugs, targeted drugs are designed to act specifically in cancer cells and not in healthy cells although some side effects can emerge (Gerber, 2008). For example, angiogenesis is the process of making new blood vessels. During tumor progression angiogenesis is activated and remains on, providing the tumor with enough blood supply to continue growing. Drugs such as angiogenesis inhibitors stop tumors by blocking the formation of new blood vessels, through inhibition of vascular endothelial growth factor (VEGF) proteins or the 
VEGF receptors. Bevacizumab (Avastin) and ramucirumab (Cyramza) are examples of angiogenesis inhibitors (Rosen, 2005).

At the level of chemotherapy, the antineoplastic agents, also called cytotoxic agents, are used in the treatment of malignant neoplasms, normally in situations in which surgery or radiotherapy proved powerless or, as a complementary treatment. In most cases, chemotherapy results in a combination of drugs in order to achieve a cytotoxic effect in a heterogeneous population of neoplastic cells, preventing the development of resistant clones. In an attempt that the combination of drugs is ideal, it is necessary to take into account the several aspects: 1) each of the drugs must show activity against the tumor in question; 2) should display different mechanisms of action; 3) cross-resistance between the intervenient must be minimized; 4) toxic effects should differ for each drug used (Cancer Network, 2005).

For example, the ABVD is a known combination of cytotoxic compounds consisting of Doxorubicin (Adriamicin), Bleomycin, Vinblastine and Dacarbazine. Among these compounds we can mention the Bleomycin, a generic name given to a group of antibiotics isolated from Streptomyces verticillus, with anti-tumor activity that selectively inhibit the synthesis of DNA (Galm et al., 2005). Also, Vinblastin, an important alkaloid that behaves as a strong proliferation inhibitor through the disruption of microtubules function (Panda et al., 1996). However a crucial aspect to be taken into consideration is the adverse effects of cytotoxic compounds in humans. It is important to create a balance between the therapeutic effect and the level of toxicity (Ma \& Lu, 2011).

\subsubsection{5-Fluorouracil (5-Fu)}

The fluoropyrimidine, 5-fluorouracil (5-Fu), is one of the most commonly used chemotherapeutic drugs and it is used to treat many types of cancer such as breast cancer, colorectal cancer, head and neck cancers. Usually, it is combined with other cancer drugs or with radiotherapy. 5-fluorouracil is an analogue of uracil, with a fluorine atom at the C-5 position in place of hydrogen, and it is classified as an antimetabolite (Fig. 6) (Bracht et al., 2010). Antimetabolite drugs work by inhibiting fundamental biosynthetic processes, or by integration into DNA and RNA, compromising their normal function (Duci, 2015). 
<smiles>O=c1[nH]cc(F)c(=O)[nH]1</smiles>

5-Fluorouracil<smiles>O=c1cccc[nH]1</smiles>

Uracil

Figure 6 - Chemical structure of fluorouracil and uracil.

5-Fu is converted intracellularly into three active metabolites: fluorodeoxyuridine monophosphate (FdUMP), fluorodeoxyuridine triphosphate (FdUTP) and fluorouridine triphosphate (FUTP). These are responsible for induction of RNA and DNA damage, through incorporation of its metabolites into nucleic acids, and inhibition of the nucleotide synthetic enzyme thymidylate synthase (TS) and consequently inhibition of DNA synthesis (Longley et al., 2003).

Like other chemotherapeutic drugs, some unwanted effects may emerge due to the treatment with fluorouracil. Side effects in the gastrointestinal tract are considered the most severe. Stomatitis and esophagopharyngitis, diarrhea, anorexia, nausea and emesis are commonly seen during treatment. Resistance of $5-\mathrm{Fu}$ is another undesirable effect and may emerge due to several mechanisms, namely over expression of TS and alterations in apoptotic pathway (Zang et al., 2008). Because of these important limitations, combination with other drugs has been emerged as a new strategy.

\subsection{Marine natural compounds}

The research of bioactive compounds in different marine organisms (e.g. marine algae, sponges, corals) as potential antitumor agents has been highly exploited in the last decades. The chemical and biological diversity of the marine environment is incalculable, making this a reservoir of natural bioactive compounds. Many of these products exhibit structural and chemical characteristics that are not found in natural terrestrial compounds. The intense concentration of species in certain habitats makes these highly competitive and complex organisms. For example, sessile organisms such as corals or sponges are in constant struggle for having an appropriate fixation space, and by adopting certain mechanisms that can be chemical, structural and behavioral 
they can guarantee their survival (Giangrande et al., 2014). In view of this extremely competitive situation a large proportion of species have developed chemical adaptations that enable them to defend themselves against predation and also represent an advantage in situations of competition. Generally, these adjustments are chemical designated by secondary metabolites and cover a large diversity of compounds such as terpenoids, sugars, alkaloids, steroids, among others (Simmons et al., 2005).

In 2007, trabectedin (ET-743) a marine alkaloid isolated from the Caribbean tunicate (Ecteinascidia turbinata) obtained marketing authorization from the European Commission for the treatment of advanced soft tissue sarcoma, and in 2009 it received marketing authorization for the treatment of platinum-sensitive ovarian cancer (D'Incalci and Galmarini, 2010). Another example of a marine compound approved as a therapeutic drug in leukemia is Cytostar- $U$, a synthetic pyrimidine nucleoside based on spongothymidine isolated from a sponge (Tethya crypta) (Löwenberg et al., 2011).

\subsection{Marine algae}

Algae are unicellular or pluricellular organisms that contain chlorophyll. In a simple way, algae can be classified into two major groups, microalgae and macroalgae. Microalgae are found in benthic and littoral habitats and also throughout the ocean waters as phytoplankton. Blue green algae, dinoflagellates, diatoms are included in this group. The group of macroalgae or seaweeds includes green (Chlorophyta), brown (Phaeophyta) and red (Rodhophyta) algae and has been founded in the littoral zone (EI Gamal, 2010).

Several species of macroalgae have been used as human and animal food since very early times, especially in China and Japan, such as Nori (Porphyra spp.), wakame (Undaria pinnatifida) and kombu (Laminaria japonica). In this region, they also have been used to treat many diseases that show iodine deficiency (e.g. hyperthyroidism, goiter and Basedow's disease).

Regarding chemical composition, 70 to $90 \%$ of the weight of fresh macroalgae is water, containing also considerable amounts of polysaccharides such as fucoidans present in brown macroalgae, that are responsible for about $45-75 \%$ of its dry weight. This is followed by proteins that make up $7-35 \%$ of macroalgae dry weight and fats, less than 5\% (Lopes, 2014). Another important compound found in macroalgae is carotenoids, which are essential components in photosynthesis and exhibit a powerful antioxidant activity (Takaichi, 2011). Polyphenols, also designated by phlorotannins, known as effective antioxidants are found as well in macroalgae, especially in brown 
algae (Iwai, 2008). lodine, calcium, phosphorous, magnesium, iron, sodium, potassium and chlorine are the main mineral elements presents and they are accountable for several macroalgae health benefits. Furthermore, macroalgae are also rich in vitamin A, vitamin C and vitamins from B complex (Burtin, 2003).

Studies on the bioactivities of marine algae have showed several healthpromoting effects such as antioxidant, antimicrobial, anti-inflammatory and anticancer effects in several biological models (Raja et al., 2013).

\subsubsection{Fucoxanthin}

Fucoxanthin, a marine carotenoid, can be found in marine brown macroalgae (Phaeophyceae) and microalgae diatoms (Bacillariophyta). The chemical structure of fucoxanthin includes an allelic bond and some oxygenic functional groups, such as epoxy, hydroxyl, carbonyl and carboxyl groups (Fig. 7) (Peng et al., 2011).
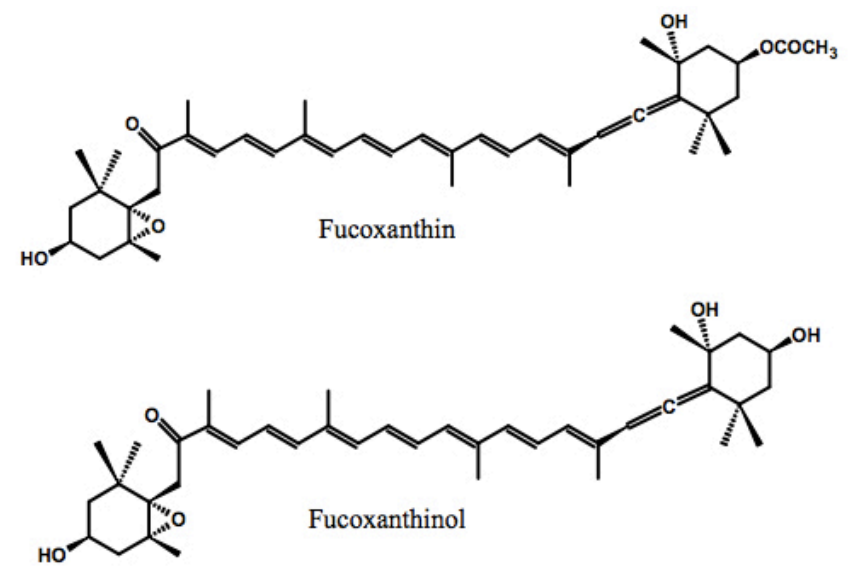

Figure 7 - Chemical structure of fucoxanthin and its deacetylated metabolite, fucoxanthinol.

Sugawara and colleagues, reported that dietary fucoxanthin is hydrolyzed to fucoxanthinol, the major fucoxanthin deacetylated metabolite, in the intestinal tract by lipase and cholesterol esterase. Then, fucoxanthinol is taken up by the intestinal cells and is secreted into the blood circulation system in mammals (Sugawara et al., 2002). Several studies have shown that fucoxanthin and/or fucoxanthinol displays a huge number of beneficial effects in human health. Antioxidant, anti-inflammatory, anticancer, anti-obesity, antidiabetic effects are examples of known fucoxanthin bioactivities.

Apoptotic events in cancer cells are a promising method to control and treat cancer. Hosokawa and colleagues have demonstrated that fucoxanthin decreased cell viability in Caco-2, HT-29 and DLD-1 colorectal cancer cell lines. Furthermore, it 
induces DNA fragmentation, a typical characteristic of apoptotic cells, and suppresses the levels of $\mathrm{Bcl}-2$ protein. The Caco-2 cell line when treated with a combination of fucoxanthin and troglitozone at $3.8 \mu \mathrm{M}$ and $10 \mu \mathrm{M}$ respectively, showed a decreased in cell viability. However, the compounds alone and the same concentrations were not able to affect the viability of Caco-2 cell line (Hosokawa et al., 2004).

In a recent study, the anticancer effects of fucoxanthin and fucoxanthinol in six colorectal cancer cell lines and in twenty cases of colorectal cancer specimens, resected surgically from patients, was investigated using the CD-DST technique. The CD-DST mimics the environment of the human body through the use of threedimension collagen gel, and has been used in clinical practice to select effective chemotherapeutic drugs. The results were obtained in the form of $T / C(\%)$, where $T$ is the absorbance of cells which stained by neutral red treated with carotenoids and $\mathrm{C}$ is the absorbance of non-stained cells. Fucoxanthin and fucoxanthinol showed anticancer effects in a dose-dependent manner in colorectal cancer cell lines and in the colorectal cancer specimens. Another relevant aspect was that the median of T/C (\%) of the 20 samples subjected to fucoxanthinol at $10 \mu \mathrm{M}$ was similar to a treatment with 5-FU and paclitaxel in a standard dose used in clinical practice (Takahashi et al., 2015).

One of the most exciting aspects of fucoxanthin is the fact that it is apparently a safe compound in terms of mutagenicity. Beppu and colleagues, observed the incidence of micronucleus and mutagenicity of fucoxanthin in bone marrow cells of mice that were orally administered for $24 \mathrm{~h}$. The results for micronucleus and mutagenicity were found to be negative (Beppu et al., 2009).

\subsubsection{Phloroglucinol}

Phlorotannins, a subgroup of tannins found only in brown algae, are oligomeric compounds of phloroglucinol units (Fig. 8). Six kinds of phlorotannins can be isolated of Ecklonia species, such as phloroglucinol (1,3,4-trihydroxybenzene), triphlorethol-A (an open-chain trimer of phloroglucinol), eckol (a closed-chain trimer of phloroglucinol), dieckol (a hexamer), phlorofucofuroeckol (a pentamer) and 6,6'-bieckol (a hexamer) (Kang et al., 2006).

Ecklonia cava is a brown algae, from the family of Laminariceae that grows in subtidal zone in water depth from 5 to 20 meters. It can be found in many warm temperate regions such as China, Japan and Korea (seaweed industry). This brown algae exhibits many biological activities that can be useful in the medical field. For example, a study conducted by Wijesinghe and colleagues, showed that extracts of Ecklonia cava are able to inhibit angiotensin l-converting enzyme (ACE) activity. This 
inhibition is essential in the treatment of hypertension (Wijesinghe et al., 2011). Chaudhuri and colleagues evaluated the effect of phloroglucinol derivatives against gastric ulceration in mice, and concluded that phloroglucinol derivatives were able to attenuate gastric ulceration due to their antioxidant activity (Chaudhuri et al., 2011).

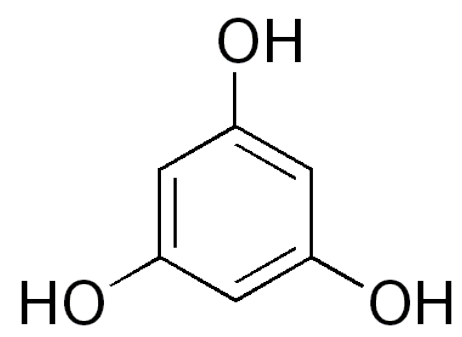

Figure 8 - Chemical structure of phloroglucinol.

Phloroglucinol is one of the phloratannins that have been assessed in some anticancer studies. A recent study evaluated the anticancer effects of phloroglucinol on apoptosis and insulin-like growth factor-1 receptor (IGF-1R) signaling in HT-29 human colon cancer cells. The results showed that cells treated with phloroglucinol exhibited fragmented nuclei and condensed chromatin, characteristic of an apoptotic cells. Phloroglucinol also reduced the expression of IGF-1R inhibiting cancer cell proliferation (Kang et al., 2014). The same investigators, but in a different study, observed that phloroglucinol inhibits cell growth and induces apoptosis in HT-29 colon cancer cells via both extrinsic and intrinsic cell death signaling pathways. It was observed that protein expression levels of Fas, FADD and caspase-8 were higher in cells treated with phloroglucinol. In the intrinsic signaling pathway, phloroglucinol induces a decrease in $\mathrm{Bcl}-2$ and $\mathrm{Bcl}-\mathrm{xL}$ expression (anti-apoptotic proteins) and an increase in Bax and Bad expression (pro-apoptotic proteins) (Kang et al., 2014).

\subsection{Methodologies available to screen anticancer activity}

In the field of drug development, evaluation of the anticancer activity, side effects in normal cells and elucidation of the mechanisms are the first step to be taken to evaluate the potential activity of the compound, before starting the long period of clinical trials and marketing permission.

When a compound is found and presented as a candidate therapeutic agent it is crucial that it doesn't display mutagenic effects in healthy cells. A mutagen can interact 
directly with the DNA molecule or indirectly through formation of reactive compounds that can act with other components of the cell, or both situations. If the damage caused by the agent is not liable to repair, the cellular response can occur in two possible ways: cell death or cell survival with mutations, the latter resulting in changes of the genetic code transmitted to the daughters cells (Słoczyńska et al., 2014).

Nowadays, several methodologies are available to perform screening tests with several advantages and limitations associated. The use of cancer cell lines as a model for these screening tests has been extensively used and also normal cell lines appear as relevant models to assess specificity. López-Lázaro proposed a basic protocol that includes preclinical in vitro and in vivo testing to assess if a drug is a possible candidate for clinical trials. The preclinical in vitro tests evaluate the anticancer activity of a candidate drug in cancer cells from a particular tissue and in nonmalignant cells from a variety of tissues, and compares it with the anticancer activity of a standard drug under the same conditions. This strategy allows to find a drug capable of killing cancer cells without affecting nonmalignant cells which is the main objective in cancer research (López-Lázaro, 2015).

\subsubsection{Cell viability/proliferation assays}

The first evaluation of a drug action is usually done through the determination of its effect on cell growth rates. Cell viability or proliferation can be determined, depending on what factor is being measured, in four different ways: metabolic activity, DNA synthesis, antigens related with cell proliferation and ATP concentration (Biocompare, 2012).

The colorimetric MTT assay is a simple and fast method that assesses cell viability or proliferation. It is considered one of the most popular and versatile tests to determine cytotoxicity associated with metabolic activity. Viable cells with an active metabolism are able to convert MTT (3-(4,5-dimethylthiazol-2-yl)-2,5diphenyltetrazolium bromide) into formazan crystals. The formazan crystals accumulate as an insoluble precipitate inside the cells. They are also present near the cell surface and in the culture medium. The crystals can be extracted and dissolved with DMSO (an organic solvent), allowing its quantification by reading absorbance at $570 \mathrm{~nm}$ in a spectrophotometer. Higher absorbance values correspond to a higher number of living cells in the sample (Mosmann, 1983).

Other methods to assess proliferation through DNA synthesis measurement are frequently used. An example is BrdU assay in which a modified nucleotide, such as bromodeoxyuridine (BrdU) can be incorporated into cellular DNA during cell 
proliferation. BrdU being a pyrimidine analog will be incorporated by proliferating cells, in place of thymidine into the newly synthesized DNA. BrdU presence can be tracked using antibody probes responsible for developing color that will be assessed by absorbance values or fluorescence (Crane \& Bhattacharya, 2013).

\subsection{Evaluation of the possible action mechanisms}

\subsubsection{Genotoxicity evaluation by comet assay}

The comet assay is a simple, versatile and quick assay to detect DNA damage in individualized cells. It can be applied to proliferative cells but also to non-proliferating cell population. This aspect is clearly important since these types of cells and tissues are the first to come into contact with potential toxic substances (Kassie et al., 2000)

In 1984, Ostling and Johanson presented the first protocol of comet assay. Generally, the protocol consisted of soaking isolated cells in agarose followed by lysis in a highly saline solution and then performing an electrophoresis in neutral conditions to allow the migration of DNA loops. This approach allows detecting, specifically, double strand breaks in the DNA. Singh and colleagues (1988) carried out for the first time the comet assay on alkaline conditions $(\mathrm{pH}>13)$. This modification made the test able to detect not only double breaks in the DNA but also simple strand breaks, alkalilabile sites, cross-links and incomplete excision-repair sites. More recently, the introduction of repair enzymes after lysis allowed identifying different damages that initially are not strand breaks such as oxidized bases. The most commonly used enzymes are endonuclease III, FPG and AlkA that detect oxidized pyrimidines, purines and modified alkyl purine, respectively (Collins, 2008).

The assessment of damage can be done by two ways: through visual observation of cells by assigning a score of 0 to 4 which corresponds to the intensity of fluorescence in the tail or using software that automatically measures several parameters namely tail intensity. An increase of the fluorescence intensity in the tail of the comet means that the number of breaks is increased and so more damage exist (Gyori et al., 2014). 


\subsubsection{Apoptosis}

Nuclear condensation assays provide a convenient approach for analysis of apoptosis by microscopy. During apoptosis several morphological characteristics appear, such as condensation and fragmentation of DNA, blebbing of the membrane and formation of apoptotic bodies (Elmore, 2007). Using a nuclear and chromosome counterstain, like DAPI, cells with condensed nuclei can be counted.

Another assay that is used to determine apoptotic cells is annexin- $\mathrm{V}$. In an initial phase of apoptosis, cells loose plasma membrane asymmetry and the membrane phospholipid phosphatidylserine (PS) normally found in the inner leaflet of the plasma membrane is translocated to the outer leaflet. Annexin- $\mathrm{V}$ is a $\mathrm{Ca}^{2+}$-dependent phospholipid-binding protein that shows high affinity for PS. Thus, exposed PS in the external cellular environment will be subject to annexin-V binding (Walton et al, 1997). Using annexin- $V$ conjugated with fluorochromes allows detection of apoptotic cells using flow cytometry or microscopy.

\subsubsection{Western blot}

In response to external stimulus (potential anticancer drug) several proteins involved in survival and death pathways can be inactivated or activated. An example is the activation of several cytosolic proteases known as caspases, e.g. caspases $-8,-9$ and -3 in response to an apoptotic event (Taylor et al., 2008).

Western blot, or immunoblotting, was introduced by Towbin and colleagues in 1979 , and is widely used to separate and identify proteins. In a simplistic manner, the identification of a specific protein is accomplished in three steps: (1) separation by size (molecular weight), (2) transfer to a solid support, and (3) marking target protein, using a suitable primary and secondary antibody (Mahmood \& Yang, 2012).

The aim of this study was to assess the in vitro anticancer bioactivity of two algae compounds, fucoxanthin and phloroglucinol, alone and in co-incubation with 5-Fu on two colorectal cancer cell lines (HCT-116 and HT-29), ressorting to preclinical in vitro tests. Also, to assess the specificity of the anticancer effects, a normal colon cell line (CCD-Co18) was tested. 


\section{REFERENCES}

Adams, J. M., \& Cory, S. (2007). The Bcl-2 apoptotic switch in cancer development and therapy. Oncogene, 26(9), 1324-1337.

Anand, P., Kunnumakara, A. B., Sundaram, C., Harikumar, K. B., Tharakan, S. T., Lai, O. S., Sung, B., Aggarwal, B. B. (2008). Cancer is a preventable disease that requires major lifestyle changes. Pharmaceutical Research, 25(9), 2097-2116.

Baker, S. J., Fearon, E. R., Nigro, J. M., Hamilton, S. R., Preisinger, a C., Jessup, J. M., Vogelstein, B. (1989). Chromosome 17 deletions and p53 gene mutations in colorectal carcinomas. Science (New York, N.Y.), 244(4901), 217-221.

Beppu, F., Niwano, Y., Sato, E., Kohno, M., Tsukui, T., Hosokawa, M., \& Miyashita, K. (2009). In vitro and in vivo evaluation of mutagenicity of fucoxanthin (FX) and its metabolite fucoxanthinol (FXOH). The Journal of Toxicological Sciences, 34(6), 693698.

Biocompare. Smith, C. Cell Proliferation Assays: Methods for Measuring Dividing Cells. Retrieved August 13, 2015, from http://www.biocompare.com/Editorial-Articles/117892Cell-Proliferation-Assays/

Bos, J. L., Fearon, E. R., Hamilton, S. R., Vries, M. V., van Boom, J. H., van der Eb, A. J., \& Vogelstein, B. (1987). Prevalence of ras gene mutations in human colorectal cancers. Nature, 327(6120), 293-297.

Bracht, K., Nicholls, a M., Liu, Y., \& Bodmer, W. F. (2010). 5-Fluorouracil response in a large panel of colorectal cancer cell lines is associated with mismatch repair deficiency. British Journal of Cancer, 103(3), 340-346.

Burtin, P. (2003). Nutritional Value of Seaweeds. Electronic Journal of Environmental, Agricultural and Food Chemistry, 2(4), 1579 - 4377.

Calcagano, S. R., Li, S., Colon, M., Kreinest, P. A., Thompson, E. A., Fields, A. P., \& Murray, N. R. (2008). Oncogenic K-ras promotes early carcinogenesis in the mouse proximal colon. International Journal of Cancer, 76(6), 1358-1375.

Cancer Network. Takimoto, C. H., \& Calvo, E. Principles of oncologic pharmotherapy. Retrieved June 6, 2015, from http://www.cancernetwork.com/articles/principlesoncologic-pharmacotherapy

Chaudhuri, S. R., Modak, A., Bhaumik, A., \& Swarnakar, S. (2011). PHLOROGLUCINOL DERIVATIVES AS POTENTIAL ANTI- METALLOPROTEINASE9, 2(4), 237-252.

Collins, A. R., Oscoz, A. A., Brunborg, G., Gaivão, I., Giovannelli, L., Kruszewski, M., Smith, C. C., Stetina, R. (2008). The comet assay: topical issues. Mutagenesis, 23(3), 143-51.

Cooper, GM. (2000). The Cell: A Molecular Approach. 2nd edition. Sunderland (MA): Sinauer Associates. 
Crane, A., \& Bhattacharya, S. (2013). The Use of Bromodeoxyuridine Incorporation Assays to Assess Corneal Stem Cell Proliferation. In B. Wright \& C. J. Connon (Eds.), Corneal Regenerative Medicine SE - 4 (Vol. 1014, pp. 65-70).

Duci, S. B. (2015). Justification of the topical use of pharmacological agents on reduce of tendon adhesion after surgical repair. SM Journal of Orthopedics, 1(2), 2-4.

D'Incalci, M., \& Galmarini, C. M. (2010). A review of trabectedin (ET-743): a unique mechanism of action. Molecular Cancer Therapeutics, 9(8), 2157-2163.

El Gamal, A. a. (2010). Biological importance of marine algae. Saudi Pharmaceutical Journal, 18(1), 1-25.

Elmore, S. (2007). Apoptosis: A review of Programmed Cell Death. Toxicol Pathol, 29(6), 997-1003.

Fardilha, M., \& Cruz e Silva, O. A. B. (2012). O Essencial em Sinalização Celular. Edições Afrontamento, Lda.

Fearon, E. R., \& Vogelstein, B. (1990). A genetic model for colorectal tumorigenesis. Cell, 61(5), 759-67

Ferlay, J., Soerjomataram, I., Dikshit, R., Eser, S., Mathers, C., Rebelo, M., Parkin, D. M., Forman, D., Bray, F. (2015). Cancer incidence and mortality worldwide: Sources, methods and major patterns in GLOBOCAN 2012, 386.

Fulda, S., \& Debatin, K.-M. (2006). Extrinsic versus intrinsic apoptosis pathways in anticancer chemotherapy. Oncogene, 25(34), 4798-4811.

Fridman, J. S., \& Lowe, S. W. (2003). Control of apoptosis by p53. Oncogene, 22(56), 9030-9040.

Galm, U., Hager, M. H., Van Lanen, S. G., Ju, J., Thorson, J. S., \& Shen, B. (2005). Antitumor Antibiotics: Bleomycin, Enediynes, and Mitomycin. Chemical Reviews, 105(2), 739-758.

Gerber, D. E., \& Gerber, D. E. (2008). Targeted therapies: a new generation of cancer treatments. American Family Physician, 77(3), 311-9.

Giangrande, A., Licciano, M., Schirosi, R., Musco, L., \& Stabili, L. (2014). Chemical and structural defensive external strategies in six sabellid worms (Annelida). Marine Ecology, 35(1), 36-45.

Globocan 2012 : Estimated Cancer Incidence, Mortalitty and Prevalence Worldwide in 2012 Retrieved June 21, 2015, from http://globocan.iarc.fr/Pages/ fact_sheets_cancer. aspx

Goss, K. H. \& Groden, J. (2000) Biology of the adenomatous polyposis coli tumor suppressor. Journal of Clinical Oncology, 18, 1967-79.

Grady, W.M. (2004). Genomic instability and colon cancer. Cancer Metastasis Rev, 23(1-2), 11-27.

Guo, M., \& Bruce, A. H. (1999). Cell proliferation and apoptosis. Cell Biology, 11, 745752. 
Gyori, B. M., Venkatachalam, G., Thiagarajan, P. S., Hsu, D., \& Clement, M.-V. (2014). OpenComet: An automated tool for comet assay image analysis. Redox Biology, 2, 457-465.

Hajdu, S. I. (2011). A note from history: landmarks in history of cancer, part 1. Cancer, 117(5), 1097-1102.

Haggar, F. A., Boushey, R. P., \& Ph, D. (2009). Colorectal Cancer Epidemiology: Incidence , Mortality , Survival, and Risk Factors. Clinics in Colon and Rectal Surgery, 6(212), 191-197.

Hanahan, D., \& Weinberg, R. A. (2000). Hallmarks of cancer. Cell, 100(1), 646-74.

Hanahan, D., \& Weinberg, R. A. (2011). Hallmarks of cancer: the next generation. Cell, 144(5), 646-74.

Hosokawa, M., Kudo, M., Maeda, H., Kohno, H., Tanaka, T., \& Miyashita, K. (2004). Fucoxanthin induces apoptosis and enhances the antiproliferative effect of the PPARY ligand, troglitazone, on colon cancer cells. Biochimica et Biophysica Acta (BBA) General Subjects, 1675(1-3), 113-119.

Iwai, K. (2008). Antidiabetic and Antioxidant Effects of Polyphenols in Brown Alga Ecklonia stolonifera in Genetically Diabetic KK-Ay Mice. Plant Foods for Human Nutrition, 63(4), 163-169.

Järvinen, H. J., Aarnio, M., Mustonen, H., Aktan-Collan, K., Aaltonen, L. A., Peltomäki, P., De La Chapelle, A., Mecklin, J. P. (2000). Controlled 15-year trial on screening for colorectal cancer in families with hereditary nonpolyposis colorectal cancer. Gastroenterology, 118(5), 829-834.

Jemal, A., Bray, F., Center, M. M., Ferlay, J., Ward, E., \& Forman, D. (2011) Global cancer statistics. CA Cancer J Clin, 61(2), 69-90.

Johnson, J. R., Lacey, J. V, Lazovich, D., Geller, M. a, Schairer, C., Schatzkin, A., \& Flood, A. (2009). Menopausal hormone therapy and risk of colorectal cancer. Cancer Epidemiology, Biomarkers \& Prevention: A Publication of the American Association for Cancer Research, Cosponsored by the American Society of Preventive Oncology, 18(1), 196-203.

Junqueira, L. C., \& Carneiro, J. (2013). Histologia Básica - Texto e Atlas (12th ed.). Guanabara Koogan.

Kalluri, R., \& Weinberg, R. a. (2009). Review series The basics of epithelialmesenchymal transition. Journal of Clinical Investigation, 119(6), 1420-1428.

Kang, K. a., Lee, K. H., Chae, S., Zhang, R., Jung, M. S., Ham, Y. M., ... Hyun, J. W. (2006). Cytoprotective effect of phloroglucinol on oxidative stress induced cell damage via catalase activation. Journal of Cellular Biochemistry, 97(3), 609-620.

Kang, M.-H., Kim, I.-H., \& Nam, T.-J. (2014a). Phloroglucinol induces apoptosis through the regulation of insulin-like growth factor 1 receptor signaling pathways in human colon cancer HT-29 cells. International Journal of Oncology, 1036-1042. 
Kang, M.-H., Kim, I.-H., \& Nam, T.-J. (2014b). Phloroglucinol induces apoptosis via apoptotic signaling pathways in HT-29 colon cancer cells. Oncology Reports, 13411346.

Karakas, B., Bachman, K. E., \& Park, B. H. (2006). Mutation of the PIK3CA oncogene in human cancers. British Journal of Cancer, 94(4), 455-459.

Kassie, F., Parzefall, W., \& Knasmüller, S. (2000). Single cell gel electrophoresis assay: a new technique for human biomonitoring studies. Mutation Research, 463(1), 13-31.

Key, T. J., Schatzkin, A., Willett, W. C., Allen, N. E., Spencer, E. A., \& Travis, R. C. (2004). Diet, nutrition and the prevention of cancer. Public Health Nutrition, 7(1A), 187-200.

Kerr, J. F. R., Wyllie, A. H., \& Currie, A. R. (1972). Apoptosis: A Basic Biological Phenomenon with Wide-ranging Implications in Tissue Kinetics.British Journal of Cancer, 26(4), 239-257.

Kim, E. K., \& Choi, E. J. (2010). Pathological roles of MAPK signaling pathways in human diseases. Biochimica et Biophysica Acta, 1802(4), 396-405.

Krämer, a, Neben, K., \& Ho, a D. (2002). Centrosome replication, genomic instability and cancer. Leukemia: Official Journal of the Leukemia Society of America, Leukemia Research Fund, U.K, 16(5), 767-775.

Lin, J. E., Li, P., Snook, A. E., Schulz, S., Dasgupta, A., Hyslop, T. M., Gibbons, A. V., Marszlowics, G., Pitaria, G. M., Waldman, S. A. (2010). The hormone receptor GUCY2C suppresses intestinal tumor formation by inhibiting AKT signaling. Gastroenterology, 138(1), 241.

Loeb, L. a. (1991). Mutator phenotype may be required for multistage carcinogenesis. Cancer Research, 51(12), 3075-3079.

Longley, D. B., Harkin, D. P., \& Johnston, P. G. (2003). 5-Fluorouracil: Mechanisms of Action and Clinical Strategies. Nature Reviews. Cancer, 3(5), 330-338.

Lopes, G. (2014). Seaweeds from the Portuguese Coast: Chemistry, Antimicrobial and Anti-inflammatory Capacity.

López-Lázaro, M. (2015). Two preclinical tests to evaluate anticancer activity and to hel validate drug candidates for clinical trials. Oncoscience, 2(2), 91-98.

Lopiccolo, J., Blumenthal, G. M., Bernstein, W. B., \& Dennis, P. a. (2008). Targeting the PI3K/Akt/mTOR pathway: effective combinations and clinical considerations. Drug Resist, 11(301), 32-50.

Lomonosova, E., \& Chinnadurai, G. (2008). BH3-only proteins in apoptosis and beyond: an overview. Oncogene, 27 Suppl 1(S1), S2-S19.

Löwenberg, B., Pabst, T., Vellenga, E., van Putten, W., Schouten, H. C., Graux, C., Ossenkoppele, G. J. (2011). Cytarabine dose for acute myeloid leukemia. The New England Journal of Medicine, 364(11), 1027-1036.

Ma, Q., \& Lu, Y. H. (2011). Pharmacogenetics, Pharmacogenomics, and Individualized Medicine. Pharmacological Reviews, 63(2), 437-440. 
MacDonald, B. T., Tamai, K., \& He, X. (2009). Wnt/ $\beta$-catenin signaling: components, mechanisms, and diseases. Developmental Cell, 17(1), 9-26.

Mahmood, T., \& Yang, P.-C. (2012). Western Blot: Technique, Theory, and Trouble Shooting. North American Journal of Medical Sciences, 4(9), 429-434.

Markowitz, S. D., Bertagnolli, M. M. (2009). Molecular origins of cancer: Molecular basis of colorectal cancer. The New England Journal of Medicine, 361(25), 2449-2460.

Mclntosh, J. M., Dowell, C., Watkins, M., Garrett, J. E., Yoshikami, D., \& Olivera, B. M. (2002). Alpha-conotoxin GIC from Conus geographus, a novel peptide antagonist of nicotinic acetylcholine receptors. The Journal of Biological Chemistry, 277(37), 336105 .

Micalizzi, D. S., Farabaugh, S. M., \& Ford, H. L. (2010). Epithelial-Mesenchymal Transition in Cancer: Parallels Between Normal Development and Tumor Progression. Journal of Mammary Gland Biology and Neoplasia,15(2), 117-134.

Molina, J. R., \& Adjei, A. A. (2006). The Ras / Raf / MAPK Pathway. Journal Thoracic Oncology., 1(1), 7-9.

Mosmann, T. (1983). Rapid colorimetric assay for cellular growth and survival: application to proliferation and cytotoxicity assays. Journal of Immunological Methods, 65(1-2), 55-63.

National Cancer Institute. (n.d.). Retrieved June 13, 2015, from http://www.cancer.gov/types/colorectal

Negrini, S., Gorgoulis, V. G., \& Halazonetis, T. D. (2010). Genomic instability--an evolving hallmark of cancer. Nature Reviews. Molecular Cell Biology, 11(3), 220-228.

O'Donovan, P. J., \& Livingston, D. M. (2010). BRCA1 and BRCA2: Breast/ovarian cancer susceptibility gene products and participants in DNA double-strand break repair. Carcinogenesis, 31(6), 961-967.

Ostling, O. \& Johanson, K. J. (1984). Microelectrophorect study of radiation-induced DNA damage in individual mammalian cells. Biochemistry Biophysics Research Communications, 123, 291-298.

Panda, D., Jordan, M. a., Chu, K. C., \& Wilson, L. (1996). Differential Effects of Vinblastine on Polymerization and Dynamics at Opposite Microtubule Ends. Journal of Biological Chemistry, 271(47), 29807-29812.

Peng, J., Yuan, J. P., Wu, C. F., \& Wang, J. H. (2011). Fucoxanthin, a marine carotenoid present in brown seaweeds and diatoms: Metabolism and bioactivities relevant to human health. Marine Drugs, 9(10), 1806-1828.

Pino, M. S., \& Chung, D. C. (2010). The Chromosomal Instability Pathway in Colon Cancer. Gastroenterology, 138(6), 2059-2072.

Raja, A., Vipin, C., Aiyappan, A. (2013). Review Article Biological importance of Marine Algae- An overview. International Journal of Current Microbiology and Applied Sciences, 2(5), 222-227.

Renehan, a G., Booth, C., \& Potten, C. S. (2001). What is apoptosis, and why is it important? Bristh Medical Journal (Clinical Research Ed.), 322(7301), 1536-1538. 
Rosen, L. S. (2005). VEGF-Targeted Therapy: Therapeutic Potential and Recent Advances. The Oncologist, 10, 288-290.

Saraste, A., \& Pulkki, K. (2000). Morphologic and biochemical hallmarks of apoptosis. Cardiovascular Research, 45(3), 528-537.

Santarpia, L. L., Lippman, S., \& El-Naggar, A. (2012). Targeting the Mitogen-Activated Protein Kinase RAS-RAF Signaling Pathway in Cancer Therapy. Expert Opin Ther Targets, 16(1), 103-119.

Schlessinger, J. (2000). Cell Signaling by Receptor Tyrosine Kinases A large group of genes in all eukaryotes encode for. Cell Press, 103(2), 211-225.

Schwitalla, S., Ziegler, P. K., Horst, D., Becker, V., Kerle, I., Begus-Nahrmann, Y., L, A., Rudolph, K. L., Langer, R., Slotta-Huspenina, J., Bader, F. G., Prazeres da Costa, O., Neurath, M. F., Meining, A., Kirchne, T., Greten, F. R. (2013). Loss of p53 in Enterocytes Generates an Inflammatory Microenvironment Enabling Invasion and Lymph Node Metastasis of Carcinogen-Induced Colorectal Tumors. Cancer Cell, 23(1), 93-106.

Shen, Z. (2011). Genomic instability and cancer: an introduction. Journal of Molecular Cell Biology, 3 (1), 1-3.

Simmons, T. L., Andrianasolo, E., McPhail, K., Flatt, P., \& Gerwick, W. H. (2005). Marine natural products as anticancer drugs. Molecular Cancer Therapeutics, 4(2), 333-342.

Słoczyńska, K., Powroźnik, B., Pękala, E., \& Waszkielewicz, A. M. (2014). Antimutagenic compounds and their possible mechanisms of action. Journal of Applied Genetics, 55(2), 273-85.

Sudhakar, A. (2010). History of Cancer, Ancient and Modern Treatment Methods Akulapalli. Journal Cancer Science \& Therapy., 1(2), 1-4.

Sugawara, T., Baskaran, V., Tsuzuki, W., \& Nagao, A. (2002). Brown algae fucoxanthin is hydrolyzed to fucoxanthinol during absorption by Caco-2 human intestinal cells and mice. The Journal of Nutrition, 132(5), 946-951.

Takaichi, S. (2011). Carotenoids in Algae: Distributions, biosyntheses and functions of carotenoids in algae. Marine Drugs, 9(6), 1101-1118.

Takahashi, K., Hosokawa, M., Kasajima, H., Hatanaka, K., Kudo, K., Shimoyama, N., \& Miyashita, K. (2015). Anticancer effects of fucoxanthin and fucoxanthinol on colorectal cancer cell lines and colorectal cancer tissues. Oncology Letters, 1463-1467.

Taylor, R. C., Cullen, S. P., \& Martin, S. J. (2008). Apoptosis: controlled demolition at the cellular level. Nature Reviews. Molecular Cell Biology, 9(3), 231-241.

Towbin, H., Staehelin, T., \& Gordon, J. (1979). Electrophoretic transfer of proteins from polyacrylamide gels to nitrocellulose sheets: procedure and some applications. Proceedings of the National Academy of Sciences of the United States of America, 76(9), 4350-4354. 
Vara, J. Á. F., Casado, E., de Castro, J., Cejas, P., Belda-Iniesta, C., \& GonzálezBarón, M. (2015). PI3K/Akt signalling pathway and cancer. Cancer Treatment Reviews, 30(2), 193-204.

Walton, M., Sirimanne, E., Reutelingsperger, C., Williams, C., Gluckman, P., \& Dragunow, M. (1997). Annexin $V$ labels apoptotic neurons following hypoxia-ischemia. NeuroReport, 8(18).

Wijesinghe, W. a J. P., Ko, S. C., \& Jeon, Y. J. (2011). Effect of phlorotannins isolated from Ecklonia cava on angiotensin l-converting enzyme (ACE) inhibitory activity. Nutrition Research and Practice, 5(2), 93-100.

Xiang, B., Snook, A. E., Magee, M. S., Waldman, S. A. (2013). Colorectal Cancer Immunotherapy. Discovery Medicine, 15(84), 301-308.

Xu, J., \& Attisano, L. (2000). Mutations in the tumor suppressors Smad2 and Smad4 inactivate transforming growth factor beta signaling by targeting Smads to the ubiquitinproteasome pathway. Proceedings of the National Academy of Sciences of the United States of America, 97(9), 4820-4825.

Zhang, N., Yin, Y., Xu, S. J., \& Chen, W. S. (2008). 5-Fluorouracil: Mechanisms of resistance and reversal strategies. Molecules, 13(8), 1551-1569. 
CHAPTER II - ANTICANCER EFFECTS OF THE SEAWEED COMPOUNDS FUCOXANTHIN AND PHLOROGLUCINOL, ALONE AND IN COMBINATION WITH 5-FLUOROURACIL IN COLON CELLS 


\title{
ANTICANCER EFFECTS OF THE SEAWEED COMPOUNDS FUCOXANTHIN AND PHLOROGLUCINOL, ALONE AND IN COMBINATION WITH 5-FLUOROURACIL IN COLON CELLS
}

\author{
E. Lopes-Costa ${ }^{1,2}$, M. Abreu ${ }^{1}$, D. Gargiulo ${ }^{1,3}$, E. Rocha ${ }^{1,2 \#_{*}}$, A.A. Ramos ${ }^{1,2 \#}$ \\ ${ }^{1}$ ICBAS - Institute of Biomedical Sciences Abel Salazar, University of Porto (U. Porto), \\ Rua de Jorge Viterbo Ferreira, $n^{\circ} 228,4050-313$ Porto, Portugal \\ ${ }^{2}$ CIIMAR - Interdisciplinary Center for Marine and Environmental Research, University \\ of Porto ( $U$. Porto), Group of Histomorphology, Physiopathology, and Applied \\ Toxicology, Rua dos Bragas, n² 289, 4050-123 Porto, Portual. \\ ${ }^{3}$ UNIBH - University Center of Belo Horizonte, University of Minas Gerais, Avenida \\ Professor Mário Werneck, 1685 - Estoril, Belo Horizonte - MG, 30455-610, Brazil \\ \# Joint last authors.
}

* Corresponding author: Eduardo Rocha, Laboratory of Histology and Embryology, Institute of Biomedical Sciences Abel Salazar (ICBAS), University of Porto (U. Porto), Rua de Jorge Viterbo Ferreira $n^{\circ}$. 228, 4050-313 Porto, Portugal. E-mail address: erocha@icbas.up.pt. Tel.:+351-220-428-000 (ext. 5245). 


\section{Abstract}

Colorectal cancer is the third most common cancer and is considered the major cause of morbidity and mortality worldwide. 5-fluorouracil (5-Fu) is one of the most commonly used chemotherapeutic drugs in colorectal cancer. However, resistance to 5 -Fu during treatment is one of the undesirable effects and may emerge due to several mechanisms. Fucoxanthin is a carotenoid present in marine brown seaweeds and microalgae diatoms. Also present in marine brown seaweeds is phloroglucinol, a polyphenolic compound. In the present study, the anticancer activities of fucoxanthin and phloroglucinol alone and in combination with 5-Fu on HCT-116 and HT-29 colorectal cancer cell lines were examined, resorting to anti-proliferative, apoptotic, and genotoxic assays. To assess the specificity of these compounds, the effects on normal colon cell line, CCD-18co, was also assessed. The results indicated that HCT-116 is more sensitive to 5-Fu than HT-29 cells. Also the cytotoxic effects of fucoxanthin were higher in HCT-116 cells increasing DNA damage and apoptosis with enhanced p53 expression and decrease of antiapoptotic proteins, while phloroglucinol decreased cell viability in the same way in both cell lines with induction of apoptosis. Fucoxanthin (in HCT-116 and HT-29 cells) and phloroglucinol (in HT- 29 cells) potentiate the cytotoxic effect of $5-\mathrm{Fu}$ with apoptosis induction. At effective concentrations fucoxanthin and phloroglucinol did not induce cytotoxic effects in normal cells. These findings indicate that fucoxanthin allied to 5 -Fu can be considered as a potential therapeutic treatment in colorectal cancer. Phloroglucinol alone also decreases cell viability and in combination increases the sensitivity to 5-Fu, especially in the p53 mutant HT-29 cancer cell line. Nonetheless, at lower concentrations it inhibits the effects of 5-Fu in HCT-116 cells, which is not desired during a cancer treatment.

\section{Keywords}

5-Fu; anticancer activity; cytotoxicity; fucoxanthin; colon cancer cell lines; phloroglucinol 


\section{Introduction}

Colorectal cancer is the third most common cancer and is considered the major cause of morbidity and mortality worldwide (Haggar \& Boushey, 2009). According to Globocan, almost $55 \%$ of cases occur in developed regions, particularly due to lifestyle, eating habits and environmental conditions of these regions (Haggar \& Boushey, 2009; Globocan, 2012). Currently, treatment for colorectal cancer involves the combination of surgery with chemotherapy, by administration of cytotoxic drugs and radiation. 5fluorouracil $(5-\mathrm{Fu})$, an antimetabolite, is one of the most commonly used chemoterapeutic drugs to treat many types of cancer, including colorectal cancer (Bracht et al., 2010).

Apoptosis or programmed cell death is a highly regulated mechanism that works normally during development and aging, acting like a homeostatic mechanism to maintain normal cell populations in tissues (Elmore, 2007). During a cancer development, cancer cells can evade apoptosis, along with the ability to acquire other biological capabilities, leading to uncontrolled cell growth and invasiveness (Hanahan \& Weinberg, 2011). Apoptosis is characterized by cell shrinkage, membrane blebbing, chromatin condensation and nuclear fragmentation, which eliminates aged or damaged cells without causing injury to surrounding tissues (Taylor et al., 2008). 5-Fu is able to induce apoptosis in human colon cancer cells (Nita el al., 1998; Li et al., 2009). However, development of 5-Fu resistance and some side effects may emerge during treatment, namely bleeding, hair loss, diarrhea, and immunosuppression (Grem, 2000; Zhang et al., 2008; Focaccetti et al., 2015).

In the last decades, the research of bioactive compounds, with potential antitumor activity, in different marine organisms (e.g. marine algae, sponges, corals) has been highly exploited. Screening for natural compounds able of inducing apoptosis in cancer cells that can work alone or in combination with other chemotherapeutic drugs is now one of the main focus in investigation, in order to increase the therapeutic efficacy and reduce the side effects in cancer therapy (Ji et al., 2009). Since ancient times marine algae have been used in human diets and in traditional medicine namely in China, Japan and the Republic of Korea. In the last decades, we have witnessed an increase of algae consumption in Europe and in other parts of the world through the inclusion of new eating habits (McHugh, D. J., 2003; Burtin, 2003; Vigani et al., 2015). Several studies showed a link between consumption of marine algae and healthy life 
expectancy (Maeda et al., 2005; Jin et al., 2006; Nakashima et al., 2009; Lee \& Jeon, 2013).

Marine algae are a magnificent source of bioactive compounds which have demonstrated a broad range of biological activities such as antioxidant, antimicrobial, anti-inflammatory and anticancer activities (Raja et al., 2013; Lee et al., 2013). Fucoxanthin, a marine carotenoid, can be found in marine brown seaweeds (Phaeophyceae) and microalgae diatoms (Bacillariophyta). The chemical structure of fucoxanthin includes an allelic bond and some oxygenic functional groups, such as epoxy, hydroxyl, carbonyl and carboxyl groups enabling it with a potent free radical scavenging activity (Peng et al., 2011). Besides its antioxidant activity, fucoxanthin has anti-inflammatory, anticancer and antidiabetic activities showing no adverse effects in some normal cells in vitro and in vivo models (Peng et al., 2011; Kumar et al., 2013; Moghadamtousi et al., 2014). Phloroglucinol is a polyphenolic compound with an aromatic phenyl ring and three hydroxyl groups present in brown algae. Several sorts of biological activities have been described specifically in the medical fields of cardiovascular diseases, diabetes, allergy and cancer (Singh et al., 2009; Lee et al., 2013).

The aim of this study was to assess the in vitro anticancer activity of fucoxanthin and phloroglucinol alone and in combination with a well-known chemotherapeutic drug, 5-Fu, on two human colorectal cancer cell lines (HCT-116 and HT-29) and on a normal human colon cell line (CCD-18Co).

\section{Materials and methods}

\subsection{Chemicals and antibodies}

5-fluorouracil (5-Fu), phloroglucinol, fucoxanthin, Dulbecco's modified Eagle's medium (DMEM), Roswell Park Memorial Institute (RPMI), sodium pyruvate, sodium bicarbonate, N-(2-hydroxyethyl)piperazine-N'-(2-ethanesulfonic acid) (HEPES), penicillin/

streptomycin, trypsin solution, 3-(4,5-dimethylthiazolyl-2)-2,5-diphenyltetrazolium bromide (MTT) and 4',6-diamidino-2-phenylindole (DAPI) were purchased from SigmaAldrich (St. Loius, MO, USA). Fetal bovine serum (FBS) was purchased from Biochrom KG (Berlin, Germany). The protein quantification BCA protein assay kit was purchased from Thermo Fisher Scientific Inc. (Waltham, MA, USA). The RIPA Lysis Buffer, 
Tween-20, primary antibodies Bax (N-20): sc-493 (rabbit polyclonal); Bcl2 (C-2): sc7382 (mouse monoclonal); procaspase 9 p-10 (F-7): sc-17784 (mouse monoclonal); caspase 3 (H-277): sc-7148 (rabbit polyclonal); p53 (DO-1): sc-126 (mouse monoclonal); p27 (C-19): sc-528 (rabbit polyclonal); actin (C4): sc-47778 (mouse monoclonal) and secondary antibodies HRP goat anti-mouse and anti-rabbit were purchased from Santa Cruz Biotechnology, Inc. (Santa Cruz, CA, USA). All other chemicals used were of analytical grade.

\subsection{Cell culture}

Two human cancer cell lines and one normal human cell line were used to assess anti-proliferative activity. HT-29 (colorectal adenocarcinoma) and HCT-116 (colorectal carcinoma) were kindly provided by Prof. Carmen Jerónimo from IPO, Porto. CCD-18Co (normal colon) was obtained from American Type Culture Collection (ATCC, USA). HT-29 and CCD-18Co cell lines were maintained as monolayer cultures in DMEM and HCT-116 in RPMI medium, both supplemented with $10 \%$ of fetal bovine serum (FBS) and $1 \%$ of antibiotic solution (100 U/ml penicillin and $100 \mu \mathrm{g} / \mathrm{ml}), 10 \mathrm{mM}$ HEPES and $0.1 \mathrm{mM}$ pyruvate, at $37^{\circ} \mathrm{C}$ in a humidified $5 \% \mathrm{CO}_{2}$ atmosphere. The medium was replaced every two days and cells were trypsinized when nearly confluent.

\subsection{MTT reduction assay}

To assess the effects of fucoxanthin and phloroglucinol alone or combined with $5-\mathrm{Fu}$ on cell viability in colon cells, MTT reduction assay was used. HCT-116, HT-29 and CCD-18Co cells were plated in 96-multiwell culture plates at a density of $1.0 \times 10^{4}$ cells/well and twenty-four hours after plating, three different types of treatments were made: (1) cells were exposed to fucoxanthin or phloroglucinol at different concentrations, alone or combined with 5-Fu (1 - $50 \mu \mathrm{M}$ ), for $48 \mathrm{~h}$ (in HCT-116 and HT-

29 cells) or 72 h (in CCD-18Co cells). Positive and negative controls were performed; (2) cancer cells were incubated with phloroglucinol at different concentrations. After 24 $\mathrm{h}$ of pre-treatment fresh medium containing 5-Fu was added for $48 \mathrm{~h}$; and (3) cancer cells were treated with phloroglucinol or 5-Fu at different concentrations for $48 \mathrm{~h}$, followed by a recovery period ( 24 and $72 \mathrm{~h}$ ) in fresh medium. After the incubation period MTT was added at a final concentration of $0.5 \mathrm{mg} / \mathrm{ml}$ and incubated for $2 \mathrm{~h}$ at 37 ${ }^{\circ} \mathrm{C}$. DMSO: ethanol solution (1:1) (v/v) was added to solubilize formazan crystals and 
absorbance was measured at $570 \mathrm{~nm}$ in a microplate reader (Multiskan EX, Labsystems, USA). The MTT is a colorimetric assay based in the mitochondrial conversion of MTT into formazan crystals by viable cells. Thus, alterations in the absorbance may reflect changes in the number of viable cells. Results are presented as the percentage of cell viability relative to negative control (cells treated only with $0.5 \%$ of DMSO) of at least six independent experiments (each one in duplicate). Morphology alterations of colon cells after treatments were registered under inverted phase contrast microscopy.

\subsection{Comet assay}

To evaluate the genotoxic effect of fucoxanthin, phloroglucinol and 5-Fu, cancer cells were plated $\left(0.1 \times 10^{6}\right.$ cells/well $)$ in 24-multiwell culture plates. Twenty-four hours after plating, cells were incubated with the compounds at different concentrations (1 $300 \mu \mathrm{M}$ ) for $24 \mathrm{~h}$ and DNA damage assessed by alkaline version of the single cell gel electrophoresis assay (also known as comet assay) as described previously (Ramos et al., 2010) with some modifications. Briefly, cells were suspended in low melting point agarose and lysed for $1 \mathrm{~h}$ at $4{ }^{\circ} \mathrm{C}$ and electrophoresis performed at $4{ }^{\circ} \mathrm{C}$ during $20 \mathrm{~min}$ at $21 \mathrm{~V}$. For the analysis of the comets, the slides were stained with DAPI solution (1 $\mu \mathrm{g} / \mathrm{ml}$ ) and examined in a fluorescence microscope (Olympus IX71). Images were analyzed using CometScore ${ }^{\circledR}$ software (CometScore, TriTek Corp.) and the parameter tail intensity (\% DNA in the comet tail in relation to total DNA) was measure. At least 100 selected cells were examined per sample. The results were expressed as $\%$ of DNA in tail of at least three independent experiments.

\subsection{Nuclear Condensation assay}

Nuclear Condensation assay was performed to determine the ability of the compounds to induce cell death. Cancer cells were plated $\left(0.1 \times 10^{6}\right.$ cells/well $)$ in 24multiwell culture plates. After twenty-four hours plating, cells were incubated with the fucoxanthin or phloroglucinol alone or combined with 5-Fu at different concentration for $48 \mathrm{~h}$. Then, both adherent and non-adherent cells were collected, washed, centrifuged, fixed with $4 \%(\mathrm{w} / \mathrm{v})$ paraformaldehyde in PBS, for $20 \mathrm{~min}$ at $37^{\circ} \mathrm{C}$ and attached into a polylysine-treated slide using a Cytospin Cytocentrifuge (Thermo Scientific, USA). Cells were incubated with DAPI $(1 \mu \mathrm{g} / \mathrm{ml})$ and observed in a fluorescence microscope 
(Olympus, Japan). The percentage of cells with condensed nuclei was determined from the ratio between cells with nuclear condensation and total number of cells counted in each sample. More than 300 cells were counted per sample. Results were expressed as $\%$ of cells with condensed nuclei of at least three independent experiments.

\subsection{Western blot}

Effect of fucoxanthin, phloroglucinol alone or combined with 5-Fu in HCT-116 and HT-29 cells on some apoptotic and antiapoptotic proteins were evaluated by western blot. After $48 \mathrm{~h}$ of treatment cells were washed with PBS and lysed with complete RIPA buffer for 15 min on ice. Protein concentration was measured with BCA protein assay using BSA as a protein standard. Equal amount of total protein (60 $\mu \mathrm{g} /$ well) were separated on SDS-PAGE on a $4-20 \%$ gradient polyacrylamide MiniPROTEAN® TGX ${ }^{\mathrm{TM}}$ precast gel (Bio-Rad) and transferred to PVDF membranes of Transblot $^{\circledR}$ turbo $^{\mathrm{TM}}$ Transfer Pack, BioRad. The membrane was blocked at room temperature with $5 \%(\mathrm{w} / \mathrm{v})$ nonfat dry milk in TPBS (PBS with $0.1 \%$ Tween-20). Then the membrane was washed thrice with TPBS and incubated overnight at $4{ }^{\circ} \mathrm{C}$ with the primary antibody, followed by $1 \mathrm{~h}$ incubation with a 1:30000 (v/v) dilution of the appropriate horseradish peroxidase-conjugated secondary antibody. Immunoreactive bands were detected using Clarity $^{\mathrm{TM}}$ Western ECL Substrate (Biorad) under a chemiluminescence detection system LAS 4000 mini (GE Healthcare, United Kindgom). B-actin was used as a load control. Band area intensity was quantified using ImageJ software.

\subsection{Statistical analysis}

Statistical analysis was performed using GraphPad Prism 6.0 software (GraphPad Software, La Jolla, CA, USA). The results are represented as mean \pm standard deviation (SD), from at least 3 and up to 6 independent experiments. Significant differences $(\mathrm{P}<0.05)$ were assessed by one-way or two-way ANOVA, followed by the post-hoc Tukey's multiple comparison test or Dunnett's test, as appropriate. 


\section{Results}

\subsection{Effect of fucoxanthin and phloroglucinol alone and in co-incubation with 5-Fu on cell viability by MTT reduction assay in cancer cells and normal cells}

In order to evaluate the anticancer effects of fucoxanthin and phloroglucinol alone and in combination with 5-Fu, two human cancer cell lines (HCT-116 and HT-29) and one normal colon cell line (CCD-18Co) were used. Effects on cell viability were assessed by MTT assay when cells were in exponential growing phase (data not shown). Three different treatments were performed.

\subsubsection{Effects of fucoxanthin and phloroglucinol alone or combined with 5-Fu}

Human cancer cells and normal cells were incubated with fucoxanthin or phloroglucinol alone or combined with 5-Fu at different concentrations for $48 \mathrm{~h}$ (cancer cells) or $72 \mathrm{~h}$ (normal cells). As shown in the figure 1, 5-Fu, at 10 and $50 \mu \mathrm{M}$, significantly decreased cell viability in HCT-116 (51\% and $68 \%)$ and HT-29 cells (25\% and $45 \%$ ) when compared with the negative control. Fucoxanthin also induced a significant decreased on cell viability in both cell lines (HCT-116 and HT-29) showing a concentration-dependent effect (dark bars). At 50 and $100 \mu \mathrm{M}$, fucoxanthin significantly decreased HCT-116 cell viability in $95 \%$ and $94 \%$ (figure $1 \mathrm{~A}$ ) while in HT-29 cells was $73 \%$ and $76 \%$ (figure $1 \mathrm{~B}$ ), respectively, in relation to the negative control. Fucoxanthin at $10 \mu \mathrm{M}$ also decreased cell viability of HT-29 by $19 \%$ relative to control (figure $1 \mathrm{~B}$ ). 
A
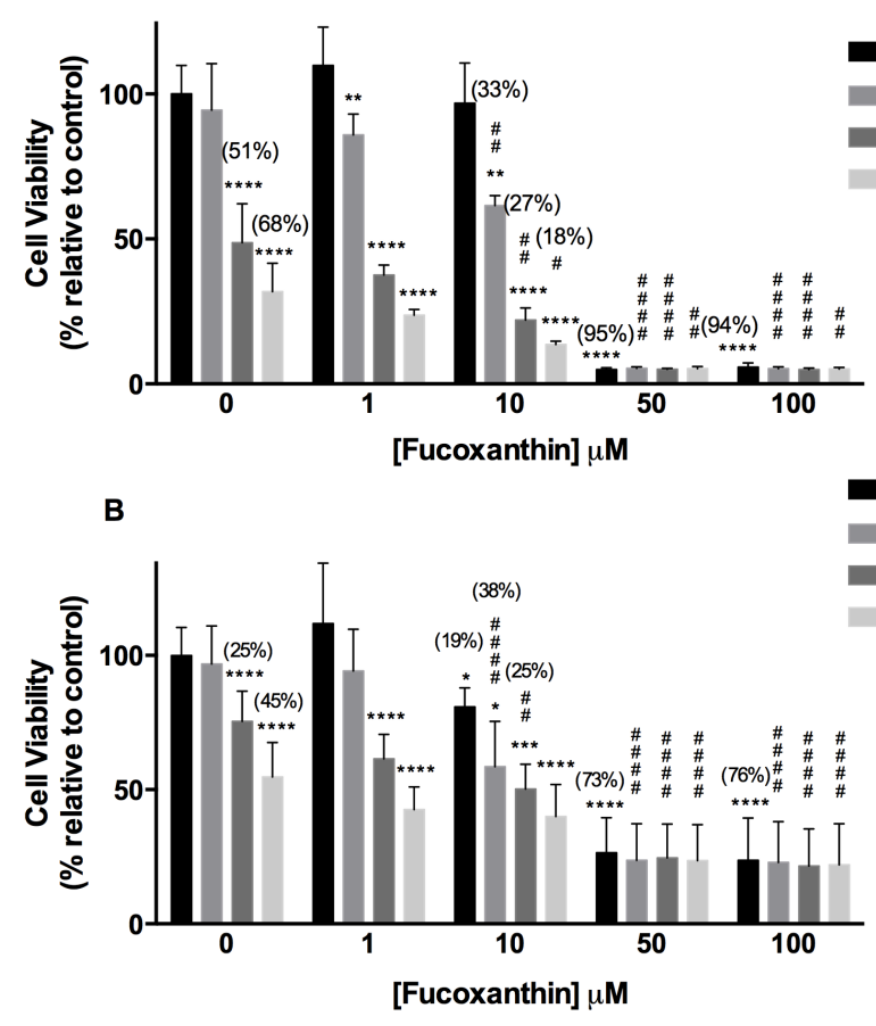

$0 \mu \mathrm{M} 5-\mathrm{Fu}$

$1 \mu \mathrm{M} 5-\mathrm{Fu}$

$10 \mu \mathrm{M} 5-\mathrm{Fu}$

$50 \mu \mathrm{M} 5-\mathrm{Fu}$

Figure 1. Dose-response effects of fucoxanthin alone (dark bars) and in combination with 5-Fu on cell viability in HCT-116 (A) and HT-29 (B) cells after $48 \mathrm{~h}$, evaluated by MTT assay. Results are expressed as mean \pm SD of at least seven independent experiments. Significant differences $\left({ }^{*} P<0.05 ;{ }^{* *} P<0.01 ;{ }^{* * *}\right.$ $\left.\mathrm{P}<0.001 ;{ }^{* * * *} \mathrm{P}<0.0001\right)$ when compared with the respective control (black columns) and $\left({ }^{\#} \mathrm{P}<0.05\right.$; ${ }^{\#}$ $\mathrm{P}<0.01$; \#\#\# $\mathrm{P}<0.0001$ ) when compared with the respective control (cells incubated only with 5-FU), were tested by two-way ANOVA, followed by the post-hoc Tukey's test. Percentages in brackets shows the decrease in relation to respective control.

When analyzed the results of co-incubation of fucoxanthin and 5-Fu a significant decrease on cell viability was observed in both cancer cell lines for some combinations, when compared with the compounds isolated. In HCT-116 cells the combination of fucoxanthin $(10 \mu \mathrm{M})$ plus $5-\mathrm{Fu}(1,10$ and $50 \mu \mathrm{M})$ induced a significant decreased of cell viability in $33 \%, 27 \%$ and $18 \%$ when compared to the treatment with 5-Fu at 1,10 and $50 \mu \mathrm{M}$ alone (figure $1 \mathrm{~A}$ ). In the HT-29 cancer cell line, the combination of fucoxanthin $(10 \mu \mathrm{M})$ plus 5 -Fu $(1$ and $10 \mu \mathrm{M})$ significantly decreased cell viability in $38 \%$ and $25 \%$ when compared to the positive control (cells incubated with $5-\mathrm{Fu}$ at 1 and $10 \mu \mathrm{M}$ alone) (figure $1 \mathrm{~B}$ ). At the highest concentrations tested fucoxanthin (50 and $100 \mu \mathrm{M}$ ) combined with 5-Fu did not changed cell viability, when compared with fucoxanthin alone, since increasing the concentration of 5-Fu cells did not alter their response. 
As shown in figure 2, phloroglucinol at $300 \mu \mathrm{M}$ significantly decreased cell viability in both cancer cell lines. The decrease was around $26 \%$ and $24 \%$ in HCT-116 and HT-29 cells, respectively.
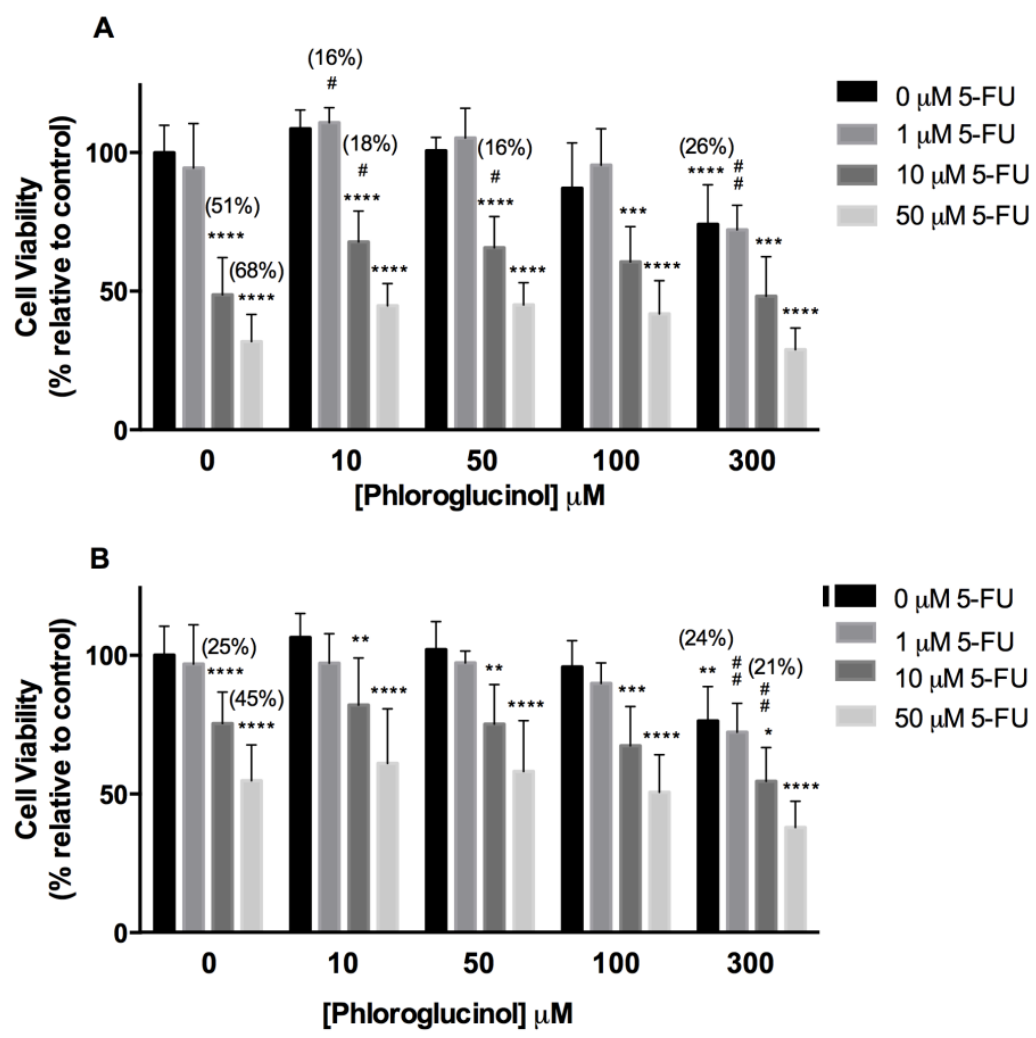

Figure 2. Dose-response effects of phloroglucinol alone and in combination with 5-Fu on cell viability in HCT-116 (A) and HT-29 (B) cells after $48 \mathrm{~h}$, evaluated by MTT assay. Results are expressed as mean \pm $S D$ of at least seven independent experiments. Significant differences $\left({ }^{*} P<0.05 ;{ }^{* *} P<0.01 ;{ }^{* * *} P<0.001\right.$; $\left.{ }^{* * * *} \mathrm{P}<0.0001\right)$ when compared with the respective control (black columns) and $\left({ }^{\#} \mathrm{P}<0.05 ;{ }^{\#} \mathrm{P}<0.01\right)$ when compared with the respective control (cells incubated only with 5-Fu), were tested by two-way ANOVA, followed by the post-hoc Tukey's test. Percentages in brackets shows the decrease and increase in relation to respective control.

Regarding co-incubation, in HCT-116 cells it was observed that phloroglucinol $(300 \mu \mathrm{M})$ increased cytotoxicity of 5 -Fu $(1 \mu \mathrm{M})$ when compared with 5 -Fu alone but no differences were obtained in relation to phloroglucinol at $300 \mu \mathrm{M}$. At low concentrations, phloroglucinol $(10 \mu \mathrm{M})$ plus 5-Fu $(1$ and $10 \mu \mathrm{M})$ and phloroglucinol (50 $\mu \mathrm{M})$ plus $5-\mathrm{Fu}(10 \mu \mathrm{M})$ significantly increased cell viability in $16 \%$ and $18 \%$ when compared with 5-Fu alone (figure $2 \mathrm{~A}$ ). These results highlight a possible protective effect of low concentrations of phloroglucinol against cytotoxicity induced by 5-Fu. However, in HT-29 cancer cell line, phloroglucinol, at $300 \mu \mathrm{M}$, significantly increased the cytotoxicity of $5-\mathrm{Fu}(10 \mu \mathrm{M})$ in $21 \%$ when compared with $5-\mathrm{Fu}(10 \mu \mathrm{M})$ alone (figure 2B). 
The anti-proliferative effect of fucoxanthin and phloroglucinol alone and in coincubation with 5-Fu was also confirmed by a decrease of cell density and by morphological alterations in HCT-116 and HT-29 cell lines, using a phase contrast microscope (data not shown).

To assess the specificity of the antitumor effect of fucoxanthin and phloroglucinol alone and in combination with $5-\mathrm{Fu}$, the conditions described above were tested in a normal colon cell line (CCD-18Co). For the normal cell line, incubation period with the compounds was $72 \mathrm{~h}$, to ensure that the cells had time to divide properly. The results were represented as percentage of cell viability relative to control (cells with $0.5 \%$ DMSO) (figure 3 ).

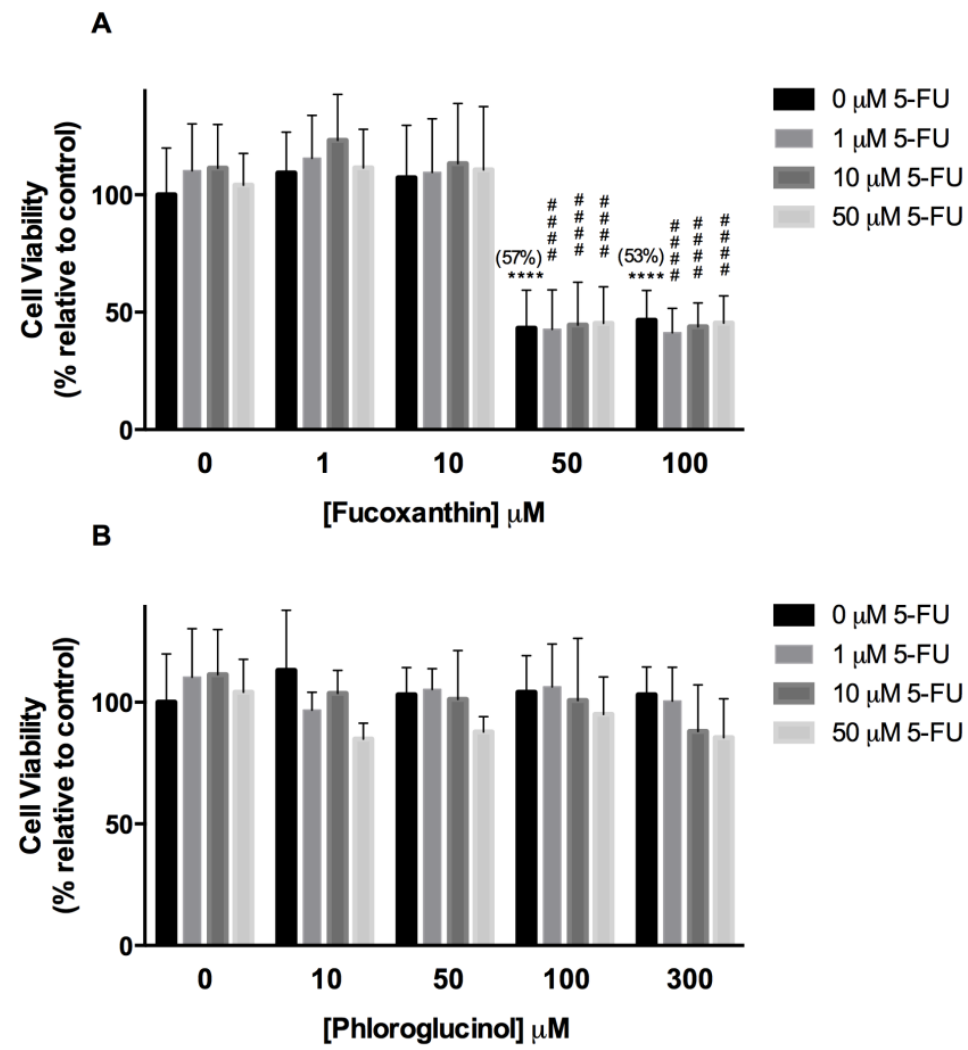

Figure 3. Dose-response effects of fucoxanthin (A) and phloroglucinol (B) alone and in combination with 5Fu on cell viability in CCD-18Co cells after $72 \mathrm{~h}$, evaluated by MTT assay. Results are expressed as mean $\pm S D$ of at least six independent experiments. Significant differences $\left({ }^{* * *} \mathrm{P}<0.0001\right)$ when compared with the respective control (black columns) and ( $\mathrm{P}<0.0001$ ) when compared with the respective control (cells incubated only with 5-FU), were tested by two-way ANOVA, followed by the post-hoc Tukey's test. Percentages in brackets shows the decrease in relation to respective control. 
Unlike what was verified in the two cancer cell lines, in CCD-18Co cells, fucoxanthin below $50 \mu \mathrm{M}$ (alone or in co-incubation with 5-Fu) did not present a significant decrease in cell viability. However, for higher concentrations of fucoxanthin (50 and $100 \mu \mathrm{M}$ ) a significant decrease of cell viability was observed by $57 \%$ and $53 \%$, respectively, when compared with the negative control (figure $3 \mathrm{~A}$ ). These results show that lower concentrations of fucoxanthin are not toxic to normal cells. Regarding the results obtained in the MTT assay, the combination of $10 \mu \mathrm{M}$ fucoxanthin plus 1,10 and $50 \mu \mathrm{M} 5-\mathrm{Fu}$ seems to be more efficient as it potentiates the cytotoxicity of the anticancer drug in cancer cell lines without apparent toxicity to the normal cell line.

With respect to phloroglucinol, no changes were observed on cell viability in all conditions tested (figure 3B). Phloroglucinol alone and in combination with 5-Fu did not induce cytotoxic effects in normal cells. 


\subsubsection{Effect of pre-treatment with phloroglucinol}

The pre-treatment condition, incubation with phloroglucinol for $24 \mathrm{~h}$ followed by incubation with fresh medium containing 5-Fu for $48 \mathrm{~h}$, was performed to evaluate if the low bioactivity of phloroglucinol observed in co-incubation with 5-Fu would be higher in other regimes. The results showed that phloroglucinol, at $300 \mu \mathrm{M}$, significantly decreased viability of HCT-116 cell by $18 \%$ relative to the negative control (figure $4 \mathrm{~A}$ ). However, any of the tested concentrations of phloroglucinol showed a protective/ inductive effect against the toxicity induced by 5-Fu in both cell lines (figure 4).
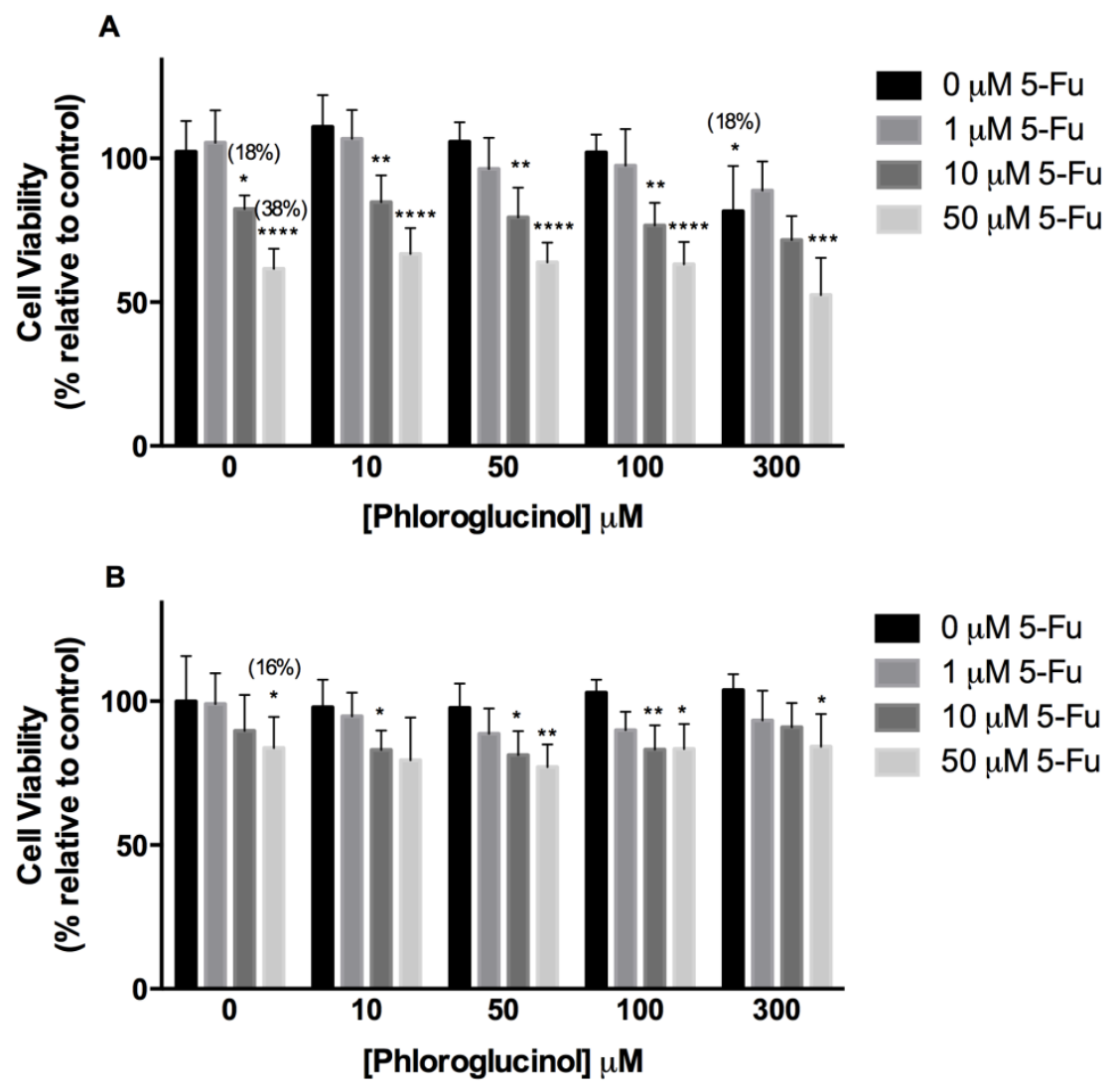

Figure 4. Dose-response effects of pre-treatment with phloroglucinol alone for $24 \mathrm{~h}$, followed by incubation with fresh medium containing 5-Fu for $48 \mathrm{~h}$ on cell viability in HCT-116 (A) and HT-29 (B) cells, evaluated by MTT assay. Results are expressed as mean \pm SD of at least six independent experiments. Significant differences ( $\mathrm{P}<0.05$; ${ }^{* *} \mathrm{P}<0.01 ;{ }^{* * *} \mathrm{P}<0.001$; $\left.{ }^{* * *} \mathrm{P}<0.0001\right)$ when compared with the respective control (black columns), were tested with two-way ANOVA, followed by the post-hoc Tukey's test. Percentages in brackets shows the decrease in relation to respective control. 


\subsubsection{Effect of phloroglucinol after a recovery period}

To assess if the cytotoxicity induced by phloroglucinol and 5-Fu in HCT-116 and HT-29 remains after remove of the compounds, cells were treated with phloroglucinol or $5-\mathrm{Fu}$ at different concentrations for $48 \mathrm{~h}$ followed by a recovery period ( 24 and $72 \mathrm{~h}$ ) in fresh medium.

A

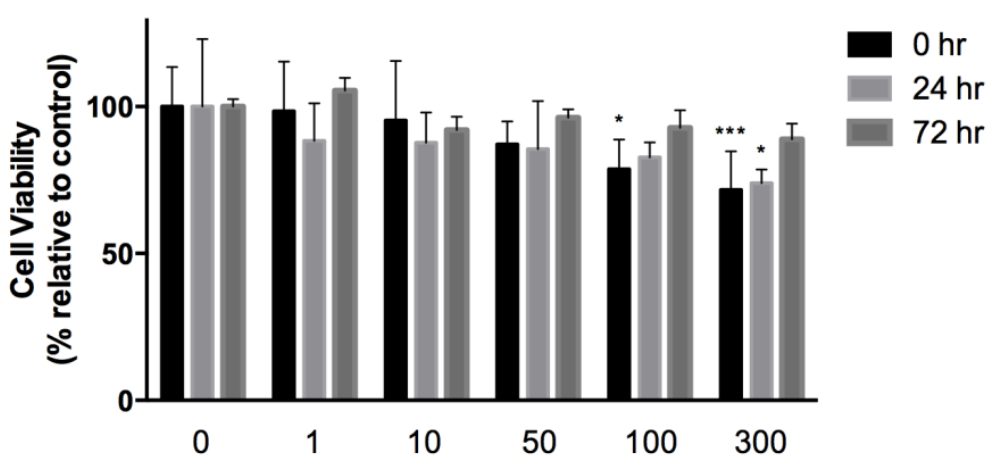

B

[Phloroglucinol] $\mu \mathrm{M}$

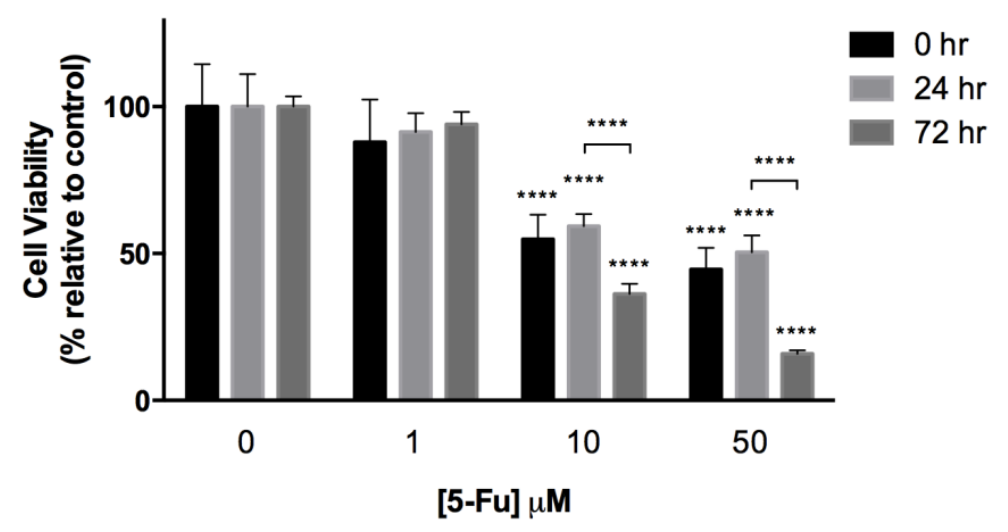

Figure 5. Dose-response effect of phloroglucinol (A) and 5-Fu (B) on cell viability in HCT-116 after $48 \mathrm{~h}$, followed by a recovery period of $24 \mathrm{~h}$ and $72 \mathrm{~h}$, evaluated by MTT assay. Results are expressed as mean $\pm S D$ of at least five independent experiments. Significant differences $\left({ }^{*} P<0.05 ;{ }^{* \star *} P<0.001\right.$; ${ }^{* \star \star *}$ $\mathrm{P}<0.0001$ ) when compared with the respective control, were tested with two-way ANOVA, followed by the post-hoc Tukey's test.

The results presented in figure 5 and figure 6 , showed that phloroglucinol at 300 $\mu \mathrm{M}$ significantly decreased viability of HCT-116 (figure 5A) and HT-29 cells (figure 6A) at $0 \mathrm{~h}$ of recovery. In HCT-116, after $72 \mathrm{~h}$ of recovery in fresh medium was observed a slight increase of cell viability (figure $5 \mathrm{~A}$ ). 
In HT-29 cells, after $24 \mathrm{~h}$ of recovery in fresh medium cell viability significantly increased, demonstrating the recover ability of the HT-29 cancer cell line (figure 6A).

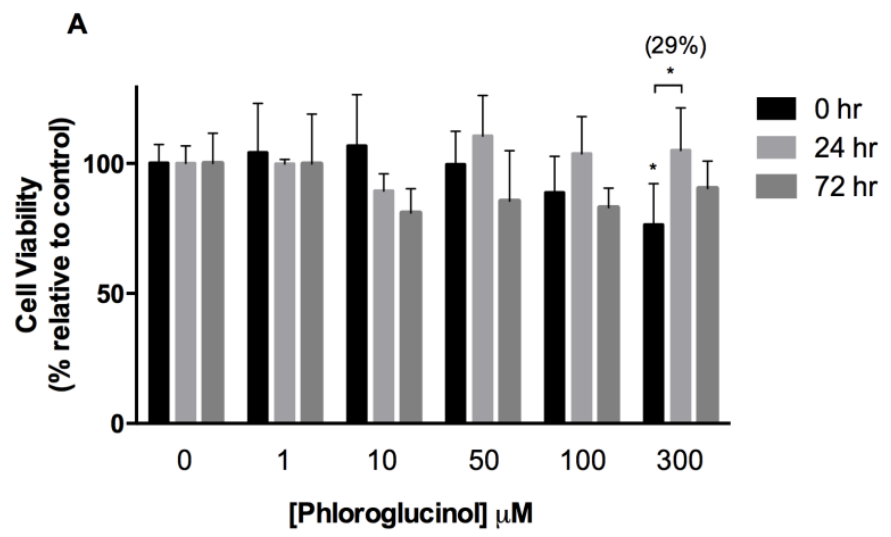

$$
\text { B }
$$

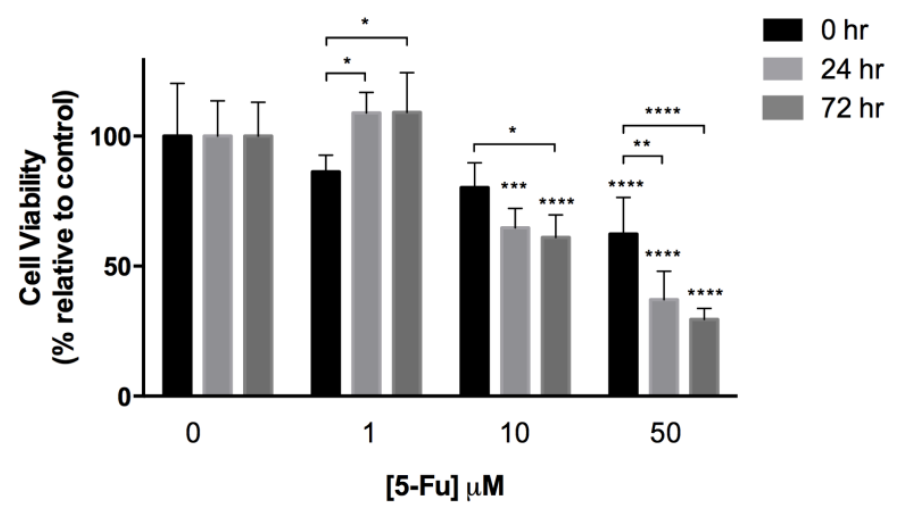

Figure 6. Dose-response effect of phloroglucinol (A) and 5-Fu (B) on cell viability in HT-29 after $48 \mathrm{~h}$ followed by a recovery period of $24 \mathrm{~h}$ and $72 \mathrm{~h}$, evaluated by MTT assay. Results are expressed as mean $\pm S D$ of at least five independent experiments. Significant differences $\left({ }^{*} P<0.05 ;{ }^{* * *} P<0.001 ;{ }^{* * * *}\right.$ $\mathrm{P}<0.0001$ ) when compared with the respective control, were tested with two-way ANOVA, followed by the post-hoc Tukey's test. Percentages in brackets shows the increase in relation to respective control.

Regarding the effects of 5-Fu was observed at 10 and $50 \mu \mathrm{M}$ a significant increase of cytotoxicity after recovery period in HCT-116 (figure 5B) and HT-29 cells (figure 6B). This means that the cytotoxic effect of 5-Fu remains for a long period after its removal from the medium. However, in HT-29 cells treated with 5-Fu at $1 \mu \mathrm{M}$ an increase of cell viability was observed returning to the original values after recovered period (figure 6B). 


\subsection{Effect of fucoxanthin, phloroglucinol and fluorouracil on DNA damage by the comet assay in cancer cell lines}

To assess the genotoxic effect of fucoxanthin and phlorolucinol, HCT-116 and HT-29 cells were exposed at different concentrations of fucoxanthin $(10-100 \mu \mathrm{M})$ or phloroglucinol (10-300 $\mu \mathrm{M})$ for $24 \mathrm{~h}$ and DNA damage assessed by comet assay.

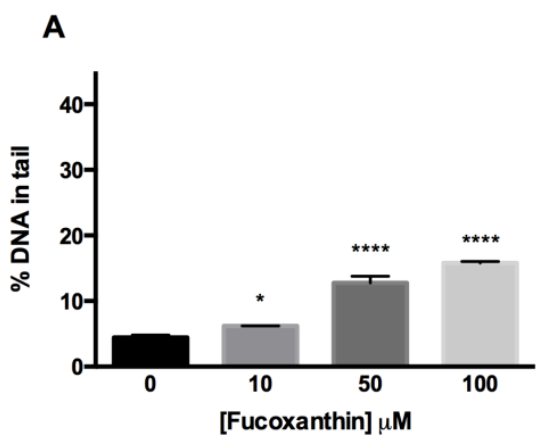

C

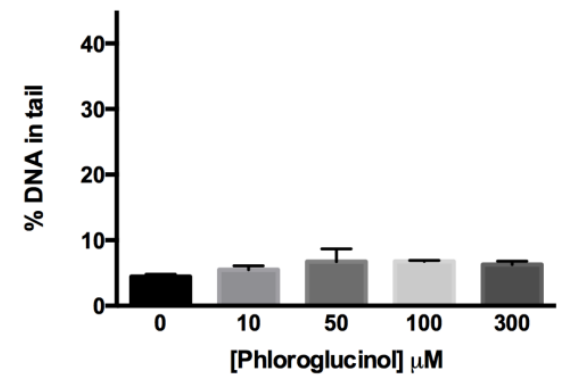

E

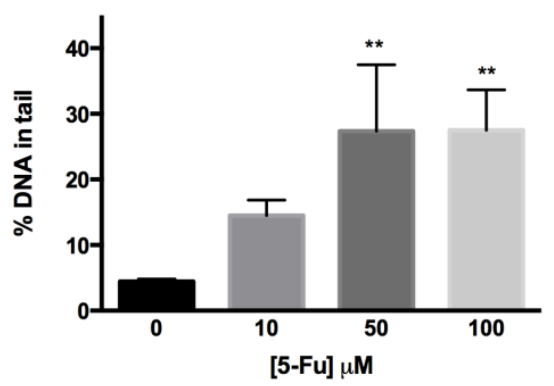

B

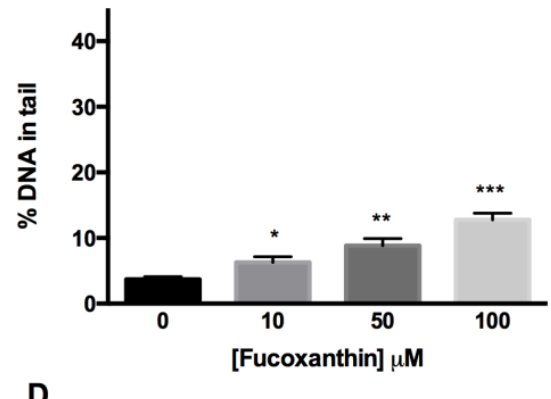

D

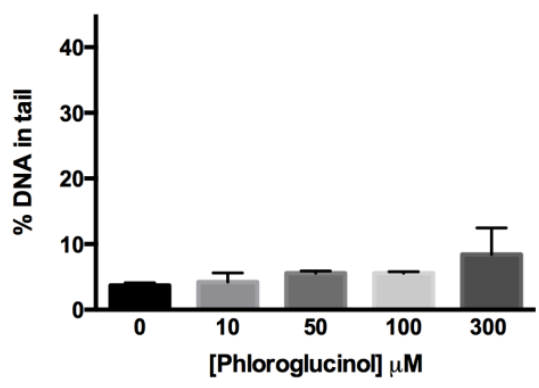

$\mathbf{F}$

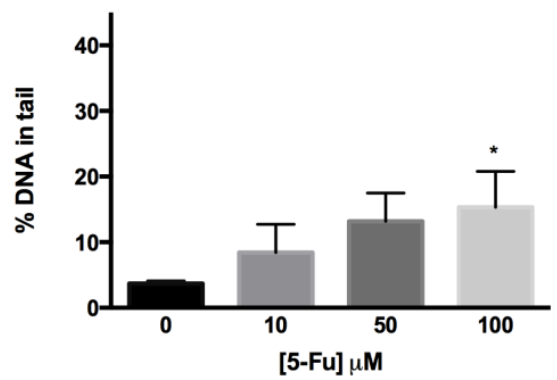

Figure 7. Genotoxic effect of fucoxanthin, in HCT-116 (A) and HT-29 (B), phloroglucinol, in HCT-116 (C) and HT-29 (D) and 5-Fu, in HCT-116 (E) and HT-29 (F) cells after $24 \mathrm{~h}$, evaluated by comet assay. Results are expressed as mean \pm SD of at least three independent experiments. Significant differences (* $\left.\mathrm{P}<0.05 ;{ }^{* *} \mathrm{P}<0.01 ;{ }^{* * *} \mathrm{P}<0.001 ;{ }^{* * * *} \mathrm{P}<0.0001\right)$ when compared with the respective control, were tested with one-way ANOVA, followed by the post-hoc Dunnett's test. 
The results showed that fucoxanthin significantly increased the percentage of DNA in tail in both cell lines in a dose-dependent manner, when compared with the negative control (figure 7A and 7B). Phloroglucinol did not induce DNA damage detectable by the comet assay at any of the tested concentrations in both cancer cell lines (figure 7C and 7D). It was observed that only the highest concentrations tested of 5 -Fu $(50$ and $100 \mu \mathrm{M})$, at $24 \mathrm{~h}$ of incubation, were responsible for a significant increase in the percentage of DNA damage in HCT-116 cells (figure 7E). For HT-29 cells, 5-FU at $100 \mu \mathrm{M}$ significantly increased the percentage of DNA damage (figure 7F).

\subsection{Effect of fucoxanthin and phloroglucinol alone and in co-incubation with 5 -FU on cell death by the nuclear condensation assay in cancer cell lines}

Nuclear chromatin condensation was assessed in the two human cancer cell lines (HCT-116 and HT-29) after $48 \mathrm{~h}$ exposure to fucoxanthin and phloroglucinol alone and in combination with 5-Fu by fluorescence microscopy.

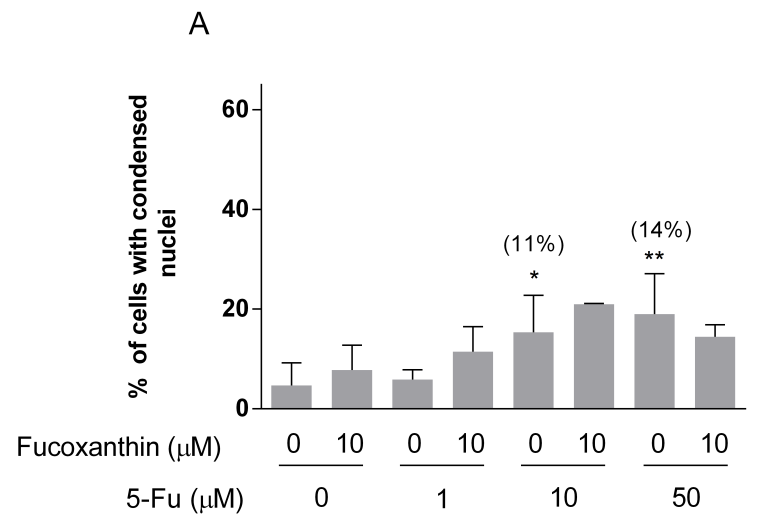

B

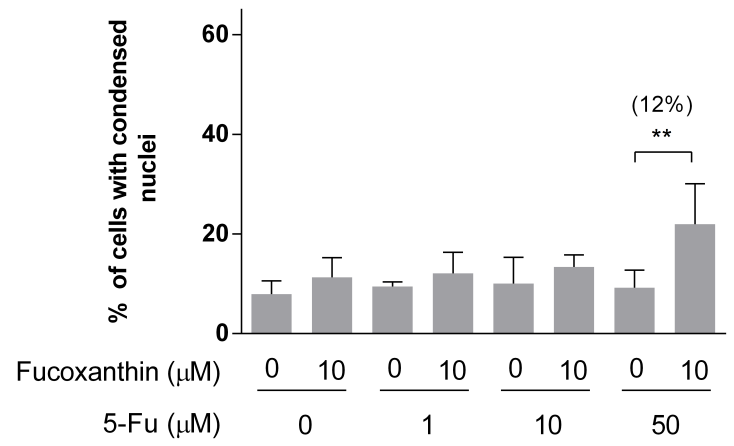

Figure 8. Induction of nuclear condensation by fucoxanthin alone and in co-incubation with 5-Fu, in HCT116 (A) and HT-29 (B) cells after 48 h, evaluated by Nuclear Condensation assay. Results are expressed as mean $\pm S D$ of at least three independent experiments. Significant differences $\left({ }^{*} P<0.05 ;{ }^{* *} P<0.01\right)$ when compared with the respective control, were tested with one-way ANOVA, followed by the post-hoc Tukey' test. Percentages in brackets shows the increase in relation to respective control. 
As shown in figure 8,5-Fu at 10 and $50 \mu \mathrm{M}$ was able to significantly increase the percentage of cells with nuclear condensation by $11 \%$ and $14 \%$, respectively, in HCT-116 (figure 8A). Regarding the results obtained with HT-29 cells, the combination with fucoxanthin $10 \mu \mathrm{M}$ plus $5-\mathrm{Fu}$ at $50 \mu \mathrm{M}$ exhibited a significant increase in the percentage of cells with nuclear condensation by $12 \%$ (figure $8 \mathrm{~B}$ ).

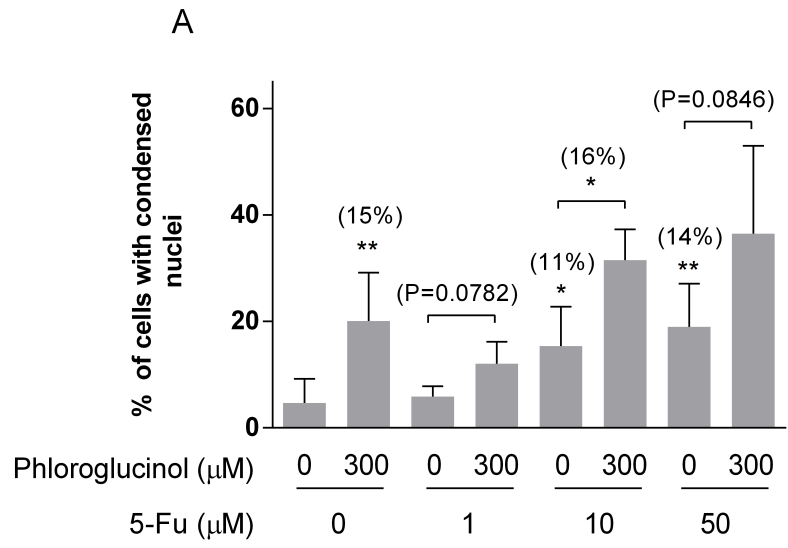

B

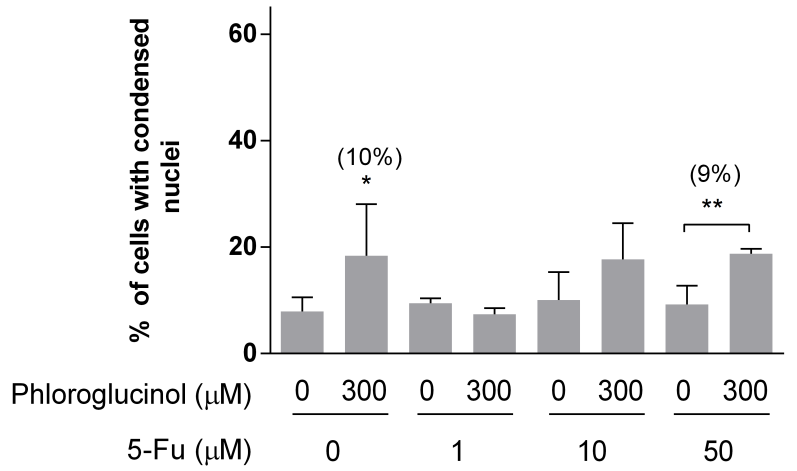

Figure 9. Induction of nuclear condensation by phloroglucinol alone and in co-incubation with $5-\mathrm{Fu}$, in HCT-116 (A) and HT-29 (B) cells after $48 \mathrm{~h}$, evaluated by Nuclear Condensation assay. Results are expressed as mean $\pm S D$ of at least three independent experiments. Significant differences $\left({ }^{\star} P<0.05\right.$; ${ }^{*}$ $\mathrm{P}<0.01)$ when compared with the respective control, were tested with one-way ANOVA. Percentages in brackets shows the increase in relation to respective control.

As shown in figure 9, HCT-116 cells exposed to phloroglucinol at $300 \mu \mathrm{M}$ exhibited a significant increase of $15 \%$, in the percentage of cells with nuclear condensation when compared with the control (figure 9A).

Regarding co-incubation, $300 \mu \mathrm{M}$ phloroglucinol plus $10 \mu \mathrm{M}$ 5-Fu induced a significant increase by $16 \%$, when compared to the treatment with 5 -Fu at $10 \mu \mathrm{M}$ alone. However when in co-incubation with 5-Fu at 1 and $50 \mu \mathrm{M}$, phloroglucinol showed only a tendency to increase the percentage of cells with nuclear condensation (figure 9A). 
Relatively to HT-29 cells, incubation with phloroglucinol at $300 \mu \mathrm{M}$ significantly increased in $10 \%$ the number of cells with nuclear condensation when compared with the control (figure 9B). The combination of phloroglucinol at $300 \mu \mathrm{M}$ plus $5-\mathrm{Fu}$ at $50 \mu \mathrm{M}$ showed a significant increase in the percentage of cells with nuclear condensation by $9 \%$, when compared with $5-\mathrm{Fu}$ at $50 \mu \mathrm{M}$ alone (figure $9 \mathrm{~B}$ ).

\subsection{Effect of fucoxanthin and phloroglucinol alone and in co-incubation with 5-Fu on pro-apoptotic and anti-apoptotic proteins expression by Western blot}

To assess the possible involvement of apoptosis in the antitumor activity of fucoxanthin and phloroglucinol alone and in co-incubation with 5-Fu, the expression of proapoptotic and antiapoptic proteins was assessed in the two human cancer cell lines (HCT-116 and HT-29) after $48 \mathrm{~h}$ exposure (figure 10 and 11).

In HCT-116 cancer cell line, fucoxanthin $(10 \mu \mathrm{M})$ induce p53 expression and decreased $\mathrm{Bcl}-2$ expression when compared with the control (medium with 0.5\% DMSO) (figure 10). No effects were observed in Bax, procaspase 9 and p27 expression. In the case of treatment with 5-Fu at 1 and $10 \mu \mathrm{M}$ an increase of p53 and Bax expression and a decrease of $\mathrm{Bcl}-2$ and procaspase 9 where observed when compared with the control. Fucoxanthin at $10 \mu \mathrm{M}$ plus $1 \mu \mathrm{M} 5$-Fu increased the expression levels of p53, Bax, procaspase 9 and p27 with a slight decrease of Bcl-2 expression, when compared with $5-\mathrm{Fu}$ at $1 \mu \mathrm{M}$. Regarding treatment with phloroglucinol at $10 \mu \mathrm{M}$ an increase of $\mathrm{Bax} / \mathrm{Bcl} 2$ ratio with a decrease of procaspase 9 expression, was observed in HCT116 cells. When in combination with $1 \mu \mathrm{M} 5-\mathrm{Fu}$, phloroglucinol exhibited higher levels of p53, Bcl-2, procaspase 9 and p27 than cells treated with 5-Fu alone. Increasing 5-Fu concentration to $10 \mu \mathrm{M}$, when combined with $10 \mu \mathrm{M}$ phloroglucinol resulted in an increase of Bax and procaspase 9 expression comparing with $10 \mu \mathrm{M}$ of 5-Fu alone. 


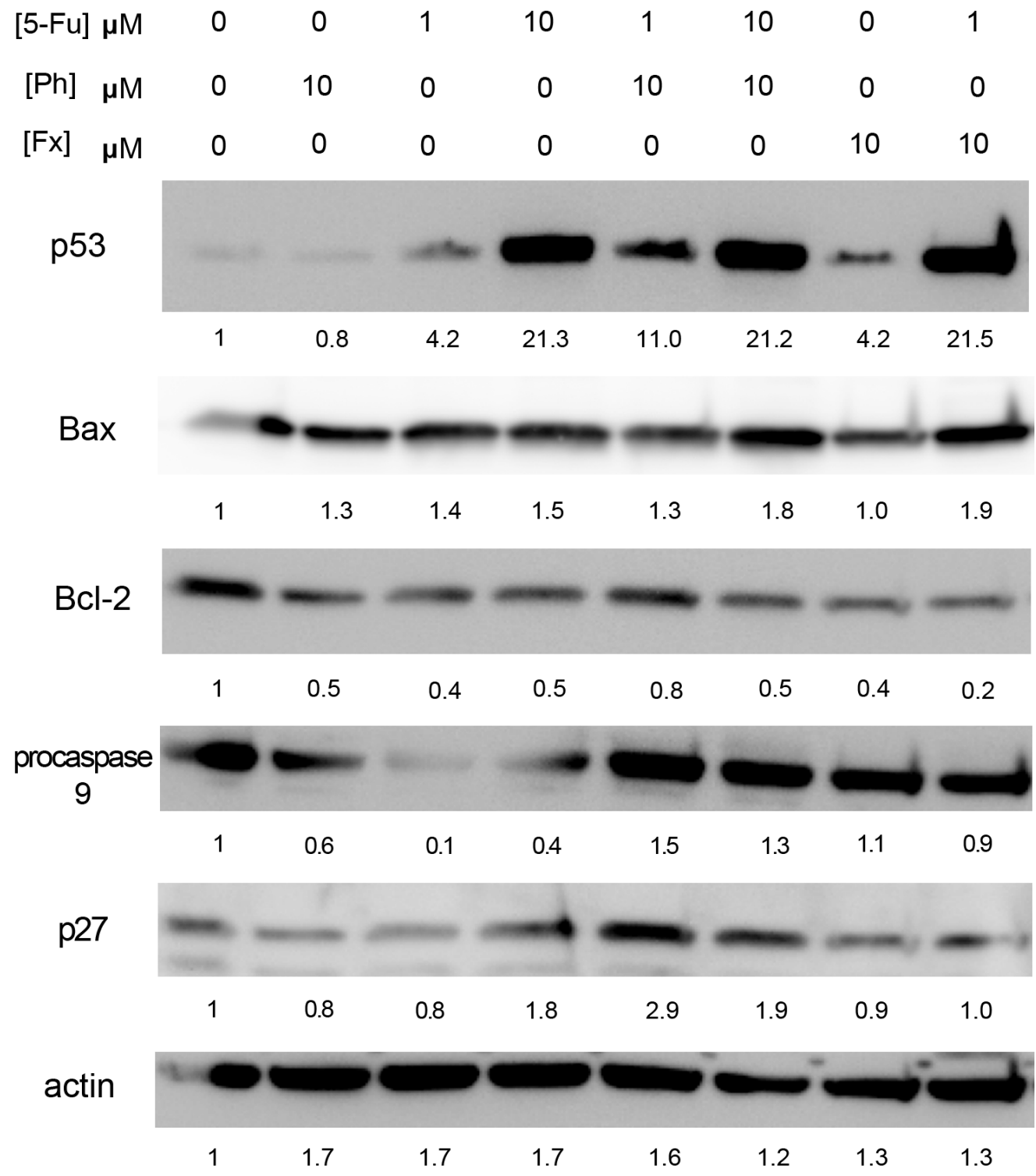

Figure 10. Effects of fucoxanthin and phloroglucinol alone and in co-incubation with 5-Fu, for $48 \mathrm{~h}$, on p53, Bax, Bcl-2, procaspase 9 and p27 expressions in HCT-116 cells by western blot. Images are representative of two independent experiments. The values below the representative blot correspond to its relative quantification using ImageJ software.

In HT-29 cells, treatment with fucoxanthin at $10 \mu \mathrm{M}$ induced the expression of Bax and decreased the expression of procaspase 9 when compared to the control (medium with $0.5 \%$ DMSO) (figure 11). Incubation with 5-Fu at 1 and $10 \mu \mathrm{M}$ decreased the expression of Bax, procaspase 9 and p27 in HT-29 cells. Fucoxanthin at $10 \mu \mathrm{M}$ combined with 5-Fu at $1 \mu \mathrm{M}$ increased Bax and p27 expression compared with 5-Fu alone. Relatively to phloroglucinol at $300 \mu \mathrm{M}$, no significant changes were observed in 
the protein levels. However when in co-incubation with $5-\mathrm{Fu}$ at $10 \mu \mathrm{M}$ a slight increase of Bax and p27 expression was observed when compared with 5-Fu alone.

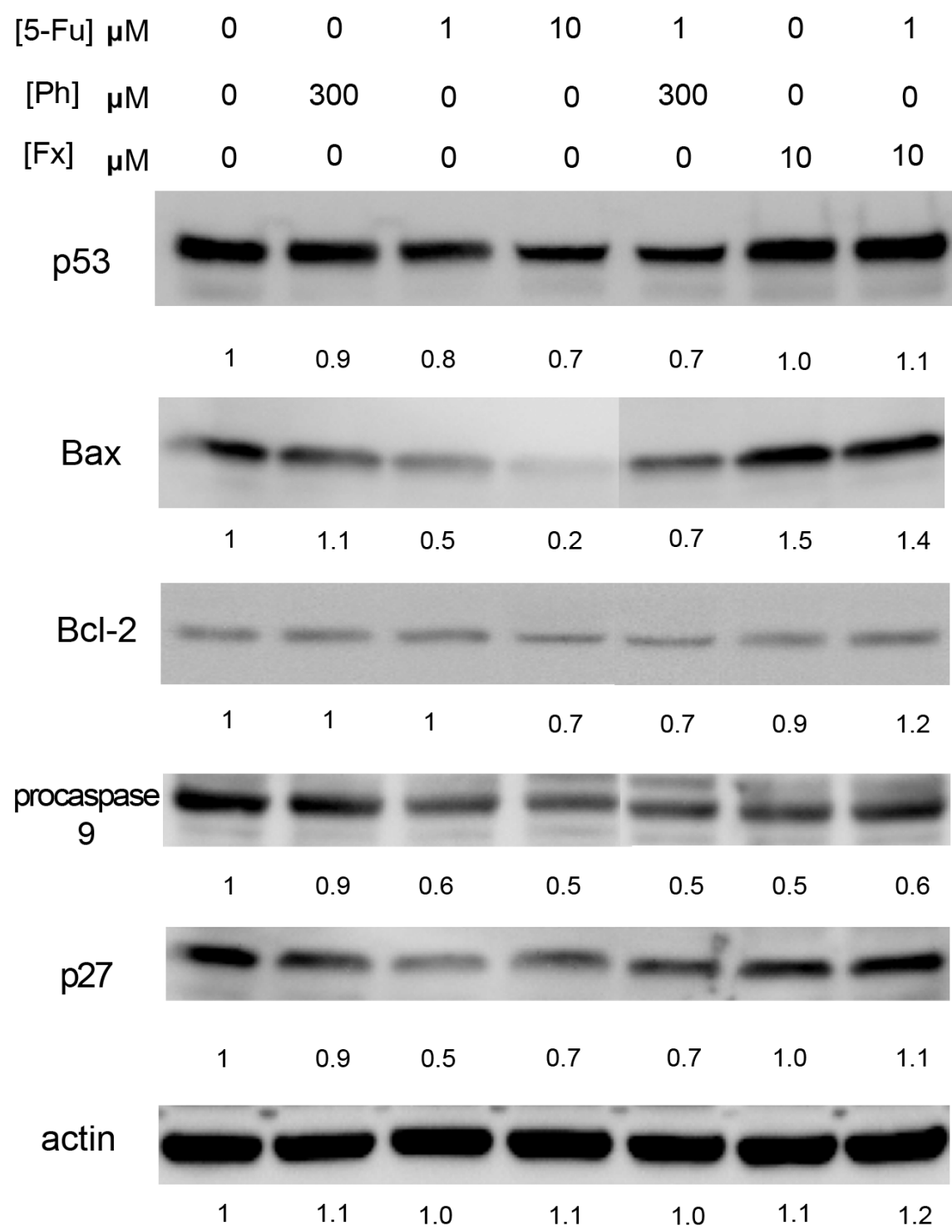

Figure 11. Effects of fucoxanthin and phloroglucinol alone and in co-incubation with 5 -Fu, for $48 \mathrm{~h}$, on p53, Bax, Bcl-2, procaspase 9 and p27 expressions in HT-29 cells by western blot. Images are representative of two independent experiments. The values below the representative blot correspond to its relative quantification using ImageJ software. 


\section{DISCUSSION}

Currently, $5-\mathrm{Fu}$ is one of the most used chemotherapeutic drugs to treat many types of cancer and particularly colorectal cancer. Unfortunately, resistance to 5-Fu may occur during treatment due to several biological mechanisms, namely over expression of thymidylate synthase (TS) and alterations in apoptotic pathway (Zang et al., 2008). Attending these limitations, combination with other drugs and/or natural compounds has been emerging as a new and promising strategy.

Both fucoxanthin as well as phloroglucinol, have shown several biological activities, including cytotoxic effects against cancer cell lines, which are reported in several studies (Zhang et al., 2008; Kong et al., 2009; Liu et al., 2009; Yu et al., 2011). In the present study, the anticancer effects of fucoxanthin and phloroglucinol alone or combined with 5-Fu were assessed on two colorectal cancer cell lines (HCT-116 and HT-29). To evaluate the specificity of the anticancer effect, a normal colon cell line (CCD-Co18) was also tested. Our results showed that 5-Fu decreased cell viability in a dose-dependent manner with the ability to induce DNA damage in both tested cell lines. However, an increase of nuclear condensation was only observed in HCT-116 cells with an increase of $\mathrm{p} 53$ and $\mathrm{Bax} / \mathrm{Bcl}-2$ ratio with a decrease of procaspase 9. Comparing the two cell lines, different susceptibility to 5-Fu was observed, HT-29 cells were more resistant than HCT116 cells. According to our results, Mhaidat and colleagues also demonstrated that HCT-116 cells, in a panel of cancer cell lines, were the most sensitivity to 5-Fu (Mhaidat et al., 2014). Lower sensitivity of HT-29 cells may be due to its genetic characteristics. HT-29 cancer cell line derived from a human adenocarcinoma, is aneuploid, presents chromosomal instability and is p53 mutant (Ahmed et al., 2013). Whereas, HCT-116 a cancer cell line derived from a human carcinoma, is near to diploid colon cancer cell line, does not present chromosomal instability and is $p 53^{w / t}$ (Thompson \& Compton, 2010). Therefore, some studies imply the existence of a link between chromosomal instability, aneuploidy and loss of p53 function with an intrinsic multidrug resistance, namely decreased sensitivity to 5-Fu (Swanton et al., 2006; Lee et al., 2011).

The marine carotenoid, fucoxanthin, exhibited dose-dependent cytotoxic effects against the two cancer cell lines tested. At 50 and $100 \mu \mathrm{M}$ fucoxanthin a greater cytotoxic effect was observed when compared to similar doses of 5-Fu. Taking into account that $5-\mathrm{Fu}$ is one of the most widely used drugs in the treatment of colorectal cancer, the cytotoxic effect of fucoxanthin is quite promising. The cytotoxic effect of 
fucoxanthin is accomplished with an increase of DNA damage induction in both cells lines. In most of the cases increasing DNA damage, such as strand breaks formation without proper repair, promotes an apoptotic event which is the result of complex enzymatic reactions (e.g. activation of pro-apoptotic factors such as Bax and caspases) (Ros \& Kaina, 2006). In HCT-116 cells, fucoxanthin increased p53 expression with a decrease of $\mathrm{Bcl}-2$, while in HT-29 cells an increase of Bax and a decrease of procaspase 9 was observed. The prooxidant activity of fucoxanthin has been previously reported in several cell models (Kumar et al, 2013). In HL-60 cells (human promyelocytic leukemia cell line) the levels of reactive oxygen species (ROS) increased after exposure to fucoxanthin with induction of apoptosis through ROS-mediated $\mathrm{Bcl}-\mathrm{xL}$ pathway (Kim et al. 2010). Although the effect of fucoxanthin on cell viability has previously been reported in several human colon cell lines (e.g. HCT-116 cells Caco-2, DLD-1 and HT-29) molecular mechanisms remain unclear (Hosokawa et al., 2004; Kotake-Nara et al., 2005).

The effect of fucoxanthin combined with $5-\mathrm{Fu}$ in HCT-116 and HT-29 cells is reported here for the first time. Fucoxanthin significantly increased 5-Fu induced cytotoxicity in both cancer cell lines at smaller doses. In HCT-116 cells, fucoxanthin coincubated with 5-Fu increased protein levels of p53 and p27 when compared with 5-Fu treatment suggesting a cell cycle arrest. Besides the increase of $\mathrm{Bax} / \mathrm{Bcl}-2$ ratio and procaspase 9 induced by fucoxanthin plus $5-\mathrm{Fu}$, no increase of nuclear condensation was observed relative to 5-Fu alone. In HT-29 cells fucoxanthin enhanced 5-Fu cytotoxicity by induction of apoptosis with increase of Bax expression and cell cycle arrest mediated by up-regulation of p27 protein expression. This promoter activity by fucoxanthin was assessed by a previous study, which demonstrated that fucoxanthin synergistically enhanced the cytotoxicity of some chemotherapeutic drugs, such 5-Fu, vinblastine and etoposide, in Caco-2 cells by inhibition of $A B C$ transporters (Eid et al., 2012). Notwithstanding, in our study it seems that the enhancement of 5-Fu cytotoxicity by fucoxanthin is mediated by cell cycle arrest and activation of apoptosis in colon cancer cells but not in normal cells.

Phloroglucinol, at higher concentration, decreased cell viability in both cell lines tested with increase of nuclear condensation and without induction of DNA damage detected by comet assay. A similar decrease in cell viability and induction of apoptosis in HT-29 cells has been reported for phloroglucinol (Kang et al., 2014). In co-incubation phloroglucinol increased the sensitivity to $5-\mathrm{Fu}$ in both cancer cell lines. An identical effect was reported by Pinhatti and colleagues, demonstrating that the association of japonicin A (a dimeric phloroglucinol) with paclitaxel had a synergistic effect resulting in a decrease of cellular proliferation of the OVCAR-3 cell line (Pinhatti et al., 2013). In 
the present study, we show for the first time the effect of phloroglucinol in combination with 5-Fu in HCT-116 and HT-29 cells. However this combination was more efficient in HT-29 cells with an increase of Bax and p27 protein expression suggesting induction of apoptosis and cell cycle arrest as possible anticancer mechanisms. As this effect was observed in a cell line with some 5-Fu resistance, combination of phloroglucinol with 5Fu could be promising in resistance cells mainly with p53 mutant.

The antioxidant activity of phloroglucinol has been reported in several cell models (Kang et al., 2006; Kang et al., 2010; So \& Cho, 2014). In our study, phloroglucinol at lower concentrations in co-incubation with 5-Fu showed a significant increased viability in HCT-116 cells. The protective effect was accomplish with an increase of p53, Bcl-2 and procaspase 9 expression relative to cells treated with $5-\mathrm{Fu}$. These results are in agreement with a study conducted by Fu and colleagues showing a decrease in apoptosis when 5-Fu, responsible for inducing ROS formation, is combined with antioxidants in colon cancer cells (Fu et al., 2014). However, the protective effect of phloroglucinol was only observed when in co-incubation with 5-Fu and in lower concentrations of phloroglucinol, other regimes do not seem to have the same protective effect. In fact, higher concentrations of phloroglucinol in combination with $5-\mathrm{Fu}$ results in a decrease of cell viability in HCT-116 cells suggesting that phloroglucinol can also behave like a prooxidant under certain conditions, such as high concentrations or in the presence of oxygen molecules (Bouayed \& Bohn, 2010; Cotoras et al., 2014).

Besides the cytotoxicity of fucoxanthin and phloroglucinol in cancer cells, our data showed that no toxicity was observed in normal cells, except for higher concentrations of fucoxanthin. According with our results, some studies reported that normal cells when exposed to fucoxanthin and phloroglucinol were unaffected or were less affected than hepatoma or colon cancer cells demonstrating the selective effect of the two compounds (Kotake-Nara et al., 2005; Liu et al., 2009; Kang et al., 2014).

In conclusion, the results of this study indicate that fucoxanthin decreased cell viability more efficiently than $5-\mathrm{Fu}$ alone and when in co-incubation enhance the cytotoxic effect of 5-Fu, without toxicity to normal cells, which could be a promising alternative for resistant colorectal cancer cell lines. Phloroglucinol alone also decreased cell viability and in combination increased the sensitivity to 5 -Fu in both cancer cell lines, especially in p53 mutant HT-29 cancer cell line. Nonetheless, at lower concentrations phloroglucinol inhibited the effects of 5-Fu in HCT-116 cells, which is not desired during cancer treatment. Induction of DNA damage (only in fucoxanthin), cell cycle arrest and apoptosis seem to be involved in the anticancer effects of fucoxanthin and phloroglucinol in colon cancer cells. However, the exact mechanisms 
involved needs to be further explored. Our results suggest that both natural compounds could be in the future a possible alternative to enhance the efficiency of $5-\mathrm{Fu}$ in resistant colon cancer cells. This study supports the potential of seaweeds as source of bioactive compounds with biomedical applications. 


\section{REFERENCES}

Ahmed, D., Eide, P. W., Eilertsen, I. A, Danielsen, S. A, Eknæs, M., Hektoen, M., Lind, G. E., Lothe, R. A. (2013). Epigenetic and genetic features of 24 colon cancer cell lines. Oncogenesis, 2(9), e71.

Bracht, K., Nicholls, a M., Liu, Y., \& Bodmer, W. F. (2010). 5-Fluorouracil response in a large panel of colorectal cancer cell lines is associated with mismatch repair deficiency. British Journal of Cancer, 103(3), 340-346.

Bouayed, J., \& Bohn, T. (2010). Exogenous Antioxidants-Double-Edged Swords in Cellular Redox State: Health Beneficial Effects at Physiologic Doses versus Deleterious Effects at High Doses. Oxidative Medicine and Cellular Longevity, 3(4), 228-237.

Burtin, P. (2003). Nutritional Value of Seaweeds. Electronic Journal of Environmental, Agricultural and Food Chemistry, 2(4), 1579 - 4377.

Cotoras, M., Vivanco, H., Melo, R., Aguirre, M., Silva, E., \& Mendoza, L. (2014). In Vitro and in Vivo Evaluation of the Antioxidant and Prooxidant Activity of Phenolic Compounds Obtained from Grape (Vitis vinifera) Pomace. Molecules, 19(12), 2115421167.

Eid, S. Y., El-Readi, M. Z., \& Wink, M. (2012). Carotenoids reverse multidrug resistance in cancer cells by interfering with ABC-transporters. Phytomedicine, 19(11), 977-987.

Elmore, S. (2007). Apoptosis: A review of Programmed Cell Death. Toxicol Pathol, 29(6), 997-1003.

Focaccetti, C., Bruno, A., Magnani, E., Bartolini, D., Principi, E., Dallaglio, K., Bucci, E. O., Finzi, G., Sessa, F., Noonan, D. M., Albini, A. (2015). Effects of 5-Fluorouracil on Morphology, Cell Cycle, Proliferation, Apoptosis, Autophagy and ROS Production in Endothelial Cells and Cardiomyocytes. Plos One, 10(2), e0115686.

Fu, Y., Yang, G., Zhu, F., Peng, C., Li, W., Li, H., Kim, H-G., Bode, A. M., Dong, Z., Dong, Z. (2014). Antioxidants decrease the apoptotic effect of 5-Fu in colon cancer by regulating Src-dependent caspase-7 phosphorylation. Cell Death \& Disease, 5, e983.

Globocan 2012 : Estimated Cancer Incidence, Mortalitty and Prevalence Worldwide in 2012 Retrieved June 21, 2015, from http://globocan.iarc.fr/Pages/ fact_sheets_cancer. aspx

Grem, J. (2000). 5-Fluorouracil: Forty-plus and still ticking. A review of its preclinical and clinical development. Investigational New Drugs, 18(4), 299-313.

Haggar, F. a, Boushey, R. P., \& Ph, D. (2009). Colorectal Cancer Epidemiology: Incidence, Mortality , Survival, and Risk Factors. Clinics in Colon and Rectal Surgery, 6(212), 191-197. 
Hanahan, D., \& Weinberg, R. A. (2011). Hallmarks of cancer: the next generation. Cell, 144(5), 646-74.

Hosokawa, M., Kudo, M., Maeda, H., Kohno, H., Tanaka, T., \& Miyashita, K. (2004). Fucoxanthin induces apoptosis and enhances the antiproliferative effect of the PPARY ligand, troglitazone, on colon cancer cells. Biochimica et Biophysica Acta (BBA) General Subjects, 1675(1-3), 113-119.

Ji, H.-F., Li, X.-J., \& Zhang, H.-Y. (2009). Natural products and drug discovery. Can thousands of years of ancient medical knowledge lead us to new and powerful drug combinations in the fight against cancer and dementia? EMBO Reports, 10(3), 194200.

Jin, D.-Q., Lim, C. S., Sung, J.-Y., Choi, H. G., Ha, I., \& Han, J.-S. (2006). Ulva conglobata, a marine algae, has neuroprotective and anti-inflammatory effects in murine hippocampal and microglial cells. Neuroscience Letters, 402(1-2), 154-158.

Kang, M.-H., Kim, I.-H., \& Nam, T.-J. (2014b). Phloroglucinol induces apoptosis via apoptotic signaling pathways in HT-29 colon cancer cells. Oncology Reports, 13411346.

Kang, K. A., Zhang, R., Chae, S., Lee, S. J., Kim, J., Kim, J., Jeong, J., Lee, J., Shin, T., Lee, N. H., Hyun, J. W. (2010). Phloroglucinol (1,3,5-trihydroxybenzene) protects against ionizing radiation-induced cell damage through inhibition of oxidative stress in vitro and in vivo. Chemico-Biological Interactions, 185(3), 215-226.

Kang, K. a., Lee, K. H., Chae, S., Zhang, R., Jung, M. S., Ham, Y. M., Baik, J. S., Lee, N. H., Hyun, J. W. (2006). Cytoprotective effect of phloroglucinol on oxidative stress induced cell damage via catalase activation. Journal of Cellular Biochemistry, 97(3), 609-620.

Kim, K.-N., Heo, S.-J., Kang, S.-M., Ahn, G., \& Jeon, Y.-J. (2010). Fucoxanthin induces apoptosis in human leukemia HL-60 cells through a ROS-mediated Bcl-xL pathway. Toxicology in Vitro, 24(6), 1648-1654.

Kong, C. S., Kim, J. A., Yoon, N. Y., \& Kim, S. K. (2009). Induction of apoptosis by phloroglucinol derivative from Ecklonia cava in MCF-7 human breast cancer cells. Food and Chemical Toxicology, 47(7), 1653-1658.

Kotake-Nara, E., Sugawara, T., \& Nagao, A. (2005). Antiproliferative effect of neoxanthin and fucoxanthin on cultured cells. Fisheries Science, 71(2), 459-461.

Kumar, S. R., Hosokawa, M., \& Miyashita, K. (2013). Fucoxanthin: A marine carotenoid exerting anti-cancer effects by affecting multiple mechanisms. Marine Drugs, 11(12), 5130-5147.

Lee, A. J. X., Endesfelder, D., Rowan, A. J., Walther, A., Birkbak, N. J., Futreal, P. A., Downward, J., Szallasi, Z., Tomlinson, I. P. M., Howell, M., Kschischo, M., Swanton, C. (2011). Chromosomal instability confers intrinsic multidrug resistance. Cancer Research, 71(5), 1858-1870.

Lee, J.-C., Hou, M.-F., Huang, H.-W., Chang, F.-R., Yeh, C.-C., Tang, J.-Y., \& Chang, H.-W. (2013). Marine algal natural products with anti-oxidative, anti-inflammatory, and anti-cancer properties. Cancer Cell International, 13(1), 55. 
Lee, S.-H., \& Jeon, Y.-J. (2013). Anti-diabetic effects of brown algae derived phlorotannins, marine polyphenols through diverse mechanisms. Fitoterapia, 86, 129136.

Li, J., Hou, N., Faried, A., Tsutsumi, S., Takeuchi, T., \& Kuwano, H. (2009). Inhibition of autophagy by 3-ma enhances the effect of 5 -fu-induced apoptosis in colon cancer cells. Annals of Surgical Oncology, 16(3), 761-771.

Liu, C.-L., Huang, Y.-S., Hosokawa, M., Miyashita, K., \& Hu, M.-L. (2009). Inhibition of proliferation of a hepatoma cell line by fucoxanthin in relation to cell cycle arrest and enhanced gap junctional intercellular communication. Chemico-Biological Interactions, 182(2-3), 165-172.

Maeda, H., Hosokawa, M., Sashima, T., Funayama, K., \& Miyashita, K. (2005). Fucoxanthin from edible seaweed, Undaria pinnatifida, shows antiobesity effect through UCP1 expression in white adipose tissues. Biochemical and Biophysical Research Communications, 332(2), 392-7.

Mhaidat, N. M., Bouklihacene, M., \& Thorne, R. F. (2014). 5-Fluorouracil-induced apoptosis in colorectal cancer cells is caspase-9-dependent and mediated by activation of protein kinase C- $\delta$. Oncology Letters, 8(2), 699-704.

McHugh, D. J. (2003). A guide to the seaweed industry. FAO Fisheries Technical Paper, 441.

McKnight, J. A. (2003). Principles of Chemotherapy. Clinical Techniques in Smal Animal Practice, 18, 21-37.

Nakashima, Y., Ohsawa, I., Konishi, F., Hasegawa, T., Kumamoto, S., Suzuki, Y., \& Ohta, S. (2009). Preventive effects of Chlorella on cognitive decline in age-dependent dementia model mice. Neuroscience Letters, 464(3), 193-8.

Nita, M. E., Nagawa, H., Tominaga, O., Tsuno, N., Fujii, S., Sasaki, Fu, C.G., Takenoue, T., Muto, T. (1998). 5-Fluorouracil induces apoptosis in human colon cancer cell lines with modulation of Bcl-2 family proteins. British Journal of Cancer, 78(8), 986992.

Peng, J., Yuan, J. P., Wu, C. F., \& Wang, J. H. (2011). Fucoxanthin, a marine carotenoid present in brown seaweeds and diatoms: Metabolism and bioactivities relevant to human health. Marine Drugs, 9(10), 1806-1828.

Pinhatti, A. V, de Barros, F. M. C., de Farias, C. B., Schwartsmann, G., Poser, G. L. Von, \& Abujamra, A. L. (2013). Antiproliferative activity of the dimeric phloroglucinol and benzophenone derivatives of Hypericum spp. native to southern Brazil. AntiCancer Drugs, 24(7), 699-703.

Raja, A., Vipin, C., \& Aiyappan, A. (2013). Review Article Biological importance of Marine Algae- An overview. International Journal of Current Microbiology and Applied Sciences, 2(5), 222-227.

Ramos, A. A., Pereira-Wilson, C., \& Collins, A. R. (2010). Protective effects of Ursolic acid and Luteolin against oxidative DNA damage include enhancement of DNA repair in Caco-2 cells. Mutation Research/Fundamental and Molecular Mechanisms of Mutagenesis, 692(1-2), 6-11. 
Swanton, C., Tomlinson, I., \& Downward, J. (2006). Chromosomal Instability, Colorectal Cancer and Taxane Resistance. Cell Cycle, 5(8), 818-823

Singh, I. P., Sidana, J., Bansal, P., \& Foley, W. J. (2009). Phloroglucinol compounds of therapeutic interest: global patent and technology status. Expert Opinion on Therapeutic Patents, 19(6), 847-866.

So, M. J., \& Cho, E. J. (2014). Phloroglucinol Attenuates Free Radical-induced Oxidative Stress. Preventive Nutrition And Food Science., 19(3), 129-135.

Taylor, R. C., Cullen, S. P., \& Martin, S. J. (2008). Apoptosis: controlled demolition at the cellular level. Nature Reviews. Molecular Cell Biology, 9(3), 231-241.

Thompson, S. L., \& Compton, D. a. (2010). Proliferation of aneuploid human cells is limited by a p53-dependent mechanism. The Journal of Cell Biology, 188(3), 369-381.

Vigani, M., Parisi, C., Rodríguez-Cerezo, E., Barbosa, M. J., Sijtsma, L., Ploeg, M., \& Enzing, C. (2015). Food and feed products from micro-algae: Market opportunities and challenges for the EU. Trends in Food Science \& Technology, 42(1), 81-92.

Yu, R. X., Hu, X. M., Xu, S. Q., Jiang, Z. J., \& Yang, W. (2011). Effects of fucoxanthin on proliferation and apoptosis in human gastric adenocarcinoma MGC-803 cells via JAK/STAT signal pathway. European Journal of Pharmacology, 657(1-3), 10-19.

Zhang, N., Yin, Y., Xu, S. J., \& Chen, W. S. (2008). 5-Fluorouracil: Mechanisms of resistance and reversal strategies. Molecules, 13(8), 1551-1569.

Zhang, Z., Zhang, P., Hamada, M., Takahashi, S., Xing, G., Liu, J., \& Sugiura, N. (2008). Potential chemoprevention effect of dietary fucoxanthin on urinary bladder cancer EJ-1 cell line. Oncology Reports, 20, 1099-1103.

Zorofchian Moghadamtousi, S., Karimian, H., Khanabdali, R., Razavi, M., Firoozinia, M., Zandi, K., \& Abdul Kadir, H. (2014). Anticancer and antitumor potential of fucoidan and fucoxanthin, two main metabolites isolated from brown algae. The Scientific World Journal, 2014. 
CHAPTER III - CONCLUSIONS AND FUTURE PERSPECTIVES 


\section{CONCLUSIONS AND FUTURE PERSPECTIVES}

The aim of this study was to assess the in vitro anticancer bioactivity of two algae compounds, fucoxanthin and phloroglucinol, alone and in co-incubation with 5-Fu on two colorectal cancer cell lines (HCT-116 and HT-29). Also, to assess the specificity of the anticancer effects, a normal colon cell line (CCD-Co18) was tested.

Results demonstrated that 5-Fu decreased cell viability in a dose-dependent manner with ability to induce DNA damage in both cell lines, with HCT-116 cells revealing increased sensitivity to 5-Fu. Furthermore, fucoxanthin decreased cell viability more efficiently than $5-\mathrm{Fu}$ alone and when in co-incubation enhanced the cytotoxic effect of 5-Fu, without toxicity to normal cells, which could be a promising alternative for resistant colorectal cancer cell lines. Phloroglucinol alone also decreased cell viability and in combination increased the sensitivity to 5 -Fu in both cancer cell lines, especially in p53 mutant the HT-29 cancer cell line. Nonetheless, at lower concentrations phloroglucinol inhibited the effects of $5-\mathrm{Fu}$ in HCT-116 cells, a non-desired side effect.

Considering these results, fucoxanthin and phloroglucinol seem to be very promising agents in the potentiation of anticancer drugs, namely $5-\mathrm{Fu}$, in resistant colon cancer cells. Induction of DNA damage (in fucoxanthin), cell cycle arrest and apoptosis seems to be involved in the anticancer effects of fucoxanthin and phloroglucinol in colon cancer cells. However, the exact mechanisms involved need to be further explored with the addition of other assays that can provide supplementary information such as assessment of mitochondrial membrane potential, cytochrome $c$ release, DNA fragmentation analysis, cell cycle arrest (by flow cytometry), determination of reactive oxygen species (ROS) generation, as well as molecular targets and signaling pathways involved.

Attending to the antioxidant and prooxidant activities displayed by phloroglucinol in HCT-116 cancer cell line, when co-incubated with 5-Fu it is important to clarify in which conditions these two opposite effects occur. The test of a higher number of cancer cells and normal cells should be also of utmost importance in the validation of these compounds as potential anticancer drugs.

Screening for natural compounds with anticancer activity that could work alone or in combination with other chemotherapeutic drugs is now one of the main focus in investigation, in order to increase the therapeutic efficacy and minimize toxicity on 
healthy cells. In this study, we reported for the first time the ability of fucoxanthin and phloroglucinol to enhance the cytotoxic effect of 5-Fu in HCT-116 and HT-29 cancer cell lines without toxicity in normal colon cell line. These new data can contribute to stimulate the interest at looking to seaweed farming and biotechnological use with growing interest. 
CHAPTER IV - APPENDIX - PROTOCOLS 


\section{APPENDIX - PROTOCOLS}

\section{MTT Cell Proliferation Assay}

Work solutions preparation

A. 1x PBS buffer

To obtain 1L of PBS buffer solution:

- weigh all reagents necessary, according to the table below.

- dissolve in $800 \mathrm{ml}$ of ultrapure $\mathrm{H}_{2} \mathrm{O}$;

- $\quad$ adjust $\mathrm{pH}$ to 7.4 ;

- add ultrapure $\mathrm{H}_{2} \mathrm{O}$ to a final volume of $1 \mathrm{~L}$.

PBS buffer solution should be sterilized (autoclave) and then store at $4^{\circ} \mathrm{C}$.

\begin{tabular}{|r|r|c|}
\hline & Final concentration & Weight \\
\hline $\mathrm{NaCl}$ & $137.0 \mathrm{mM}$ & $8.0 \mathrm{~g}$ \\
\hline $\mathrm{Kcl}$ & $2.7 \mathrm{mM}$ & $0.20 \mathrm{~g}$ \\
\hline $\mathrm{Na}_{2} \mathrm{PO}_{4}$ & $10.0 \mathrm{mM}$ & $1.44 \mathrm{~g}$ \\
\hline $\mathrm{KH}_{2} \mathrm{PO}_{4}$ & $2.0 \mathrm{mM}$ & $0.24 \mathrm{~g}$ \\
\hline
\end{tabular}

B. MTT sock solution $(5 \mathrm{mg} / \mathrm{ml})$

For a final concentration of $5 \mathrm{mg} / \mathrm{ml}$ of MTT, dissolve $50 \mathrm{mg}$ of MTT in $10 \mathrm{ml}$ of PBS. Store at $-20^{\circ} \mathrm{C}$.

* MTT is highly toxic and carcinogenic. Do not mix with normal waste. 
C. Organic solvent solution - DMSO:Ethanol (1:1)

To obtain a final volume of $500 \mathrm{ml}$, add $250 \mathrm{ml}$ of DMSO and $250 \mathrm{ml}$ of absolute ethanol. This solution should be store protected from the light at room temperature.

${ }^{*}$ DMSO is toxic and highly volatile. Attention to toxic vapors.

\section{Procedure}

(All work should be performed under aseptic conditions using a laminar flow hood.) (Incubation at $37^{\circ} \mathrm{C}$ with $5 \%$ of $\mathrm{CO}_{2}$ )

1. Plate cells in a 96-multiwell culture plate with a final volume of $100 \mu \mathrm{l} /$ well respecting the appropriate cellular density for each cell line. Cells should be incubated for $24 \mathrm{~h}$ to promote cell adhesion.

2. Incubate the cells with the respective treatment and at this moment apply 10 $\mu \mathrm{l}$ of MTT $(0.5 \mu \mathrm{g} / \mathrm{ml})$ to the initial control (Ci).

3. After $2 \mathrm{~h}$ of incubation, remove the medium from the Ci. This step should be done carefully without removing the formazan crystals which are adhere to the bottom of the well.

4. Leave the treated cells incubate for the rest of the experimental time.

5. When completed the time of exposure apply $10 \mu \mathrm{l}$ of MTT $(0.5 \mu \mathrm{l} / \mathrm{mg})$ per well.

6. After $2 \mathrm{~h}$ of incubation, remove the medium and add $150 \mu \mathrm{l}$ of the organic solvent solution (DMSO:Ethanol) in all wells.

7. From this point forward protect the plate from light. Formazan crystals are photosensitivity.

8. Gently, shake the plate until a homogenous solution is obtained (normally, for $10 \mathrm{~min}$.)

9. In a microplate reader, using a wavelength of $570 \mathrm{~nm}$, register the optical density of the samples.

10. The percentage of cell viability is calculated using the follow equation:

$$
\% \text { of cell viability }=\left(O \mathrm{~d}_{\text {sample }} \mathrm{X} 100\right) /\left(O D_{\mathrm{Cf}}\right)
$$




\section{Nuclear Condensation Assay}

Work solutions preparation

A. 1x PBS buffer

To obtain $1 \mathrm{~L}$ of PBS buffer solution:

- weigh all reagents necessary, according to the table below.

- dissolve in $800 \mathrm{ml}$ of ultrapure $\mathrm{H}_{2} \mathrm{O}$;

- $\quad$ adjust $\mathrm{pH}$ to 7.4 ;

- add ultrapure $\mathrm{H}_{2} \mathrm{O}$ to a final volume of $1 \mathrm{~L}$.

PBS buffer solution should be sterilized (autoclave) and then store at $4^{\circ} \mathrm{C}$.

\begin{tabular}{|r|r|c|}
\hline & Final concentration & Weight \\
\hline $\mathrm{NaCl}$ & $137.0 \mathrm{mM}$ & $8.0 \mathrm{~g}$ \\
\hline $\mathrm{Kcl}$ & $2.7 \mathrm{mM}$ & $0.20 \mathrm{~g}$ \\
\hline $\mathrm{Na}_{2} \mathrm{PO}_{4}$ & $10.0 \mathrm{mM}$ & $1.44 \mathrm{~g}$ \\
\hline $\mathrm{KH}_{2} \mathrm{PO}_{4}$ & $2.0 \mathrm{mM}$ & $0.24 \mathrm{~g}$ \\
\hline
\end{tabular}

B. DAPI staining solution $(1 \mu \mathrm{g} / \mathrm{ml})$

Prepare a $1 \mu \mathrm{g} / \mathrm{ml}$ working solution in ultrapure $\mathrm{H}_{2} \mathrm{O}$ (DAPI stock solution 100 $\mu \mathrm{g} / \mathrm{ml})$. Store at $-20^{\circ} \mathrm{C}$, protected from light.

* DAPI is carcinogenic.

C. $50 \%$ Glycerol solution (v/v)

To obtain $10 \mathrm{ml}$ of glycerol solution, mix $5 \mathrm{ml}$ of glycerol on $5 \mathrm{ml}$ of PBS (1x)

D. $4 \%$ Paraformaldehyde (PFA) (w/v)

To prepare $100 \mathrm{ml}$, weight $4 \mathrm{~g}$ of PFA and add PBS (1x) at make $100 \mathrm{ml}$. To dissolve the solution, place it in a harm water bath $\left(60^{\circ} \mathrm{C}\right)$ and stir frequently. 
When dissolved, allow the solution to cool at room temperature and adjust the $\mathrm{pH}$ to 7.4 . Store at $-20^{\circ} \mathrm{C}$ until use.

\section{Procedure \\ (Incubation at $37^{\circ} \mathrm{C}$ with $5 \%$ of $\mathrm{CO}_{2}$ )}

\section{Sample preparation}

1. Plate cells in a 12-multiwell culture plate with a final volume of $1 \mathrm{ml} / \mathrm{well}$, respecting the appropriate cellular density for each cell line. Cells should be incubated for $24 \mathrm{~h}$ to promote cell adhesion.

2. Incubate the cells with the respective treatment.

3. When completed the incubation time, collect the medium from each well into a respectively labeled tube.

4. Wash with $1 \mathrm{ml}$ of PBS (1x) each well and collect to the respective centrifuge tube.

5. Add $150 \mu \mathrm{l}$ of warm trypsin/EDTA solution and leave $5 \mathrm{~min}$ in the incubator.

6. Add $400 \mu \mathrm{l}$ of medium in each well to stop the trypsinization process. Carefully, resuspend the cells and collect to the respective tube.

7. Wash with $1 \mathrm{ml}$ of PBS (1x) each well and collect again to the respective centrifuge tube.

8. Centrifuge the tubes for $5 \mathrm{~min}$ at $2000 \mathrm{rpm}$.

9. Collect $500 \mu \mathrm{l}$ of the supernatant and discard the remaing without disrupting the pellet.

10. To the $500 \mu \mathrm{l}$ add $3 \mathrm{ml}$ of PBS (1x) and gently resuspend.

11. Centrifuge the tubes for $5 \mathrm{~min}$ at $2000 \mathrm{rpm}$.

12. Discard the supernatant until $500 \mu \mathrm{l}$ and resuspend the pellet.

13. Add $2 \mathrm{ml}$ of PFA at $4 \%$ and incubate for at least $20 \mathrm{~min}$ at $37^{\circ} \mathrm{C}$.

14. Add $4 \mathrm{ml}$ of PBS (1x) to each tube and centrifuge for $5 \mathrm{~min}$ at $2000 \mathrm{rpm}$.

15. Discard the supernatant until $500 \mu \mathrm{l}$ and resuspend the pellet.

16. Transfer each samples into tubes of $1.5 \mathrm{ml}$ properly identified.

17. If desired, store the samples at $4^{\circ} \mathrm{C}$.

* Samples will remain stable for several months. 


\section{Nuclear staining}

1. Mount the poly $-\mathrm{L}-$ Lysine slides into the appropriate cytocentrifuge frames.

2. Pipette around $80-120 \mu \mathrm{l}$ of each resuspend sample into a cytocentrifuge tube.

3. Centrifuge the slides for $5 \mathrm{~min}$ at $500 \mathrm{rpm}$.

4. Carefully, unmount the slides and verify that the cells are adhered to the slide.

5. With a hydrophobic pen circle the adherent cells, and leave to air dry for around $20 \mathrm{~min}$.

6. Wash the slides 3 times with PBS (1x), each wash should be for $5 \mathrm{~min}$.

7. Incubate with DAPI $(1 \mu \mathrm{g} / \mathrm{ml})$ for 10 min protected from the light.

8. Add $6 \mu \mathrm{l}$ of glycerol at $50 \%$ to each sample, and place a coverslip.

9. Observe the samples by using a fluorescence microscope or store at $-20^{\circ} \mathrm{C}$ in the dark.

\section{Quantification}

Quantification of nuclear condensation is obtained by counting at least 300 cells with condensed nuclei. The percentage of nuclear condensation is obtained by applying the following equation:

$\%$ of cells with condensed nuclei $=$ (number of cells with condensed nuclei $/$ total number of cells counted) $\times 100$ 


\section{Comet Assay}

Work solutions preparation

A. 1x PBS buffer

To obtain 1L of PBS buffer solution:

- weigh all reagents necessary, according to the table below.

- dissolve in $800 \mathrm{ml}$ of ultrapure $\mathrm{H}_{2} \mathrm{O}$;

- $\quad$ adjust $\mathrm{pH}$ to 7.4 ;

- add ultrapure $\mathrm{H}_{2} \mathrm{O}$ to a final volume of $1 \mathrm{~L}$.

PBS buffer solution should be sterilized (autoclave) and then store at $4^{\circ} \mathrm{C}$.

\begin{tabular}{|r|r|c|}
\hline & Final concentration & Weight \\
\hline $\mathrm{NaCl}$ & $137.0 \mathrm{mM}$ & $8.0 \mathrm{~g}$ \\
\hline $\mathrm{Kcl}$ & $2.7 \mathrm{mM}$ & $0.20 \mathrm{~g}$ \\
\hline $\mathrm{Na}_{2} \mathrm{PO}_{4}$ & $10.0 \mathrm{mM}$ & $1.44 \mathrm{~g}$ \\
\hline $\mathrm{KH}_{2} \mathrm{PO}_{4}$ & $2.0 \mathrm{mM}$ & $0.24 \mathrm{~g}$ \\
\hline
\end{tabular}

B. $1 \%$ Normal Melting Point Agarose (NMP) (w/v)

Mix $200 \mathrm{mg}$ of normal melting point agarose (NMP) with distilled water until 20 $\mathrm{ml}$. To dissolve the solution, heat in a microwave for 1 to $2 \mathrm{~min}$ at full power. The solution should be stored at $4^{\circ} \mathrm{C}$. Before use, melt the solution.

C. $0.5 \%$ Low Melting Point Agarose (LMP) (w/v)

Mix $100 \mathrm{~g}$ of low melting point agarose (LMP) with PBS (1x) until $20 \mathrm{ml}$. To dissolve the solution, heat in a microwave for 1 to $2 \mathrm{~min}$ at full power. The solution should be stored at $4^{\circ} \mathrm{C}$. Before use, melt the solution. 
D. Lysis solution, $\mathrm{pH} 10$

To obtain $1 \mathrm{~L}$ of lysis solution add $\mathrm{NaCl}, \mathrm{Na}_{2}$ EDTA and Tris Base with the respective weight and add around $5 \mathrm{~g}$ of $\mathrm{NaOH}$ (save $\sim 2 \mathrm{~g}$ ). Add distilled water until $900 \mathrm{ml}$ and stir. The remaining $2 \mathrm{~g}$ of $\mathrm{NaOH}$ will be gradually added to the solution as the dissolution occurs and until reaching the correct $\mathrm{pH}$. When totally dissolved add the remaining distilled water until $1 \mathrm{~L}$. Store the solution at $4^{\circ} \mathrm{C}$. Triton $\mathrm{X}-1001 \%(\mathrm{v} / \mathrm{v})$ is added immediately prior to use.

\begin{tabular}{|c|c|c|}
\hline & Final concentration & Weight \\
\hline $\mathrm{NaCl}$ & $2.5 \mathrm{M}$ & $146.1 \mathrm{~g}$ \\
\hline $\mathrm{Na}_{2} \mathrm{EDTA}$ & $100.0 \mathrm{mM}$ & $37.2 \mathrm{~g}$ \\
\hline Tris Base & $10.0 \mathrm{mM}$ & $1.21 \mathrm{~g}$ \\
\hline $\mathrm{NaOH}$ to $\mathrm{pH}$ of 10 & & Approx. $7 \mathrm{~g}$ \\
\hline
\end{tabular}

E. Electrophoresis Buffer (300 mM NaOH, 1 mM Na${ }_{2}$ EDTA, pH13)

Weigh $120 \mathrm{~g}$ of $\mathrm{NaOH}$ (final concentration of $3 \mathrm{M}$ ) add distilled water to $1 \mathrm{~L}$. Dissolve and store at $4^{\circ} \mathrm{C}$.

Weigh $3.722 \mathrm{~g}$ of $\mathrm{Na}_{2}$ EDTA (final concentration of $200 \mathrm{mM}$ ) add distilled water to $50 \mathrm{ml}$. Dissolve and store $4^{\circ} \mathrm{C}$.

The solutions should only be mix when they were accurate. For $1 \mathrm{~L}$ of electrophoresis buffer mix $100 \mathrm{ml}$ of $\mathrm{NaOH}(3 \mathrm{M}), 5 \mathrm{ml}$ of $\mathrm{Na}_{2}$ EDTA (200 mM) and $895 \mathrm{ml}$ of distilled water.

F. DAPI staining solution $(1 \mu \mathrm{g} / \mathrm{ml})$

Prepare a $1 \mu \mathrm{g} / \mathrm{ml}$ working solution in ultrapure $\mathrm{H}_{2} \mathrm{O}$ (DAPI stock solution 100 $\mu \mathrm{g} / \mathrm{ml}$ ). Store at $-20^{\circ} \mathrm{C}$, protected from light.

* DAPI is carcinogenic. 


\section{Procedure}

(Incubation at $37^{\circ} \mathrm{C}$ with $5 \%$ of $\mathrm{CO}_{2}$ )

1. Plate cells in a 24-multiwell culture plate with a final volume of $1 \mathrm{ml} / \mathrm{well}$, respecting the appropriate cellular density for each cell line. Cells should be incubated for $24 \mathrm{~h}$ to promote cell adhesion.

2. Incubate the cells with the respective treatment.

3. When completed the incubation time, discard the medium from each well and wash twice with $200 \mu$ l of PBS (1x).

4. Add $100 \mu \mathrm{l}$ of trypsin/EDTA solution and incubate for about $5 \mathrm{~min}$.

5. Add $200 \mu \mathrm{l}$ of medium to stop the action of the trypsin and resuspend.

6. Prepare a cell suspension $\left(5 \times 10^{4}\right.$ cells $\left./ \mathrm{ml}\right)$ into a microtube.

7. From this point forward the cells must be kept on ice.

8. Centrifuge cells for $1 \mathrm{~min}$ at $5000 \mathrm{rpm}$.

9. Discard supernatant, and gently resuspend cells in $100 \mu \mathrm{l}$ of LMP previously melted.

10. Apply $\sim 75 \mu \mathrm{l}$ of the LMP agarose/cell suspension on the slide and place a coverslip. Keep the slides at $4^{\circ} \mathrm{C}$ for $10 \mathrm{~min}$.

11. When the LMP agarose in the slides is solidified, gently remove the coverslips.

12. Prepare the working lysis solution, add $100 \mathrm{ml}$ of lysis solution with $1 \mathrm{ml}$ of Triton X- $1001 \%(\mathrm{v} / \mathrm{v})$, and fully immerse the slides.

13. Incubate for $2 \mathrm{~h}$ at $4^{\circ} \mathrm{C}$ in the dark.

14. Prepare the electrophoresis buffer, and pour into the electrophoresis tank at $4^{\circ} \mathrm{C}$.

15. Before placing the slides in the electrophoresis thank rinse the slides with distilled water.

16. Incubate the slides in the alkaline electrophoresis buffer for $40 \mathrm{~min}$ at $4^{\circ} \mathrm{C}$ to allow the DNA to unwind.

17. Run the electrophoresis at $21 \mathrm{~V}$ for $20 \min$ at $4^{\circ} \mathrm{C}$.

18. Remove the slides from the tank, and immerse in distilled water ( 3 times), each time for $5 \mathrm{~min}$.

19. Fix the slides twice for $5 \mathrm{~min}$ in absolute ethanol. Leave to air dry.

20. For visualization, stain each sample with $20 \mu \mathrm{l}$ of DAPI $(1 \mu \mathrm{g} / \mathrm{ml})$ and observe using a fluorescence microscope. 
DNA damage evaluation

Evaluation of DNA damage is obtained by capturing at least 100 cells per sample, and process the image by using comet analysis software. The results should be expressed as percentage of DNA in the tail. 


\section{Western Blot}

Work solutions preparation
A. 1x PBS buffer

To obtain $1 \mathrm{~L}$ of PBS buffer solution:

- weigh all reagents necessary, according to the table below.

- dissolve in $800 \mathrm{ml}$ of ultrapure $\mathrm{H}_{2} \mathrm{O}$;

- $\quad$ adjust $\mathrm{pH}$ to 7.4 ;

- add ultrapure $\mathrm{H}_{2} \mathrm{O}$ to a final volume of $1 \mathrm{~L}$.

PBS buffer solution should be sterilized (autoclave) and then store at $4^{\circ} \mathrm{C}$.

\begin{tabular}{|r|r|c|}
\hline & Final concentration & Weight \\
\hline $\mathrm{NaCl}$ & $137.0 \mathrm{mM}$ & $8.0 \mathrm{~g}$ \\
\hline $\mathrm{Kcl}$ & $2.7 \mathrm{mM}$ & $0.20 \mathrm{~g}$ \\
\hline $\mathrm{Na}_{2} \mathrm{PO}_{4}$ & $10.0 \mathrm{mM}$ & $1.44 \mathrm{~g}$ \\
\hline $\mathrm{KH}_{2} \mathrm{PO}_{4}$ & $2.0 \mathrm{mM}$ & $0.24 \mathrm{~g}$ \\
\hline
\end{tabular}

B. RIPA buffer

\begin{tabular}{|c|c|c|c|}
\hline RIPA & PMSF & $\begin{array}{c}\text { Protease } \\
\text { inhibitor } \\
\text { cocktail }\end{array}$ & $\begin{array}{c}\text { Sodium } \\
\text { orthovanadate }\end{array}$ \\
\hline $1 \mathrm{ml}$ & $10 \mu \mathrm{l}$ & $10-20 \mu \mathrm{l}$ & $10 \mu \mathrm{l}$ \\
\hline
\end{tabular}

C. Running buffer

To obtain $700 \mathrm{ml}$ of running buffer add $70 \mathrm{ml}$ of tris-glycine buffer $10 x$ ( $25 \mathrm{mM}$ of tris base and $192 \mu \mathrm{M}$ of glycine) with $7 \mathrm{ml}$ SDS 10x (0,1\% SDS). Add distilled water until $700 \mathrm{ml}$ and stir. Check the $\mathrm{pH}$ and adjust to 8.3 if necessary and then store at $4^{\circ} \mathrm{C}$. 
D. TPBS buffer

To obtain TPBS buffer add $1 \mathrm{ml}$ of Tween $20(0.1 \%)$ on $1 \mathrm{~L}$ of PBS.

E. Blocking solution

Add $1 \mathrm{~g}$ of dry milk into $20 \mathrm{ml}$ of TPBS.

F. Relevation solution

Mix $400 \mathrm{ml}$ of Peroxide solution with $400 \mathrm{ml}$ of Luminol/enhancer solution.

\section{Procedure}

(Incubation at $37^{\circ} \mathrm{C}$ with $5 \%$ of $\mathrm{CO}_{2}$ )

\section{Sample preparation}

1. Plate cells in a 6 -multiwell culture plate with a final volume of $2 \mathrm{ml} /$ well, respecting the appropriate cellular density for each cell line. Cells should be incubated for $24 \mathrm{~h}$ to promote cell adhesion.

2. Incubate the cells with the respective treatment.

3. When completed the incubation time, discard the medium from each well and wash with PBS (1x).

4. From this point forward the cells must be kept on ice.

5. Add 100 or $200 \mu \mathrm{l}$ (depending on cell density) of ice-cold RIPA buffer and incubate for $10 \mathrm{~min}$.

6. Scrape adherent cells off the dish and transfer the cell suspension into a pre-cooled microcentrifuge tube.

7. Centrifuge cells for $10 \mathrm{~min}$ at $10000 \mathrm{~g}$, in a $4^{\circ} \mathrm{C}$ pre-cooled centrifuge.

8. Gently remove the centrifuge tube and place it on ice. Transfer the supernatant to a new tube and discard the pellet.

9. Remove 10-20 $\mu \mathrm{l}$ of lysate to perform a protein assay (BCA method). 
10. If desired, store protein samples at $-20^{\circ} \mathrm{C}$.

Protein separation by gel electrophoresis

Mini protean tetra system tank (Bio-Rad)

1. Assemble the TGX precastgel system and add the running buffer.

2. Load equal amounts of protein $(60 \mu \mathrm{g})$ into the wells of a Miniprotean TGX 4$20 \%$. In the first well load $4 \mu \mathrm{l}$ of migration of precision plus protein westernC Standards.

3. Run the gel for about $45 \mathrm{~min}$ at $150 \mathrm{~W}$.

Transfering the protein to the membrane

Transblot $\circledast$ turbo ${ }^{\mathrm{TM}}$ transfer system

1. Remove the gel and wash three times with TPBS buffer (for 5, 10 and 15 $\min )$.

2. Assemble the transfer sandwich. The membrane (0.2 $\mu \mathrm{M}$ PVDF) should be on the anode and the gel on the cathode.

3. Place the cassettes in the Trans-Blot Turbo Transfer System.

4. Transfer at a constant current of $2.5 \mathrm{~A}, 25 \mathrm{~W}$ for $7 \mathrm{~min}$.

5. Wash the membrane three times with TPBS. If desired, dry the membrane and store at $4^{\circ} \mathrm{C}$ or do the block.

\section{Antibody incubation}

1. Leave the membrane in the blocking solution for 2 hours, at room temperature.

2. Wash the membrane three times with TPBS.

3. Incubate with the primary antibody solution, overnight at $4^{\circ} \mathrm{C}$ with diagonal agitation.

4. Wash the membrane three times with TPBS.

5. Incubate with the secondary antibody solution for $1 \mathrm{~h}$, at room temperature. The antibody can be diluted using $5 \%$ skim milk in TPBS. 
6. Wash the membrane three times with TPBS.

Imaging and data analysis

1. Cover the membrane with the revelation solution.

2. Incubate for $1 \mathrm{~min}$ at room temperature.

3. Capture the chemiluminescent signals using a chemiluminescence detection system and quantify the band intensity with appropriate software. 